مجلة كلية التربية، جامعة الأزهر، العدد: ( 14 الجزء الأول) يوليو لسنة ه 1 ـ بام

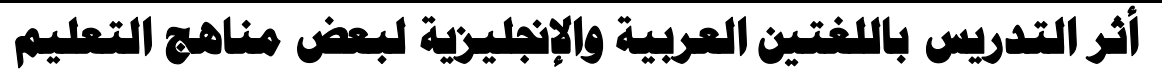 \\ في القيم الأخلاقية لمطلاب المرهلة الثمانوية \\ بالمماكة العربية السمعودية
}

\section{ملخص بحث:}

استهدف البحث الاستقصاء التقييمي لتأثير تعليم بعض المنــاهج الدراسـية بـاللغتين

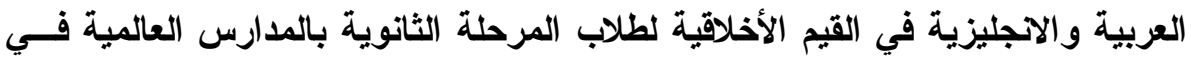
جدة. وذلك سعيًا إلى الإجابة عن الأسئلة الأيلة التالية:

ا. ما آراء المعلمين والمشرفين التربويين والمدراء حول أثر التعليم باللغتين العربية

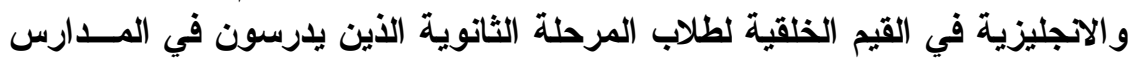

$$
\text { العالميةّ؟ }
$$

r. ما آراء المعلمين والمشرفين التربويين والمدراء حول أثر التعليم باللغتين العربية

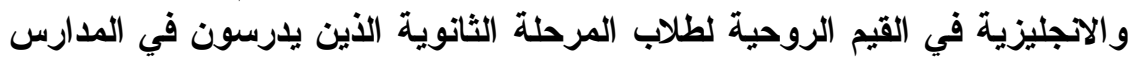

r. ما آراء المعلمين والمشرفين التربويين والمدراء حول أثر التعليم باللغتين العربية

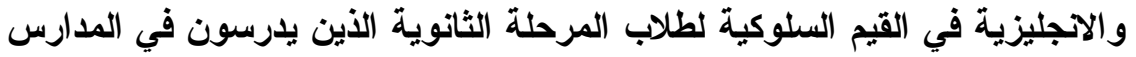

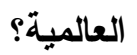

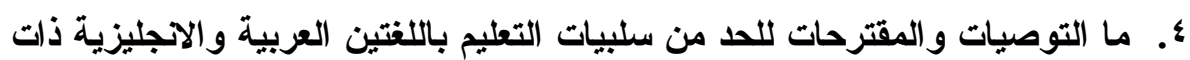

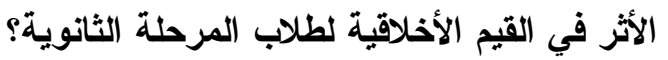

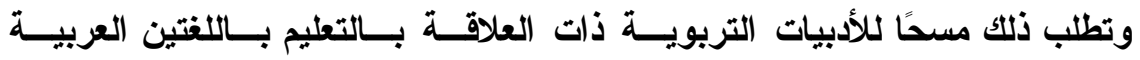

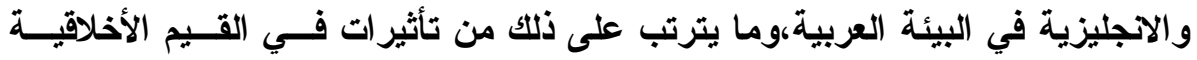

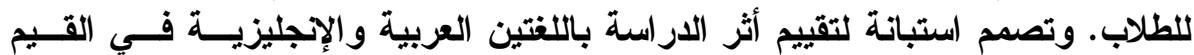

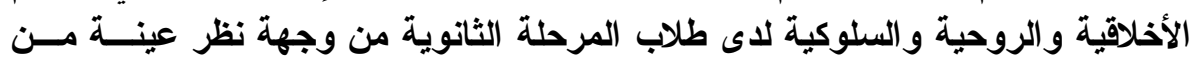
المعلمين والمشرفين التربويين والمدراء في المدارس العالمية بجدة

وأوضحت النتائج أن محصلة تقييم مستوى التزام طلاب المدارس الثانوية العالمية

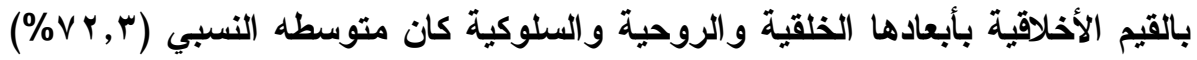
وهي نسبة متوسطة،

وجاءت في الترتيب الأول مؤشرات القيم السلوكية للانتماء للادين و الوطن واللغـــة

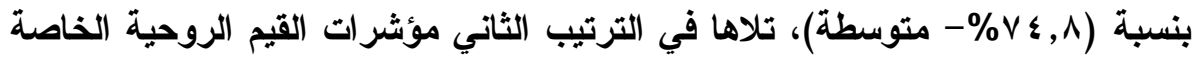


مجلة كلية التربية، جامعة الأزهر، العدد: (ع 1 الجزء الأول) يوليو لسنة 1 ـ ب م

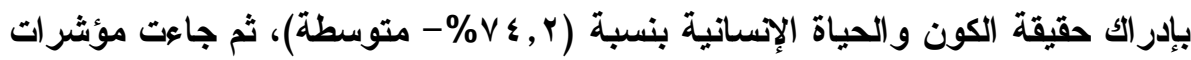

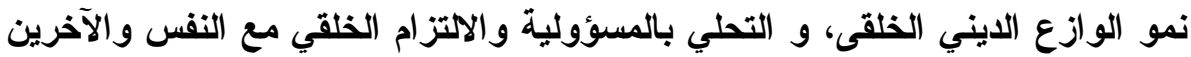

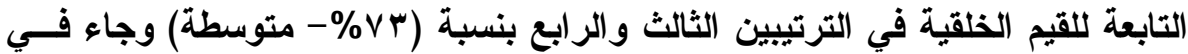

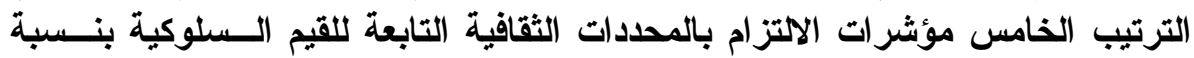

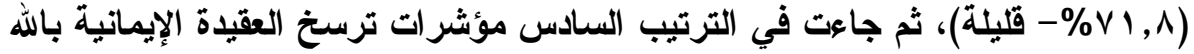

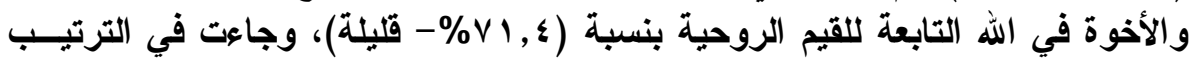

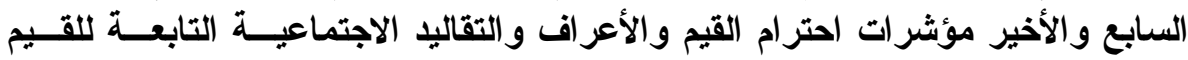

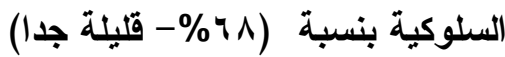

واختتم البحث بعدد (Y^)توصية مقترحة لتعميق أثر التعليم باللغة العربية في تنمية

القيم الأخلاقية لاى طلاب المرحلة الثانوية الذين يدرسون باللغتين العربية والإنجليزية

في المدارس العالمية.

\section{Summary}

Find targeted evaluation survey of the impact of some of the education curriculum in Arabic and English in the moral values of students at the secondary school phase of the World in Jeddah. In an effort to answer the following questions:

1. What the views of teachers, supervisors and managers about the impact of education in Arabic and English in the moral values of the high school students who are studying in international schools?

2. What the views of teachers, supervisors and managers about the impact of education in Arabic and English in the spiritual values of the high school students who are studying in international schools?

3. What the views of teachers, supervisors and managers about the impact of education in Arabic and English in behavioral values for high school students who are studying in international schools?

4. What recommendations and proposals to limit the negative aspects of education in Arabic and English with effect in the moral values of high school students?

And requests that a survey of the educational literature related to education in English and Arabic in the Arab environment, and the consequent effects in the moral values of students. And a questionnaire designed to assess the impact study in Arabic and English in the moral, spiritual and behavioral values among high 


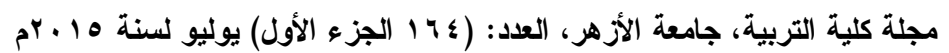

school from a sample of teachers, supervisors and managers in international schools in Jeddah consider students

The results showed that the outcome of the evaluation of the level of global high school students ethical values, moral and spiritual dimensions and behavioral commitment to the relative average $(72.3 \%)$, the proportion of medium,

And came in first place behavioral values to belong to the religion and the homeland, language indicators by $(74.8 \%$ - medium), followed in second place spirituality own to realize the truth of the universe and human life by indicators $(74.2 \%$ - medium), and then came the religious faith of moral growth indicators, and exercise responsibility moral and commitment with oneself and others of moral values in the two arrangements third and fourth rate (73\% - medium) and came in fifth respectively commitment to cultural determinants of behavioral values of indicators by $(71.8 \%$ - a few), and then came in the sixth ranking indicators established faith of belief in God and the brotherhood God in the spiritual values by (71.4\% - a few), and came in the seventh and final arrangement respecting the values and social norms and traditions of the behavioral indicators values by $(68 \%$ - very few)

He concluded Find the number $(28)$ recommendation proposed to deepen the impact of education in Arabic in the development of moral values among high school students who are studying Arabic and English in international schools 
يتسم العصر الذي نعيشه بتعدد لغات التعليم، وذلك في ظل الانفتاح العالمي الذي لئي

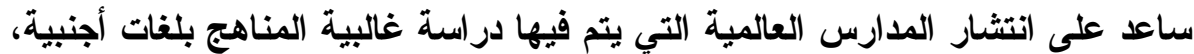

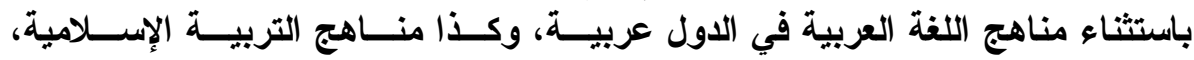

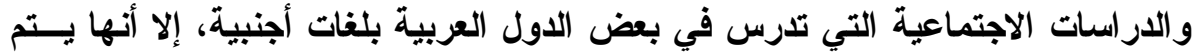

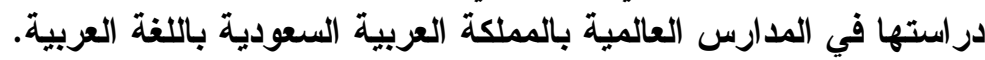

ونظرا لأن اللغة هي وعاء الفكر، فقد تناولت العديد من الأدبيات التأثيرات المترتبة

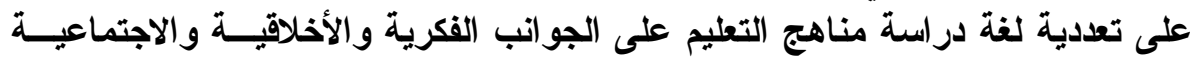

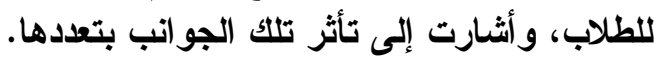

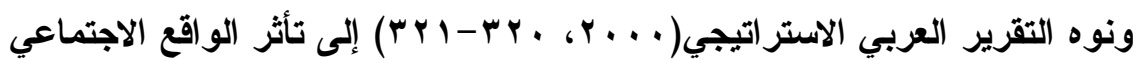

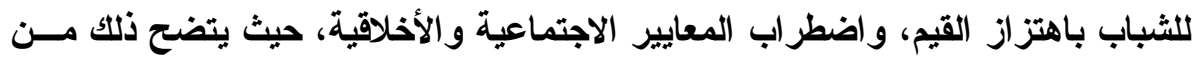

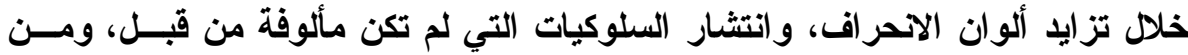

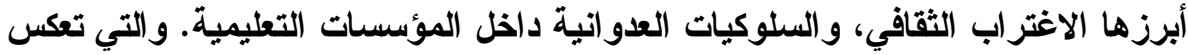
محدودية أثر المناهج التعليمية في تنمية القيم الأخلاقية الضابطة لسلوكيات المتعلمين.

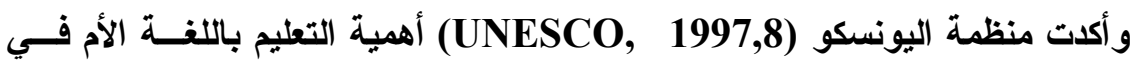

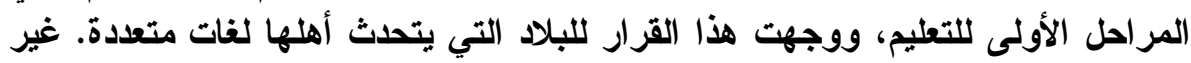

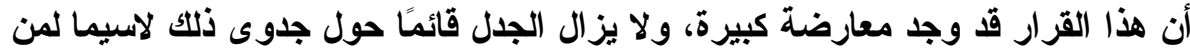
لا يواصل تعليمه بلفته الأم في المراحل الحل الأعلى.

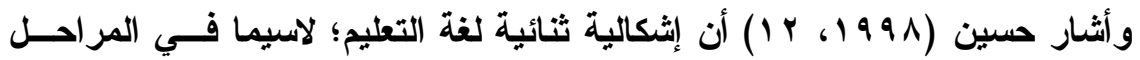

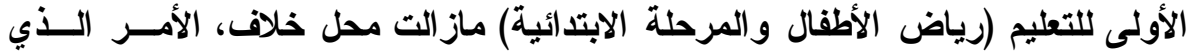

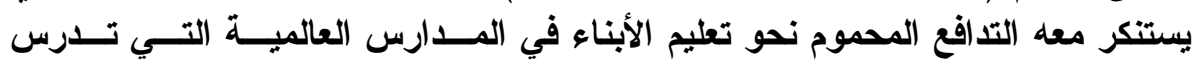
مناهجها بلغات أجنبية.

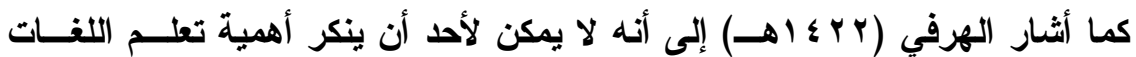

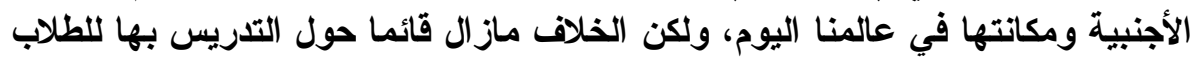

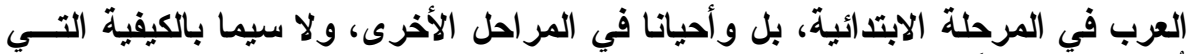
تُدرس بها حالياً.

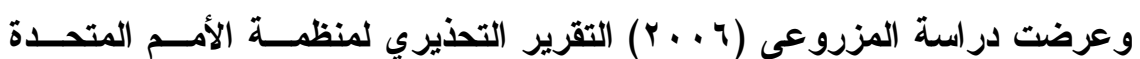

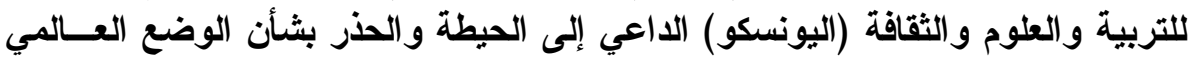

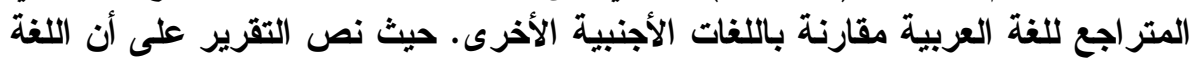


مجلة كلية التربية، جامعة الأزهر، العدد: (ع 11 الجزء الأول) يوليو لسنة 1 1 ب بم

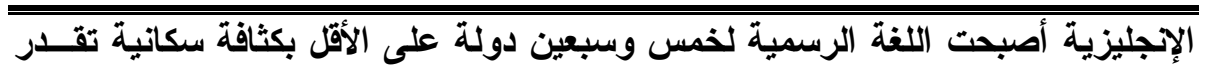

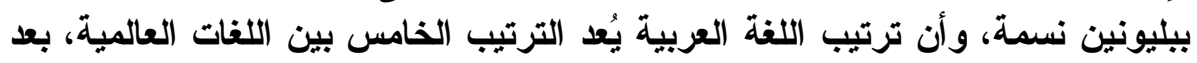
أن كانت العربية تحتل الترتيب الر ابع إلى عهد قريب.

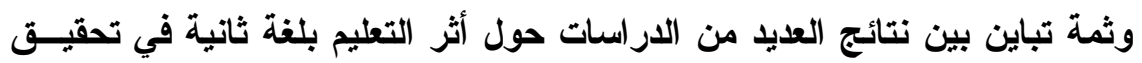

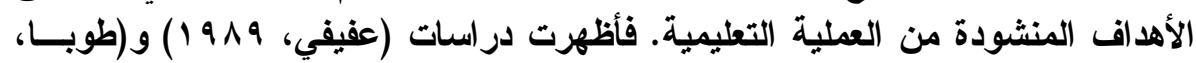

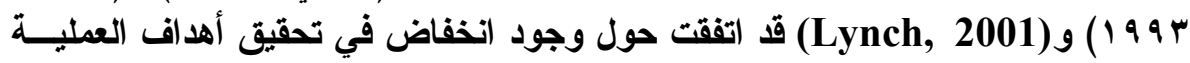

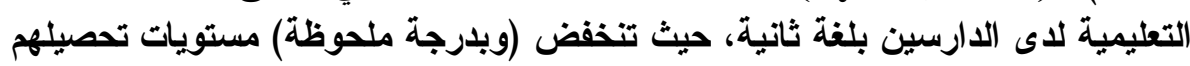

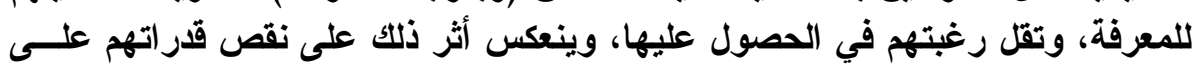

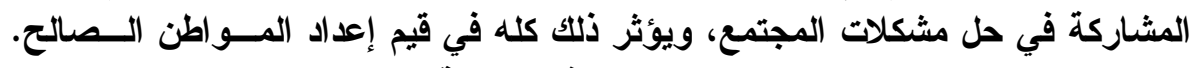

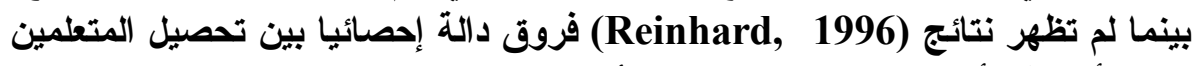
بلغات أجنبية وأقرانهم المتعلمين بلغتهم الأم.

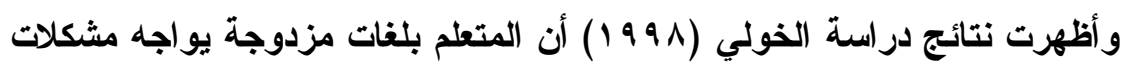

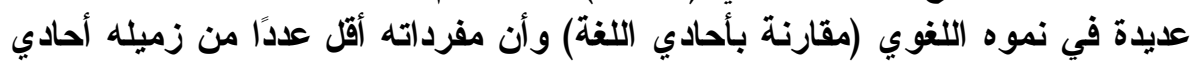

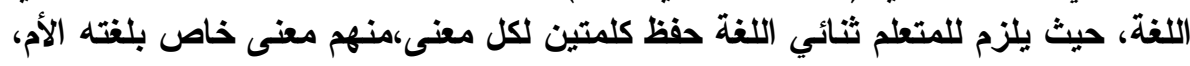

ومعنى خاص باللغة الأخرى التي يتعلم بها.

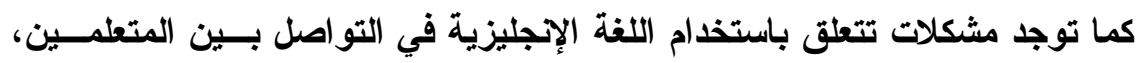

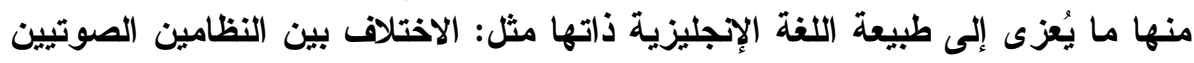

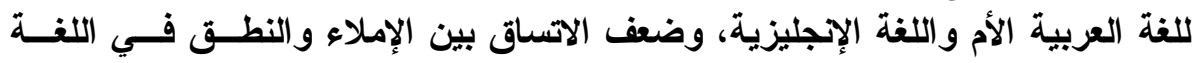

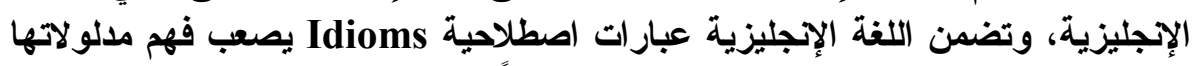

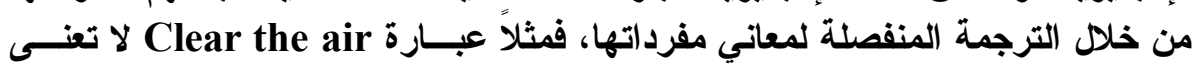
"تنظيف الهواء"، (Hornby,Cowie and Gimson, 1984, 280).

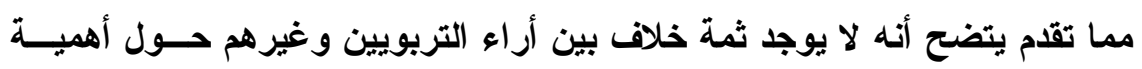

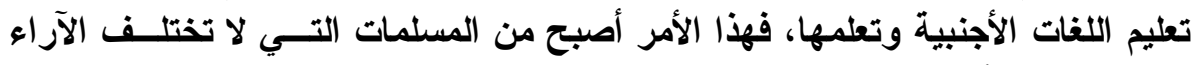

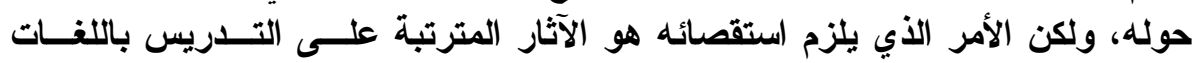
الأجنبية في القيم الأخلاقية للمتعلمين: الألمائ

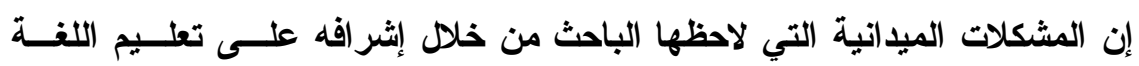

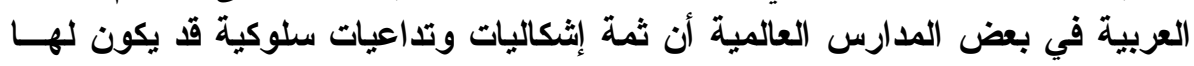

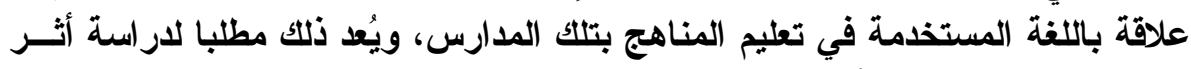

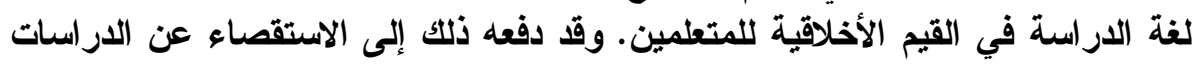

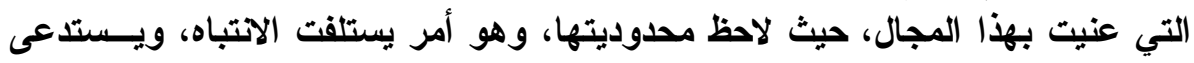

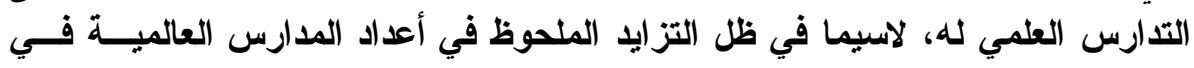




$$
\text { المملكة العربية السعودية. }
$$

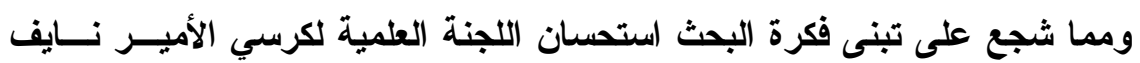

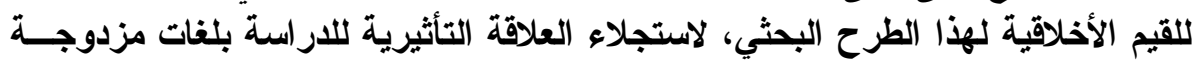

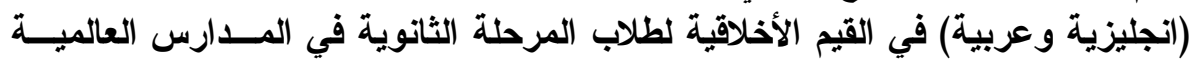

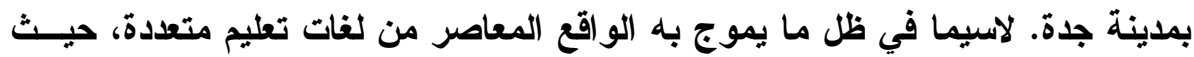

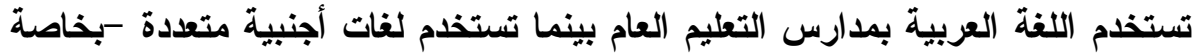

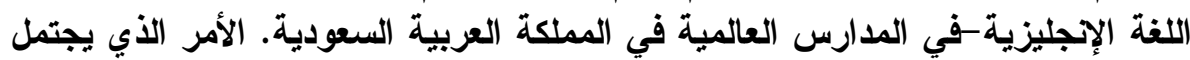

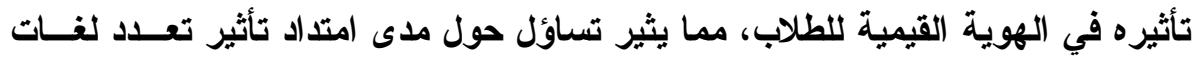

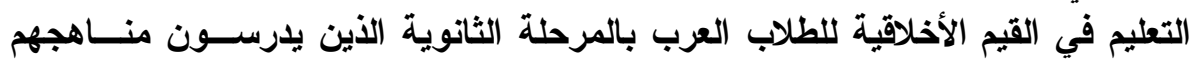

$$
\text { باللغتين العربية والانجليزية؟ الاخلية }
$$

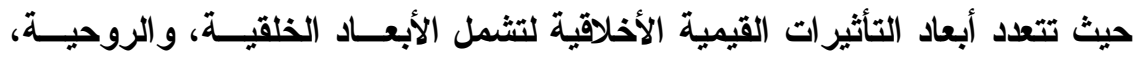

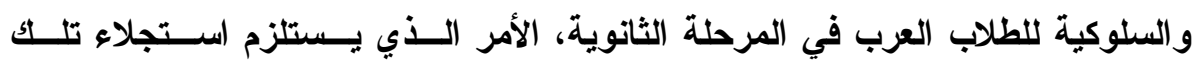

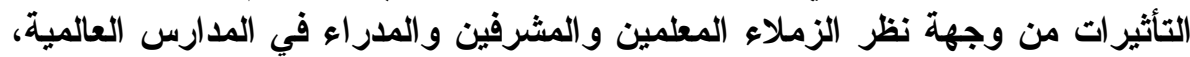

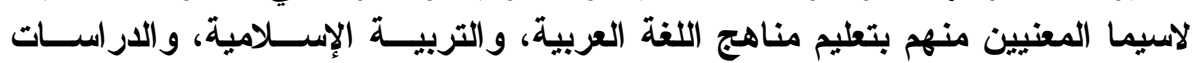
الاجتماعيات بالمدارس العالمية أولا: مشكلة البحث

في ضوء جميع ما تقدم تبلورت مشكلة البحث في سؤال رئيس هو:

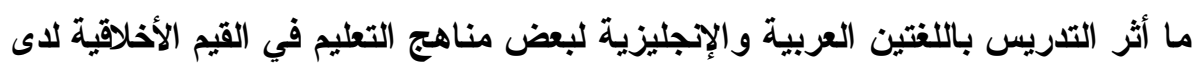

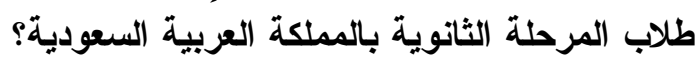

وتتطلب الإجابة عن هذا السؤال الرئيس إجابة الأسئلة الفرعية التالية: ا. . ما آراء المعلمين والمشرفين التربويين والمدراء حول أثر التعليم باللغتين العربية

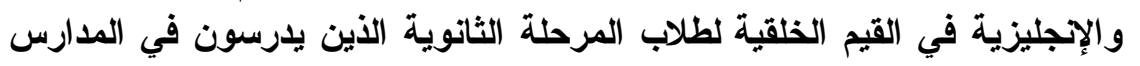
العالميةّ؟ r. ما آراء المعلمين والمشرفين التربويين والمدراء حول أثر التعليم باللغتين العربية

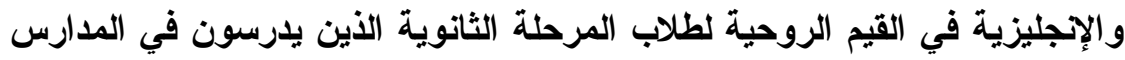
العالميةّ؟ r. ما آراء المعلمين والمشرفين التربويين والمدراء حول أثر التعليم باللغتين العربية

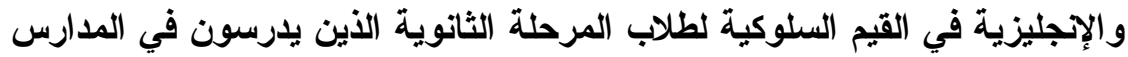




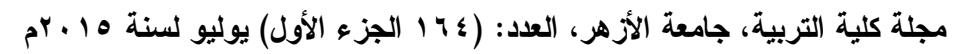

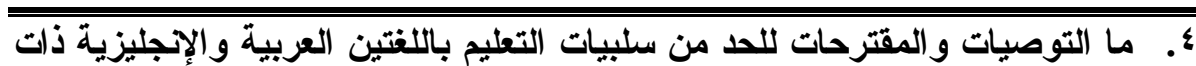

الأثر في القيم الأخلاقية لطلاب المرحلة الثانوية؛

$$
\text { ثانيا: أهداف البحث }
$$

يستهذف البحث تحقيق ما يلي:

ا ـ بيان آراء المعلمين والمشرفين التزبويين والمدراء حول أثر التعليم باللغتين العربية

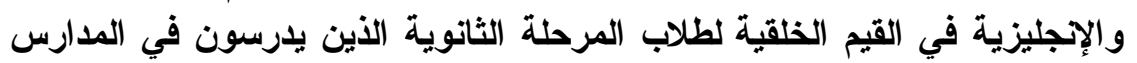

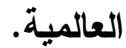

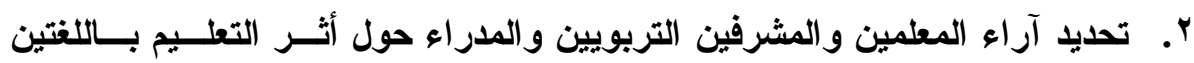

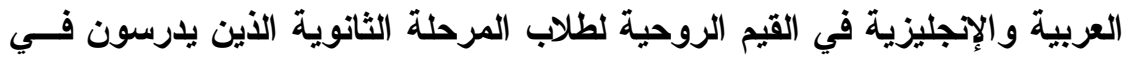

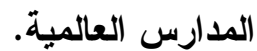

r. ت توضيح آراء المعلمين والمشرفين التربويين والمدراء حول أثر التعلـيم بــاللغتين

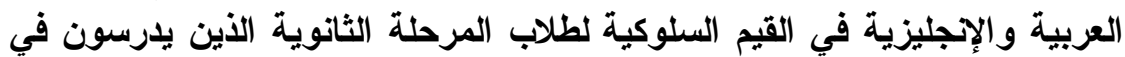

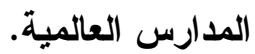

؛. . تقايم التوصيات والمقترحات للحد من سلبيات التعليم باللغتين العربية والإبليزية ذات الأثر في القيم الأخلاقية لطلاب المرحلة الثانوية؟

ثالثا: أهمبة البحث

من المتوقع أن يفيد البحث في تحقيق ما يلي:

1. التقييم الموضوعي للتأثير ات القيمية الأخلاقية المترتبة على التعليم باللغتين العربية

والإنجليزية لاى طلاب المرحلة الثاتوية في المملكة العربية السعودية.

r. تقديم أداة علمية مضبوطة يمكن أن تفيد الباحثين في مجال تقييم أثر التعليم باللغات

العربية والأجنبية في القيم الأخلاقية لطلاب المبلية المرحلة الثاتوية.

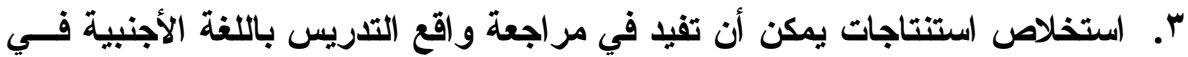

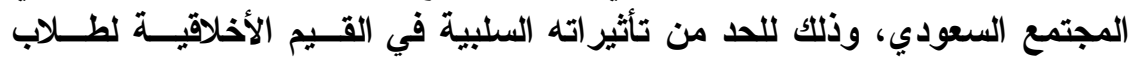

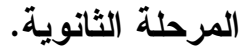

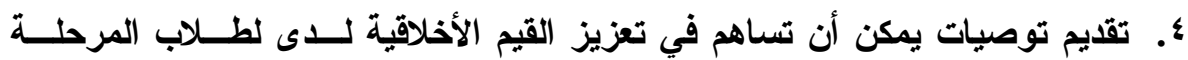

الثانوية الدارسين باللغتين العربية وان والاتجليزية. 
رابعا: المخرجات المتوقعة للبحث:

$$
\text { من المخرجات المتوقعة للبحث ما يلي: }
$$

1- توفير نتائج موضوعية لتأثثر التعليم باللغات الأجنبية في القيم الأخلاقية لاي طلاب

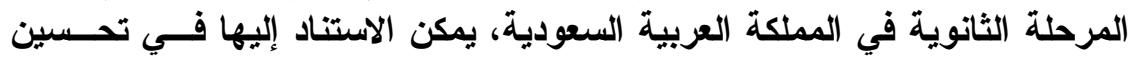
واقع التعليم باللغات الأجنبية في المدارس العبلة العابلمية.

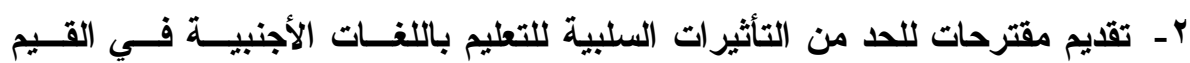

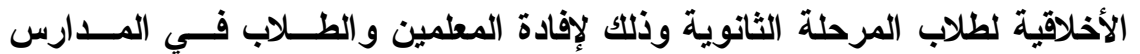

العالمبة.

r- تبصير المعلمين والطلاب وأولياء الأمور بمعايير القيم الأخلاقية ومؤشر اتها التــي

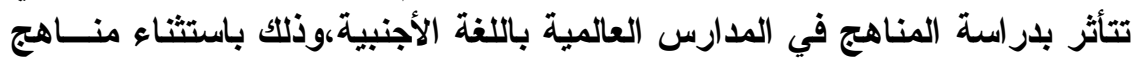

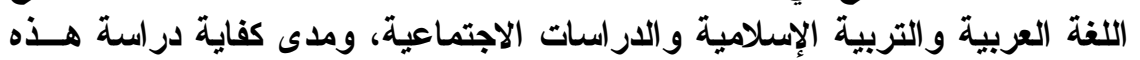

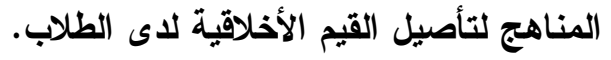

خامسا: مصطلحات البحث

1-التدريس Teaching.

يستخدم مصطلح التدريس للالالة على العمليات التي يقوم بها المعلم مع المتعلمين

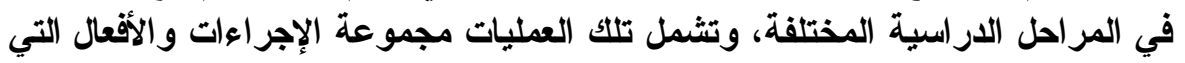

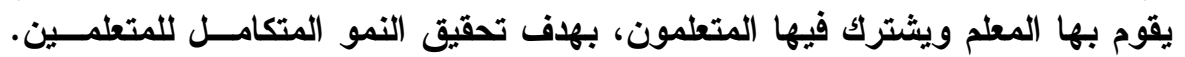

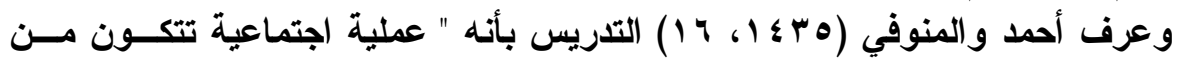

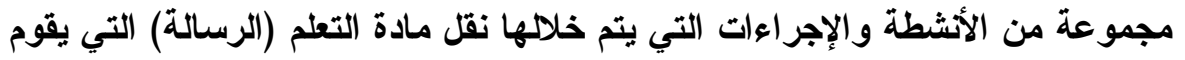

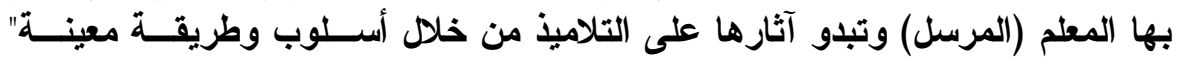
ويتسق هذا التعريف مع المقصود بمفهوم التدريس في البحث الحئ الحالي.

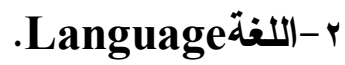

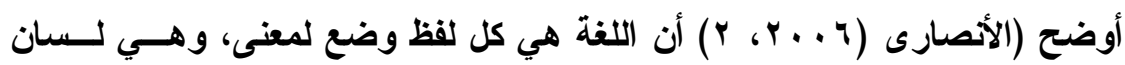

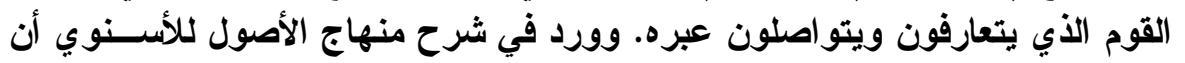

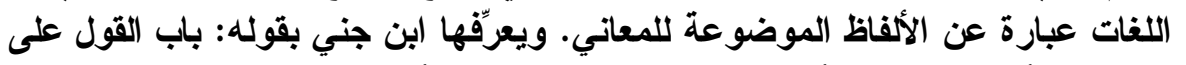

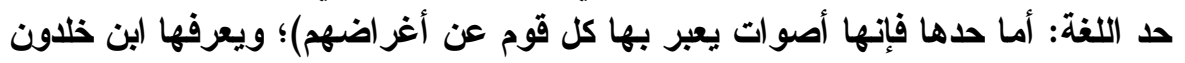

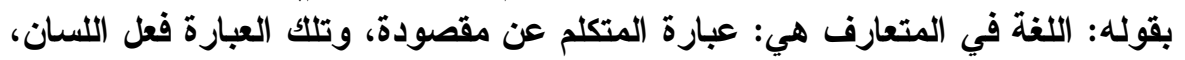

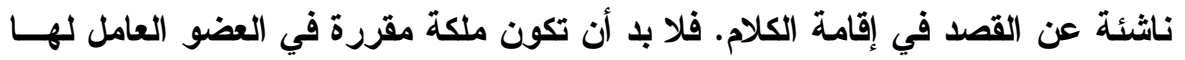

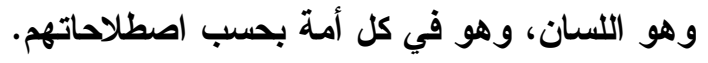

$-\varepsilon r \cdot-$ 


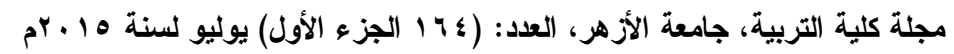

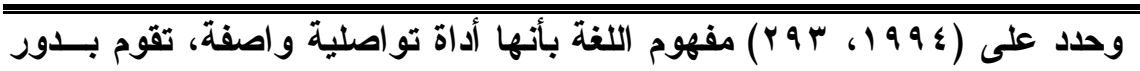

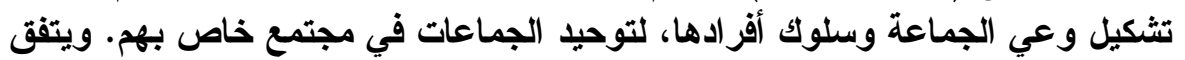
هذا المفهوم مع المقصود باللغة في الدراعة وسلة الحالية.

r-اللغات الأجنبية Foreign Languages.

أثنار Hornby,Cowie and Gimson (1984, 278

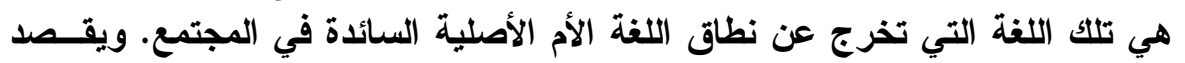

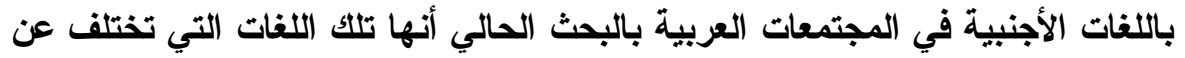

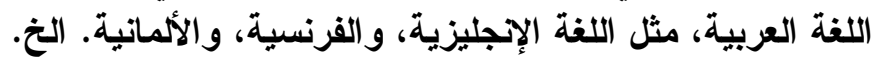

ع - القيم Values

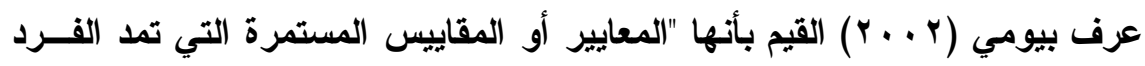

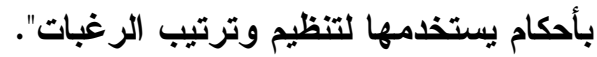

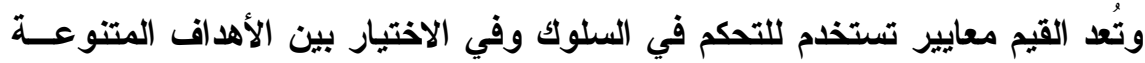

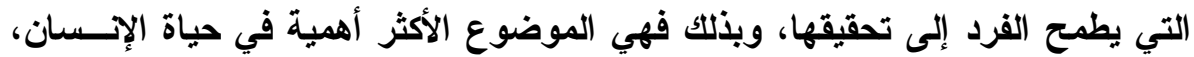
وعلى ضوئها يتم الحكم على سلامة سلوكه و استقامته أو انحر افهـ.

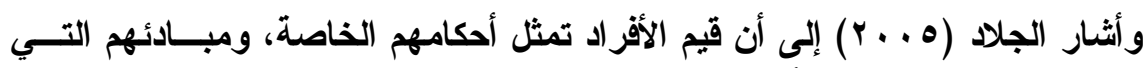

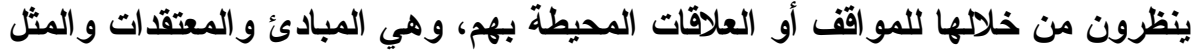
و المقاييس التي تعمل مرشدا عاما للسلوك، أو نقاط تفضيل في صنع القرارئ وارئ أو لتقويم المعتقات و الأفعال

ه-القيم الأخلاقية Ethical Values.

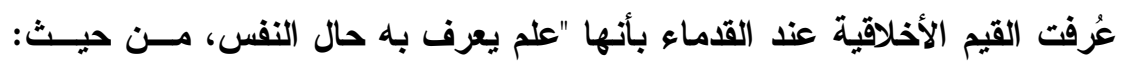

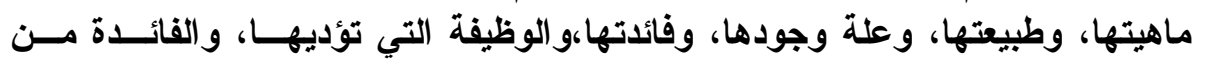

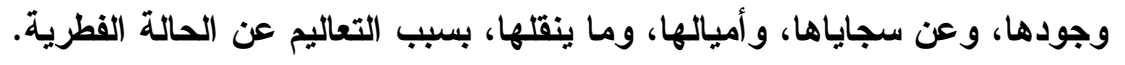

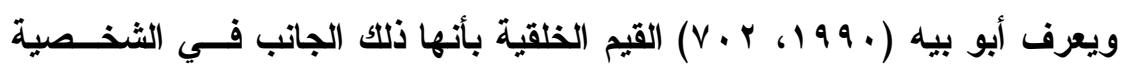

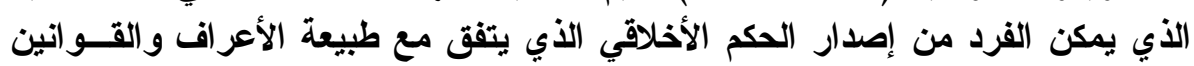

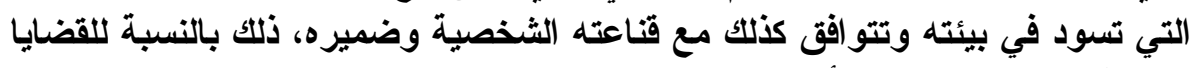

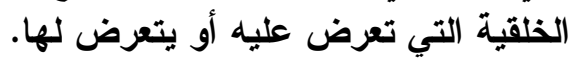

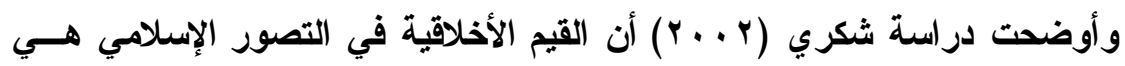

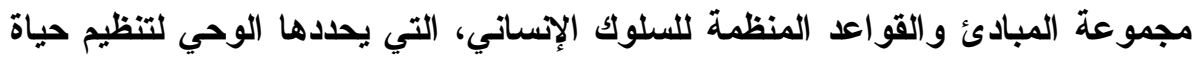

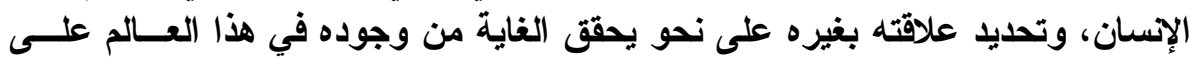


أكمل وجه. أي أنها مجموع الأخلاق التي تصنع نسيج الشخصية الإسلامية، وتجعلهـ ألـا

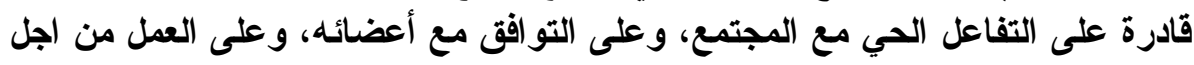

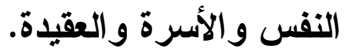

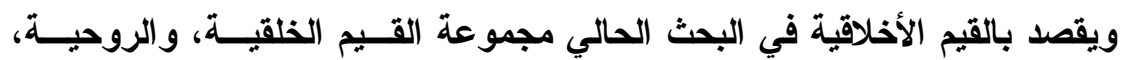

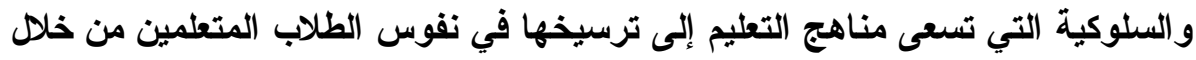

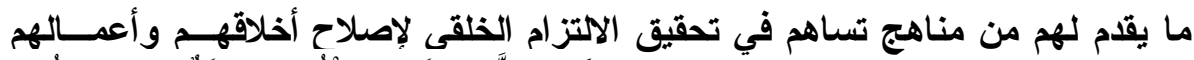

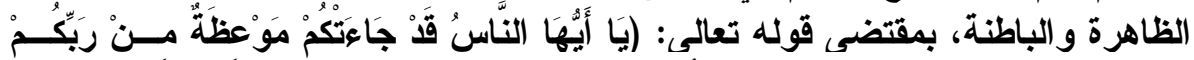

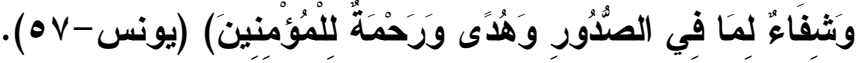

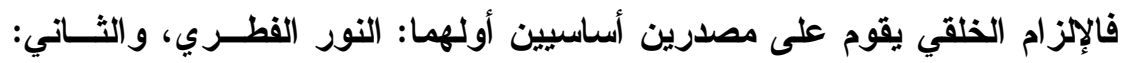

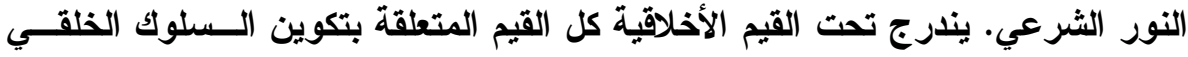

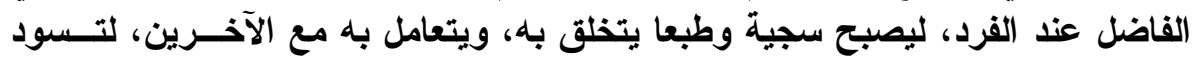

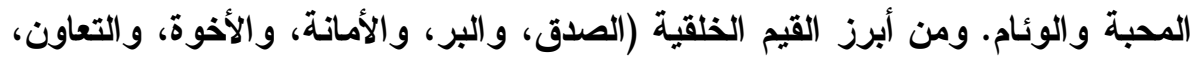

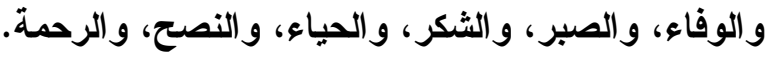

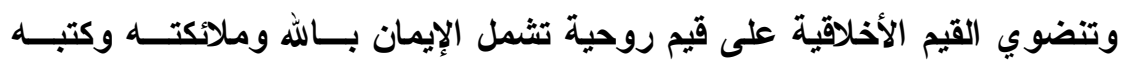

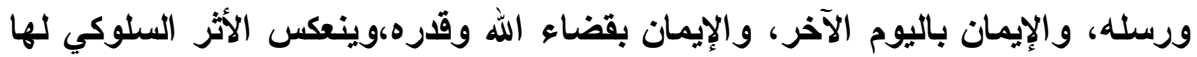

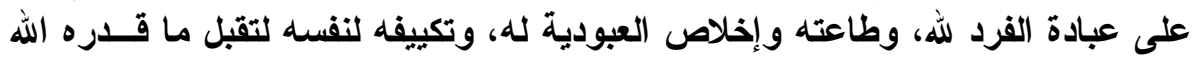

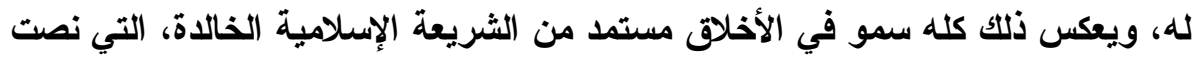

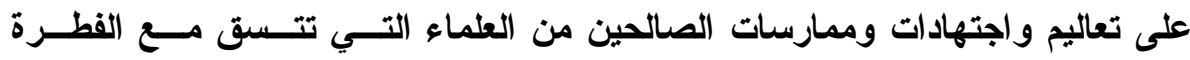

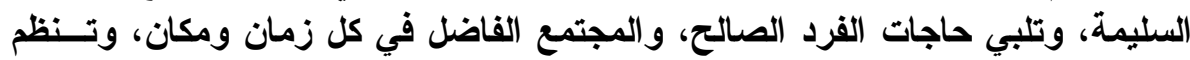

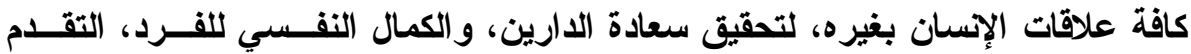

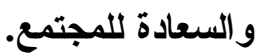

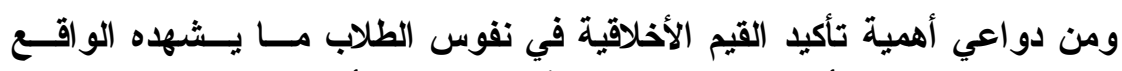

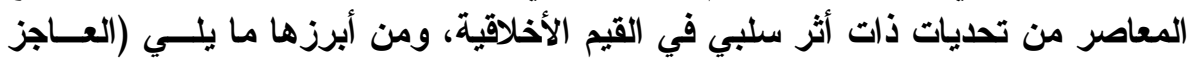

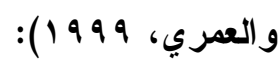

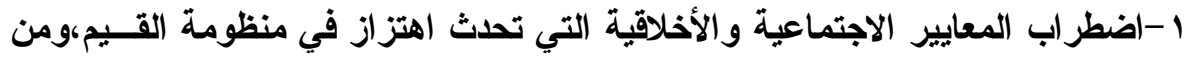

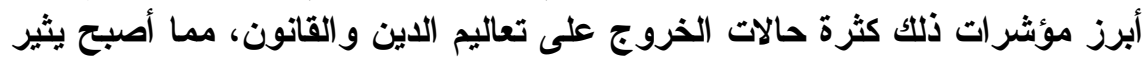

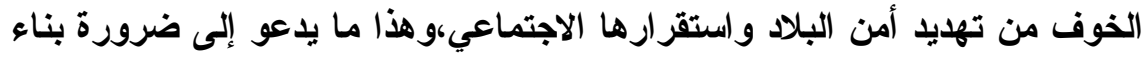

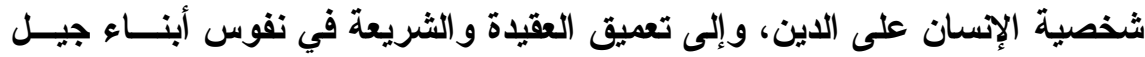

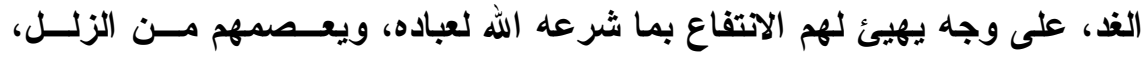

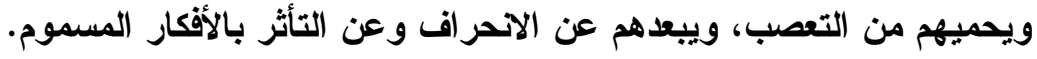




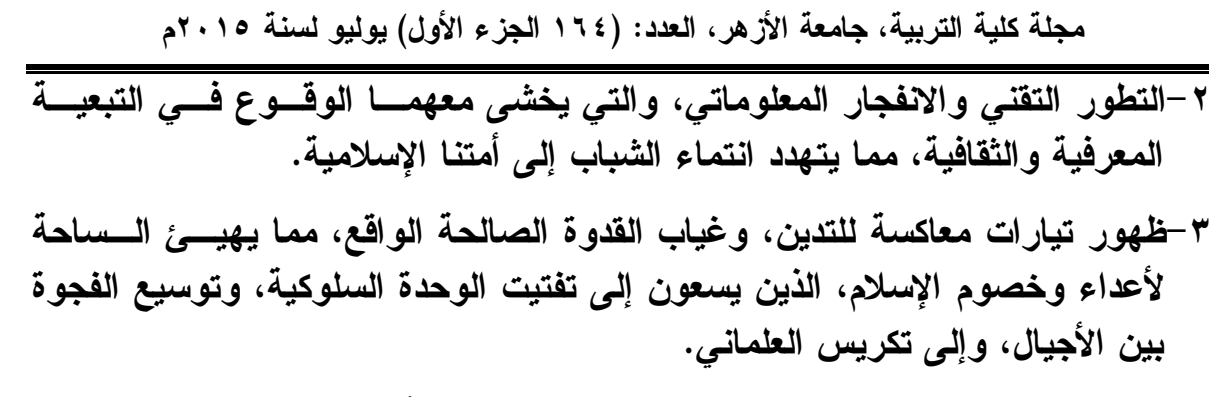

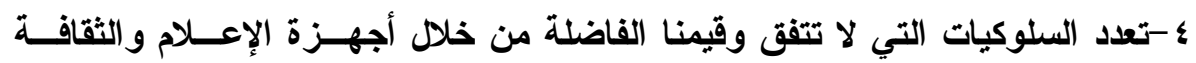

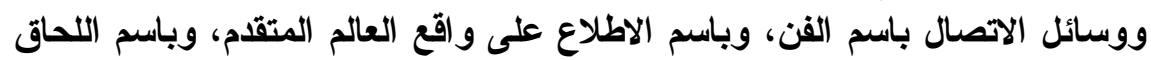

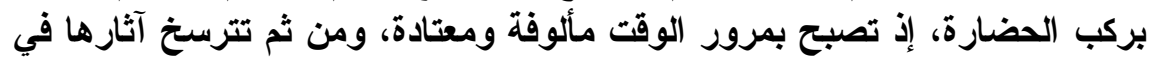
النفوس وتزلزل القيم الدينية بالاعتياد عليه.

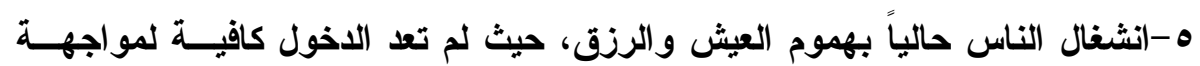

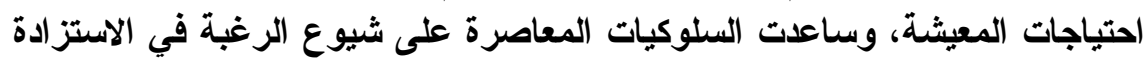

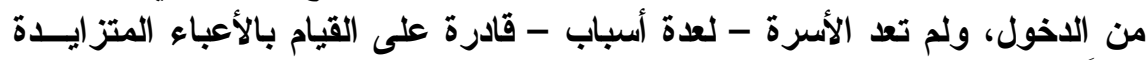

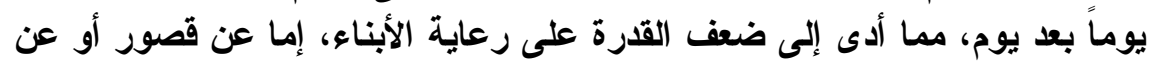
تقصير.

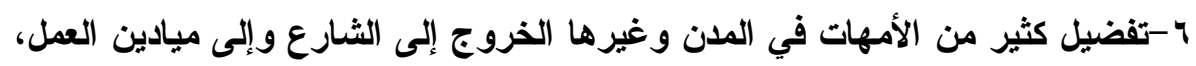

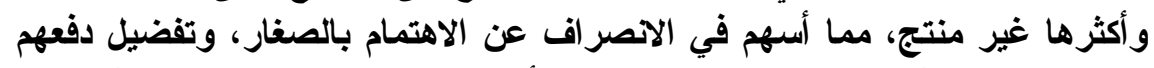
إلى دور الحضانة وبيوت الجيران وغيرهم، فأصبح البيت على هامش الانص التربية.

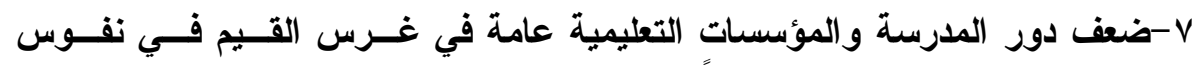

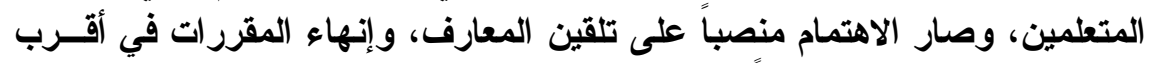

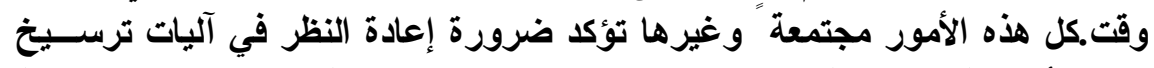

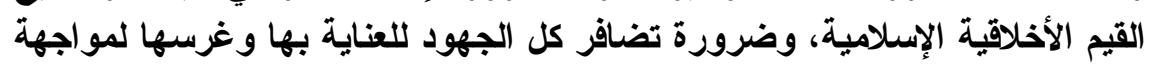
هذه التحديات المجتمعية المعاصرة.

$$
\begin{aligned}
& \text { سادسا: حدود البحث } \\
& \text { التزم البحث الحدود التالية: }
\end{aligned}
$$

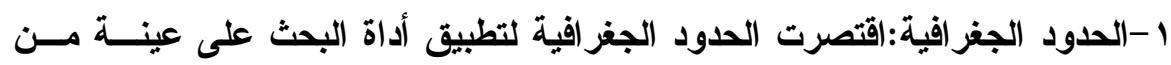

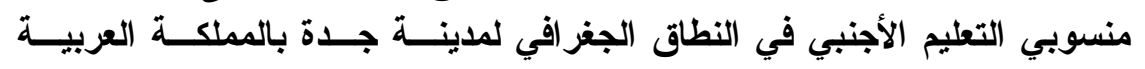
السعودية.

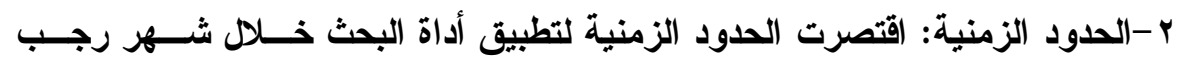
צr \& اهو،وهي الفترة التي تم توزيع الأداة وتجميعها خلالهها. 
سابعا: منهجية تنفيذ البحث وفق جدوله الزمني. لتحقيق أهداف البحث تم اتباع الخطوات المنهجية التالية:

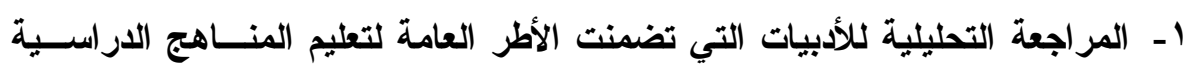
باللغات الأجنبية والعربية وتأثيراتها في القيم الأخلاقية للطلاب.

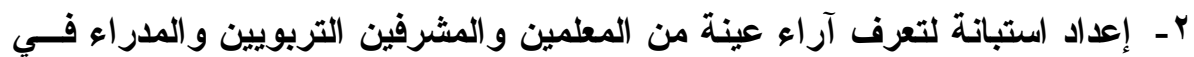

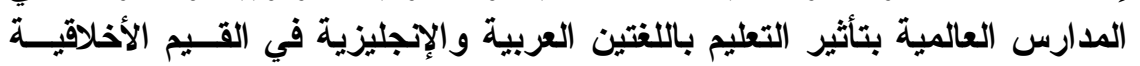

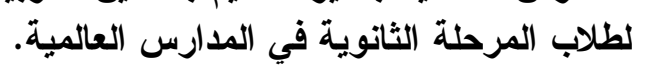

r- ت تطبيق الاستبانة على عينة البحث، ومعالجة النتائج إحصائيا للإجابة عن أسئلته.

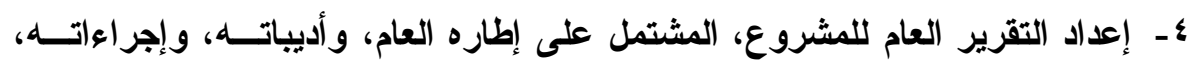
ونتائجه، وتوصياته. هـ تقليم المشروع إلى مسئولي كرسي الأمير نايف للقيم الأخلاقية، وإجراء ما يـــزم من ملاحظات.

ד- إخراج المشروع في صورته النهائية، مرفق معه إفادة قبوله في أحد أوعية النشر.

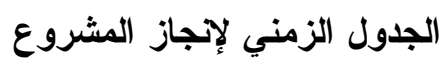

\begin{tabular}{|c|c|c|c|c|c|}
\hline \multicolumn{4}{|c|}{ (المدة بالثهــور) } & |الباحث & \multirow{2}{*}{ المهـــــــــــــــام } \\
\hline$\varepsilon$ & $r$ & r & 1 & & \\
\hline & & & $\checkmark$ & $\checkmark$ & 1. المسح المعلوماتي للأدبيات ذات العلاقةة بالمشروع \\
\hline & & $\checkmark$ & & $\checkmark$ & ل·.إعداد استباتة وضبطها، وتطبيقها على عينة المشروع \\
\hline & $\checkmark$ & & & & |". رصياغة البيانوص، ومعالجتها إحصائيا، ومناقثة النتائجة| \\
\hline$\checkmark$ & & & & $\checkmark$ & |؛. إعلداد التقزير النهائي للمشروع وتقايمه بعد اسـتيفاء| \\
\hline
\end{tabular}




\section{ثانيا: أدبيات البحث}

يتناول هذا القسم من البحث بعض الأدبيات ذات العلاقة بمتغيراته المدروسة، والتي

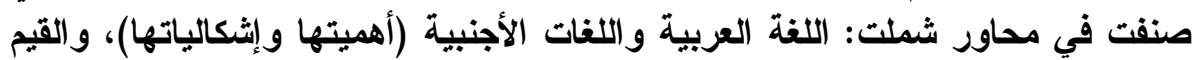

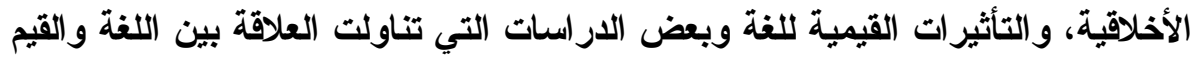

أولا: اللغة العربية واللغات الأجنبية(أهميتها و إثكالياتها). تُعد اللفة وعاء التواصل بين الأفزراد والمجتمعات، لذا تحرص المجتمعات المعاصرة

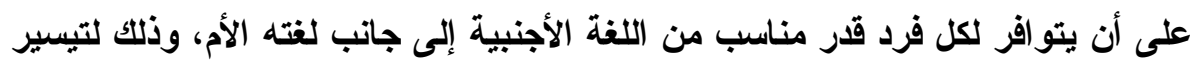

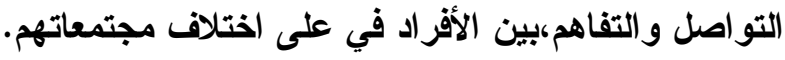

فاللغة أداة التفكير، و الوسيلة التي يستخدمها الناس في حديثهم وكتاباتهم واتصال

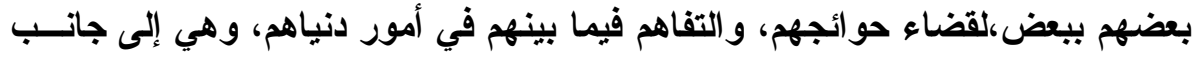

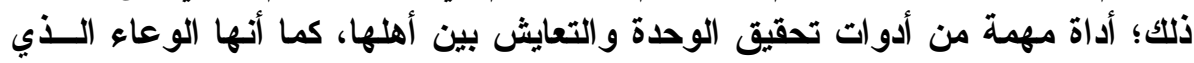

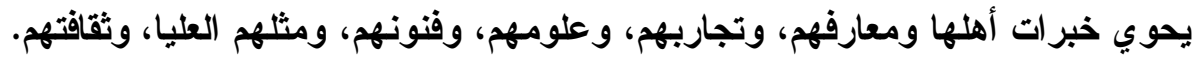

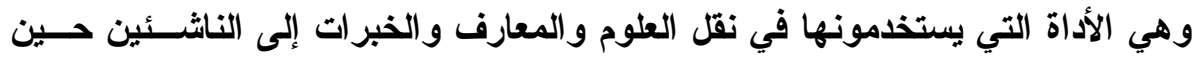

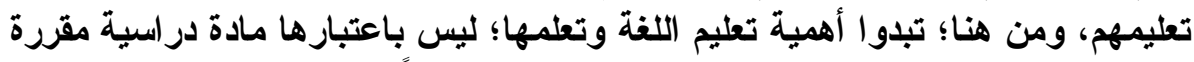

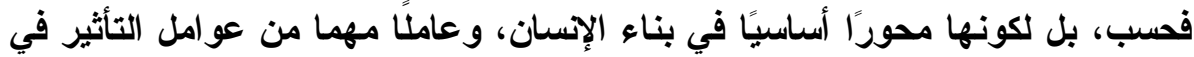
ثقاقته، وقيمه العلمية، والاجتماعية، ورئا والأخلاقية.

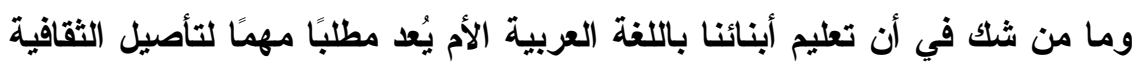

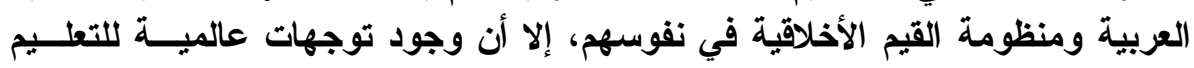

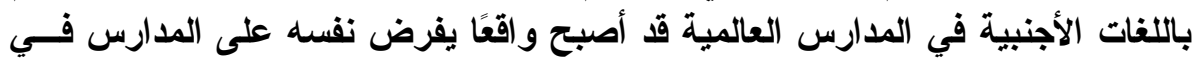

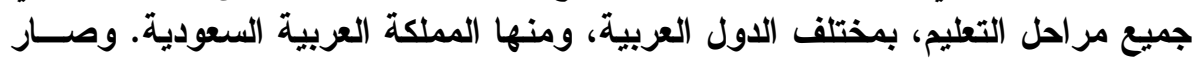

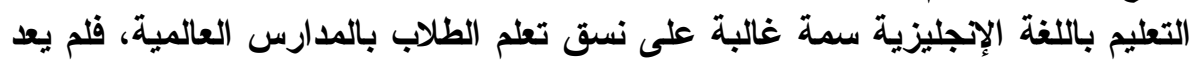

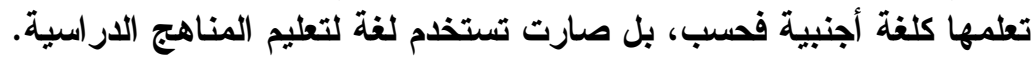

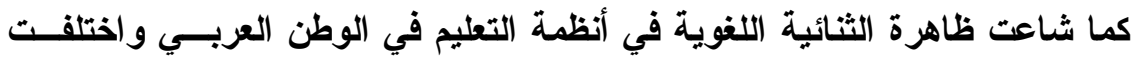

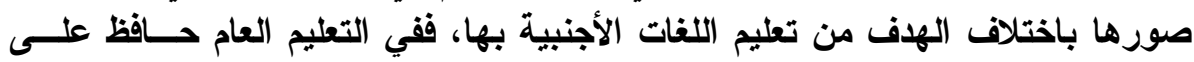

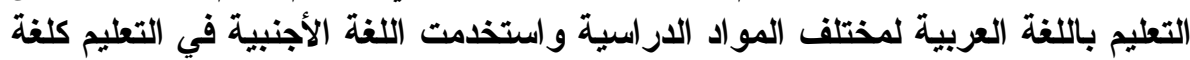

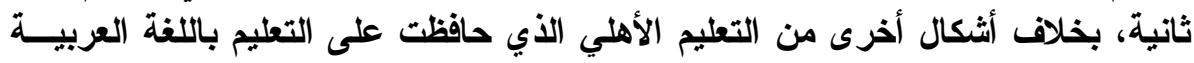

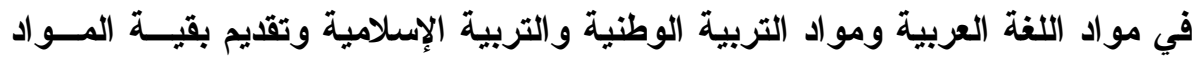

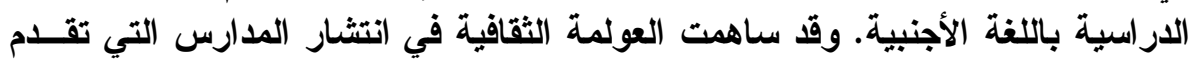

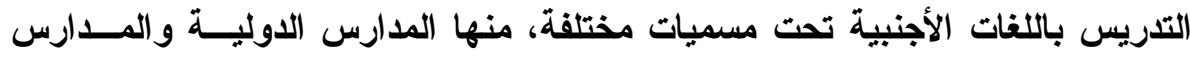
العالمية، بل إن بعض الدول قدمت في تعليمها أثنكالا للتدريس باللفات منات الأجنبية في معظم 
المواد الاراسية بمسميات مناهج مدارس اللغات الأجنبية.

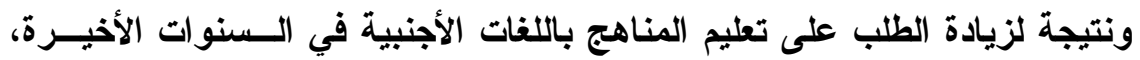
و التحاق أعداد كثيرة بالمدارس الأهلية التي تقوم بتعليم المناهج الدولية باللغات الأجنبية

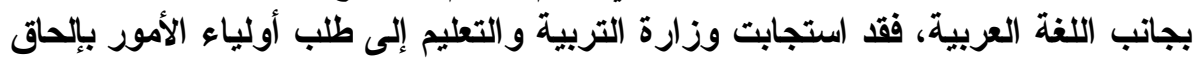

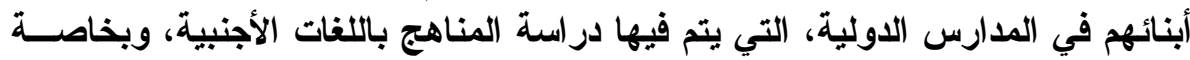

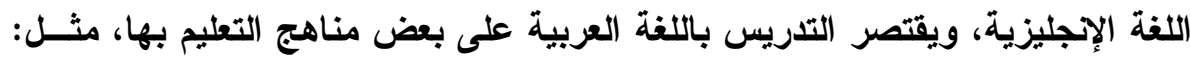
مناهج اللفة العربية، مناهج التربية الإسلامية، ومناهج الاربلة استات الاجتماعية.

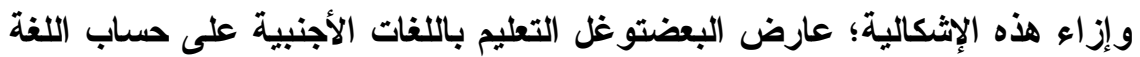

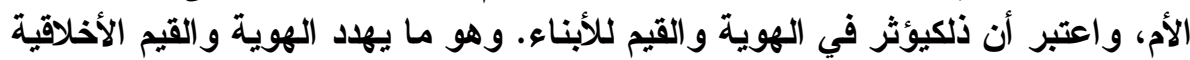

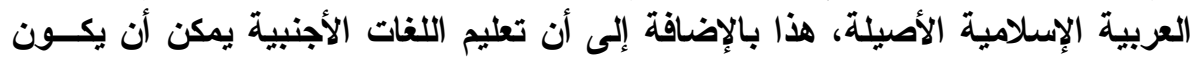
أداة لما يمكن أن يطلق عليه بالاستعمار الثقافي.

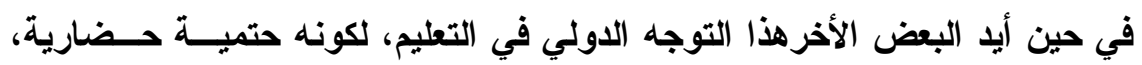

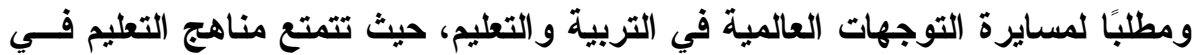

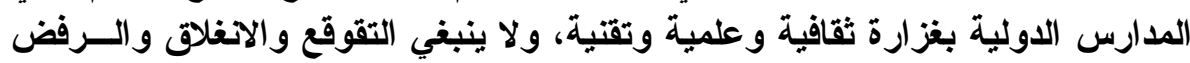

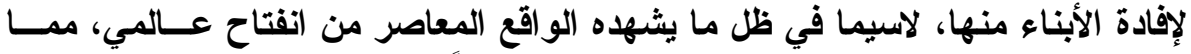

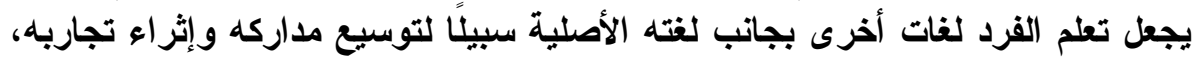

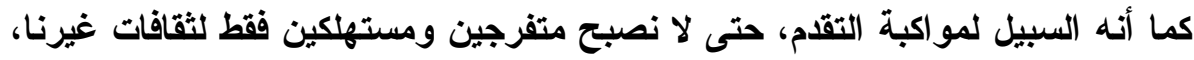

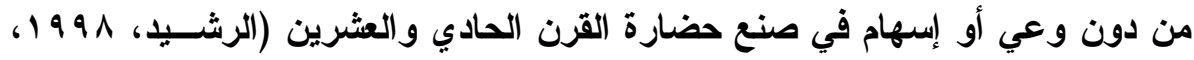

وبين كلا الاتجاهين أثثر النقاش حول عدة أمور تتعلق بوضع ومكانة التعليم باللغة

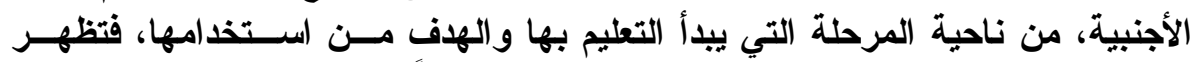

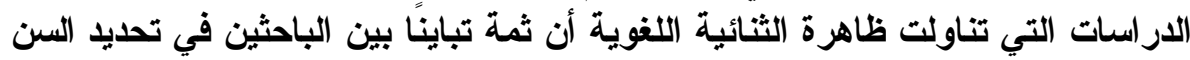

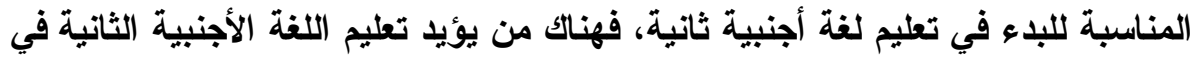

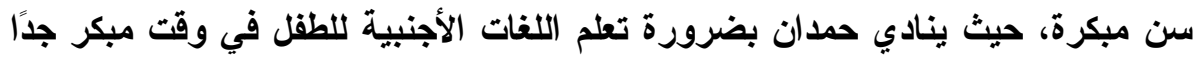

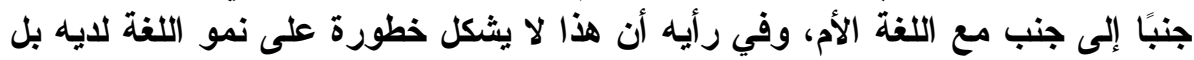

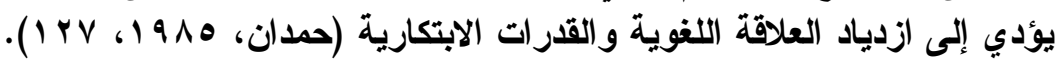

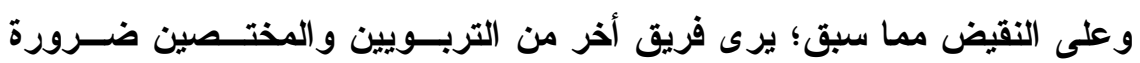

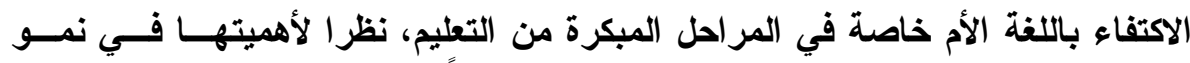

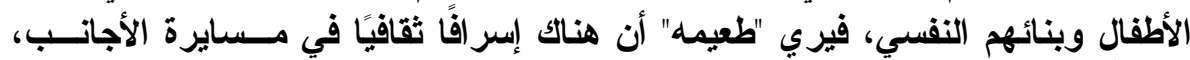

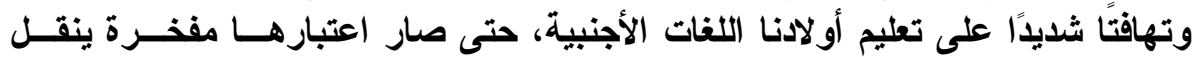

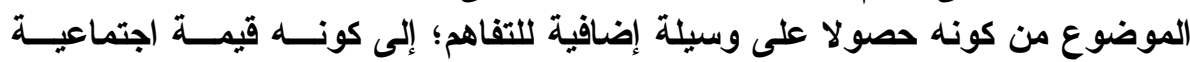


مجلة كلية التربية، جامعة الأزهر، العدد: (؛ 17 الجزء الأول) يوليو لسنة ه 1. بم

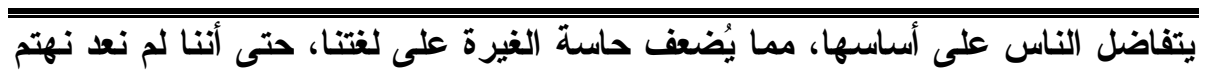

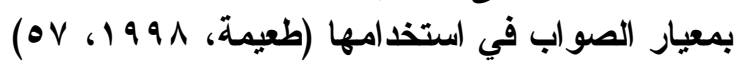

ثانيا: ماهية القيم والقيم الأخلاقية

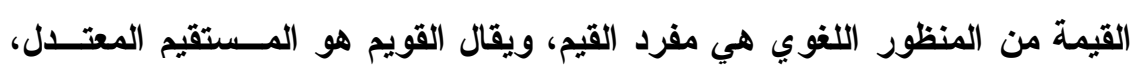

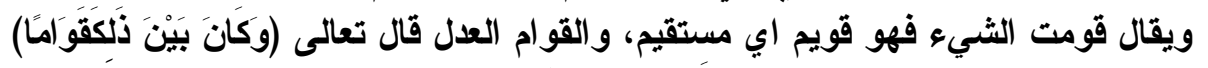

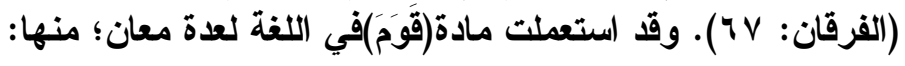

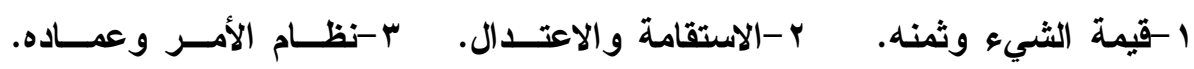
ع - الثبات و الدوام والأستمر ار.

ولعل أقرب هذه المعاتي لموضوع بحثنا هو الثبات والدوام والاستمرار على الثيء.

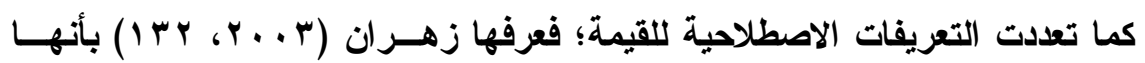

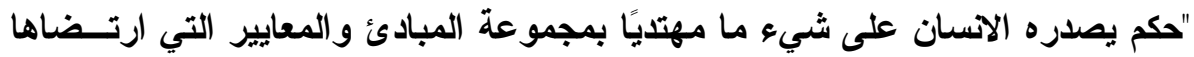

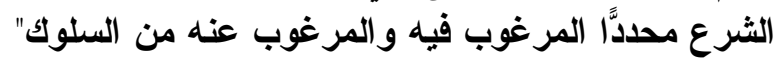

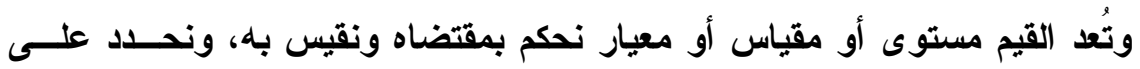

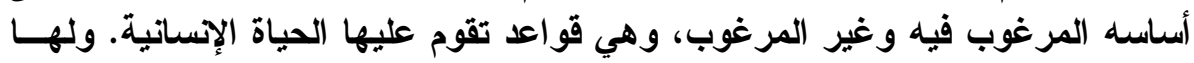

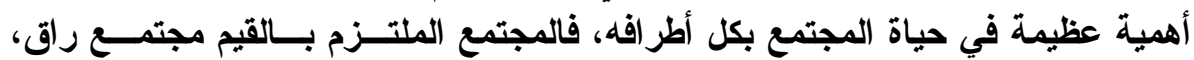

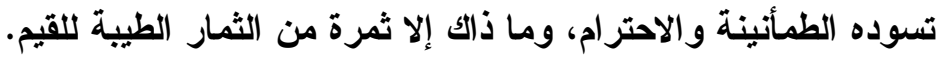

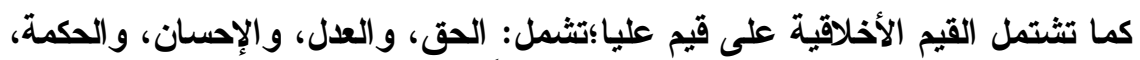

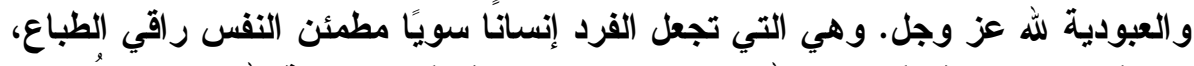

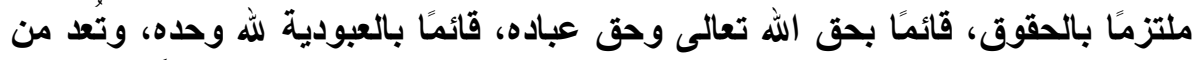

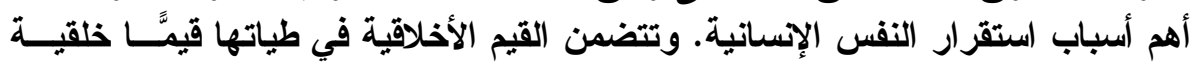

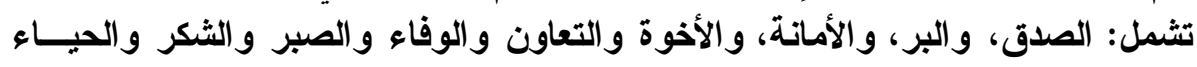

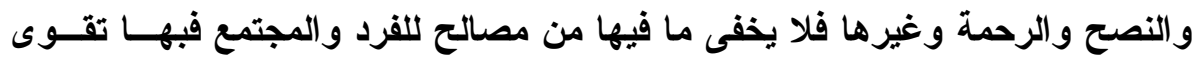

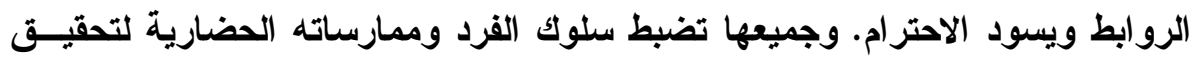

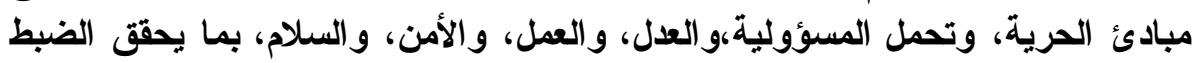

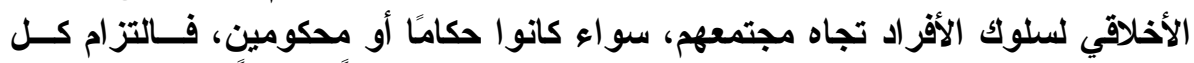

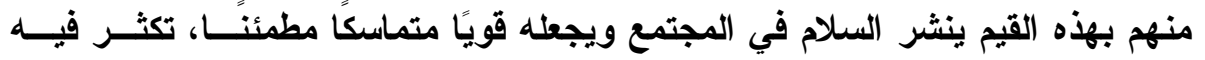
الفضيلة وتتضاعل فيه الرذيلة.

وعلى الرغم من كون القيم جزءًا من الثقافة؛ إلا أنها غالبًا ما تكون مهيمنة عليها.

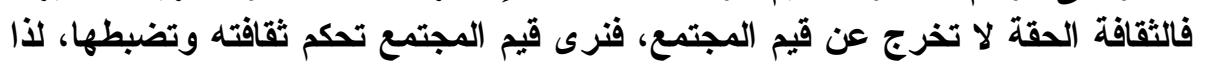

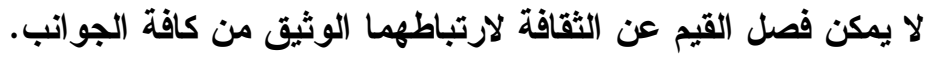


ومن أبرز الخصائص المميزة للقيم أنها عناصر توجيه في الحياة تعكس توجهً

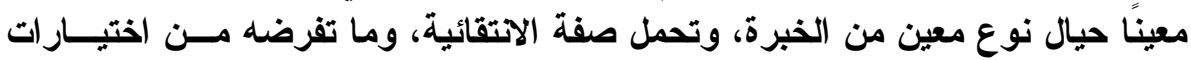
على الفرد في مجال التعامل يعد أفضل الخيارات.

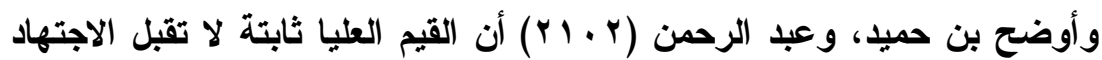

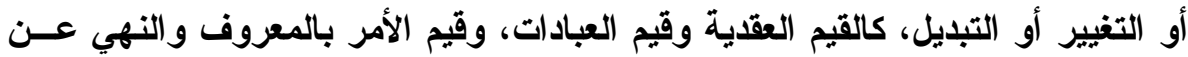

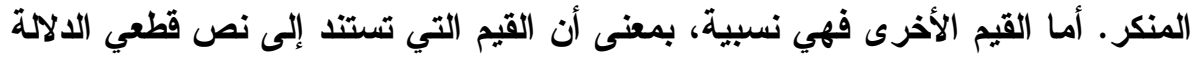

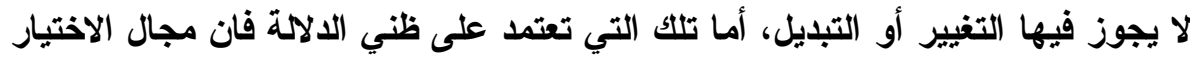

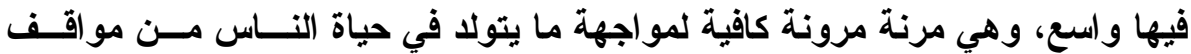

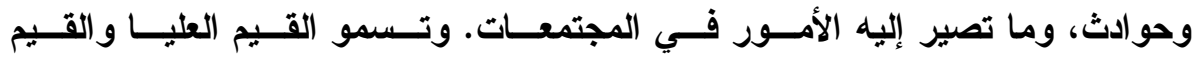

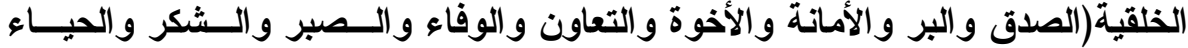

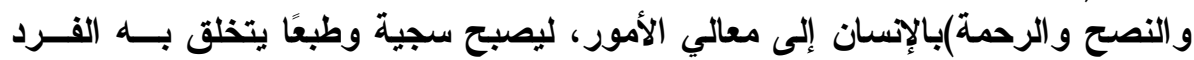

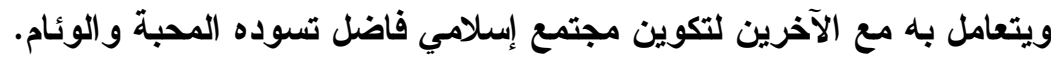

ثالثا: التدريس باللغات الأجنبية وتأثثيره في القيم الأخلاقية.

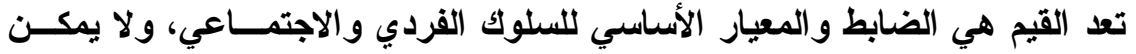

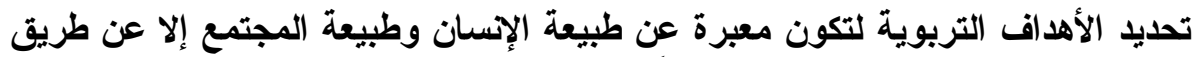

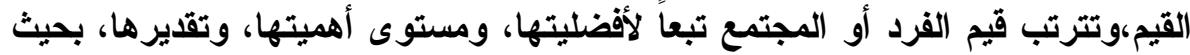
تسبق القيمة الأعظم أهمية، ثم التي تليهاءأي ترتيب هذه القيعة القيم طبقا لأولويتها.الأمر الذي

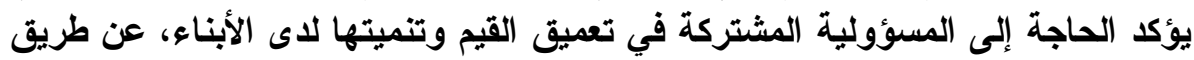
التخطيط، والتنسيق بين كافة مؤسسات المجتمع.

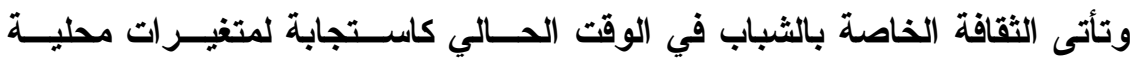

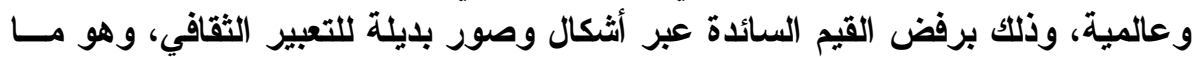

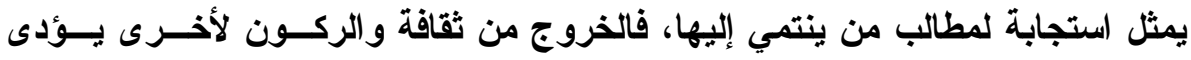

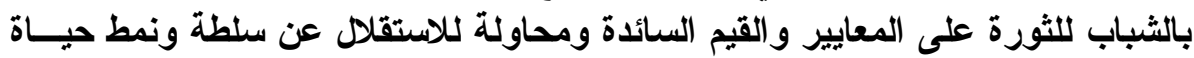

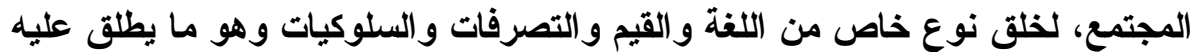

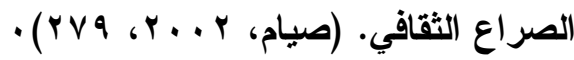

ويشهر الواقع الاجتماعي على مختلف المستويات مشكلات شبابية حادة تتخذ صوراً

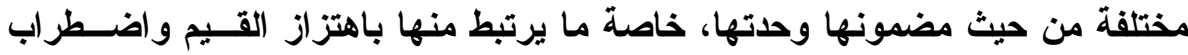

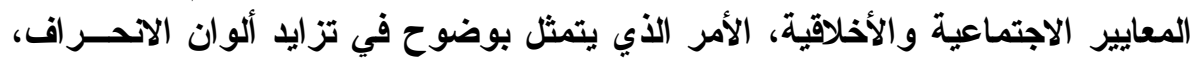

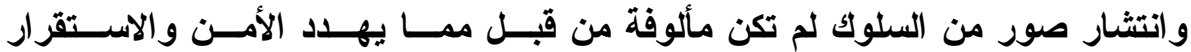

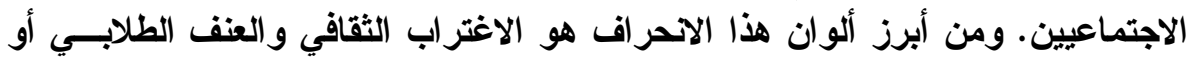

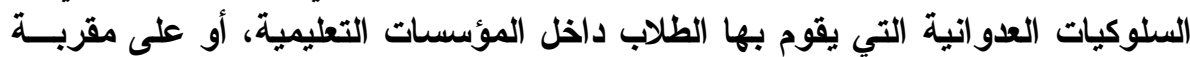


مجلة كلية التربية، جامعة الأزهر، العدد: (ع 1 الجزء الأول) يوليو لسنة ه 1 ـ بام

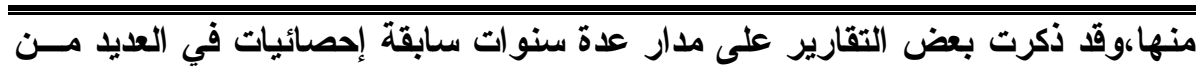

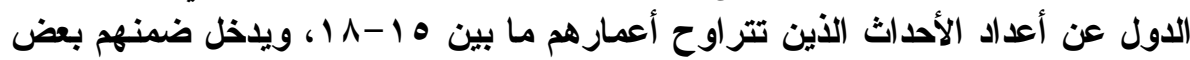

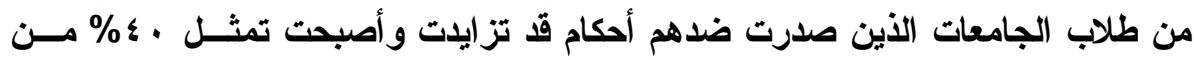

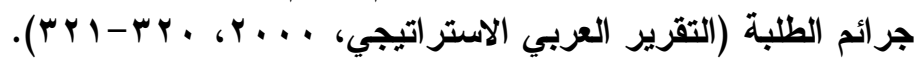

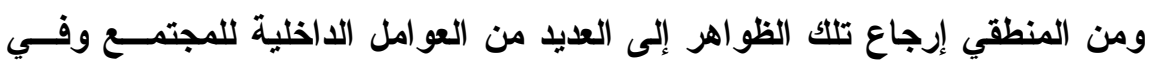

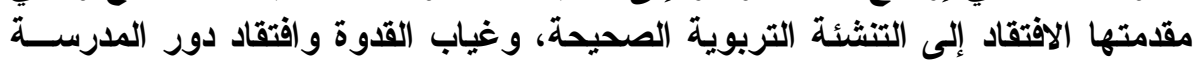

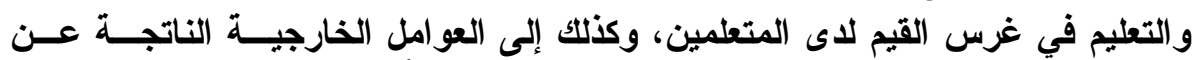

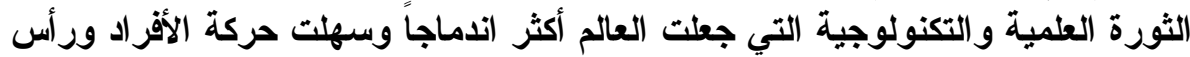

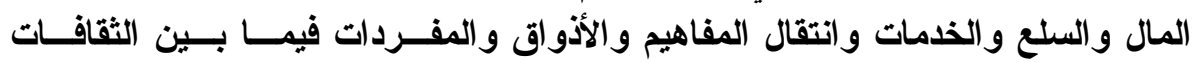

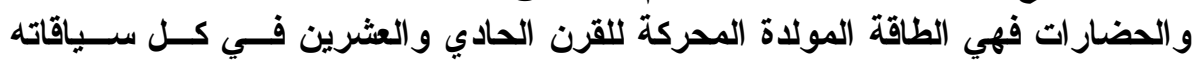

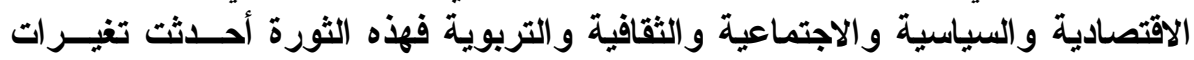

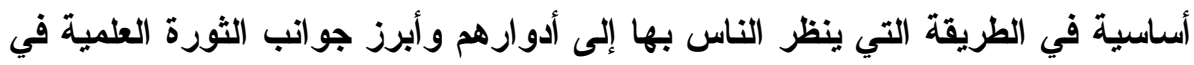

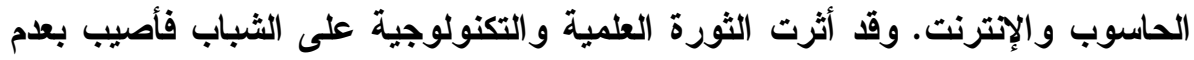

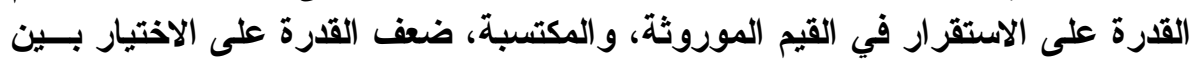

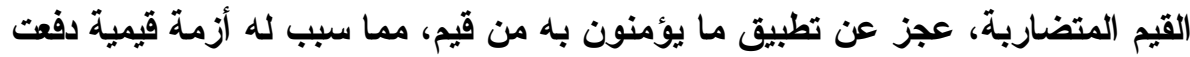

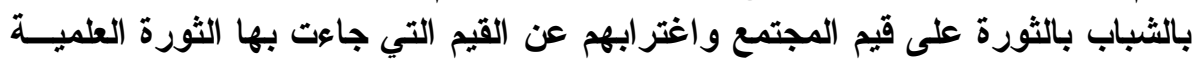

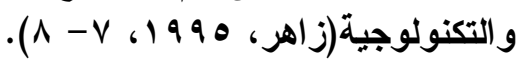

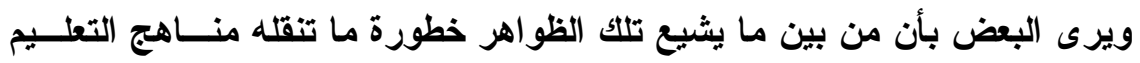

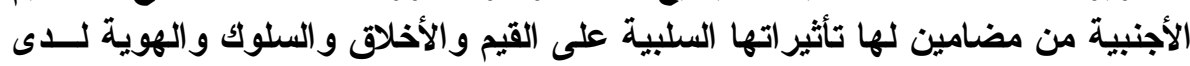

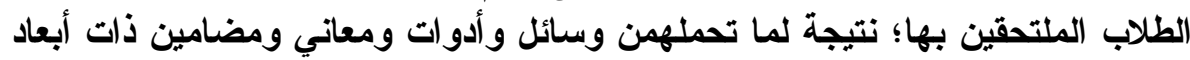

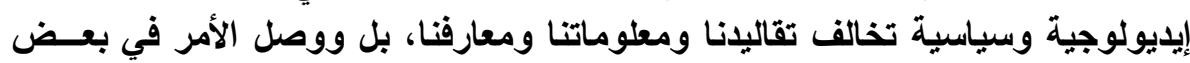

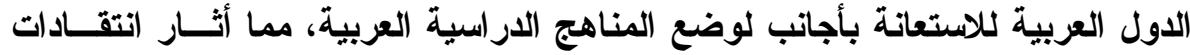

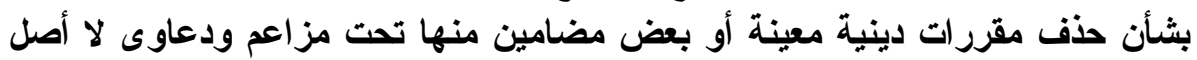

بالإضافة إلى ما فيها من تكريس وترسيخ معنى ذهني خطير في عقول الأجيال وهو

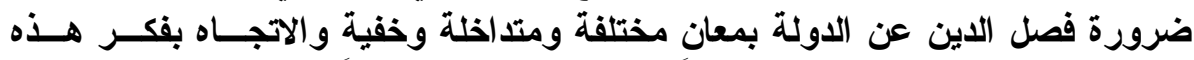

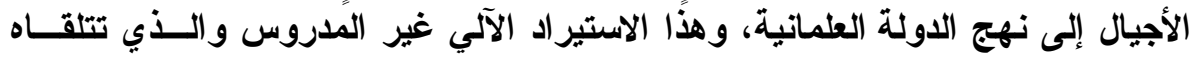

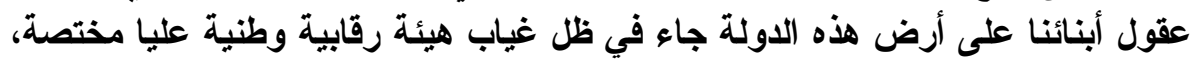

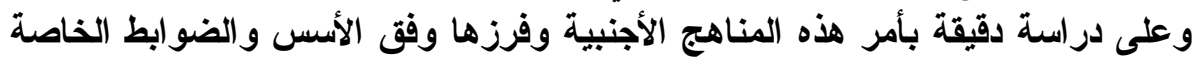

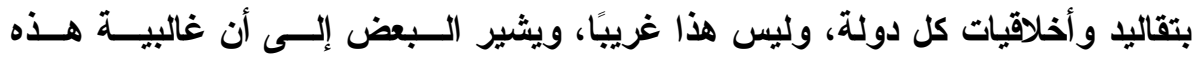

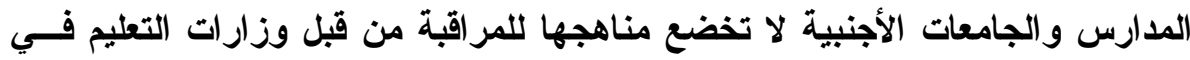
الدول العربية، وقد نتج عن ذلك حالات غريبة لتدريس كتب ومواد تخالف تاريخ من فئ وزئ وتقاليا 
وعادات المجتمعات العربية.

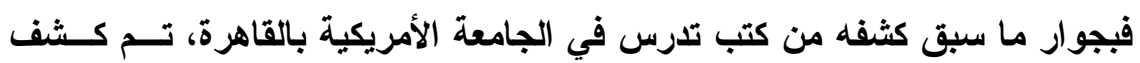

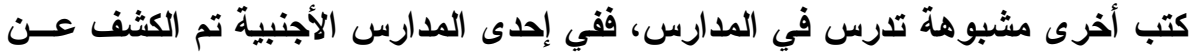

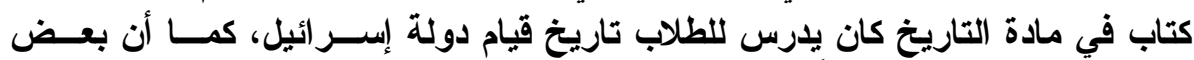

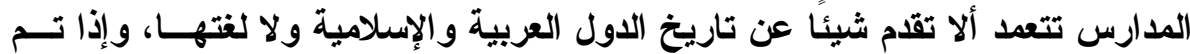
تدريسها في بعض من تلك المدارس الأجنبية فإنه يدرس من وجه الأه نظر أجنبية.

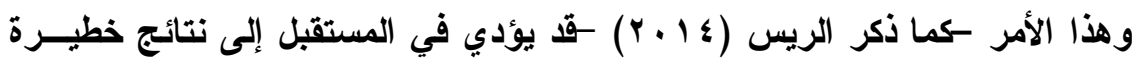

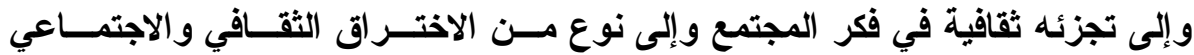

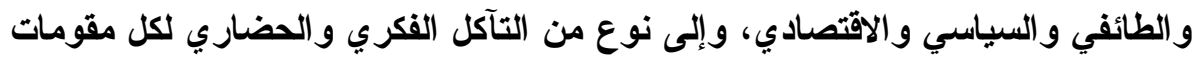

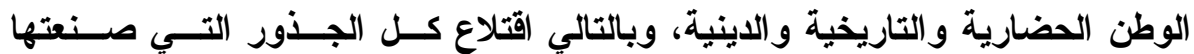
مؤسساتنا الاجتماعية والتريوية الوطنية في فكر المجتمع. (مقال: المدارس الأجنبية في بلادنا، غزو آن لله أن ينتهي).

رابعا: الدراسات التي أثارث إلى تأثثير المناهج الأجنبية على القيم الخلقية. أجرى "ثابت" دراسة عن "الهوية العربية الإســلامية ودور المؤسـسـة التعليميـة

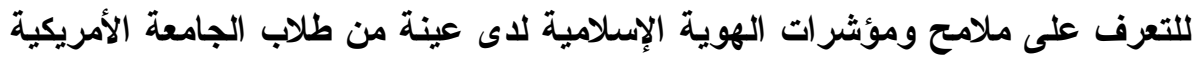
بالقاهرة، وجاءت النتائج كما يلي:

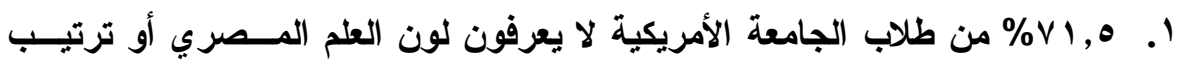
ألو انه.

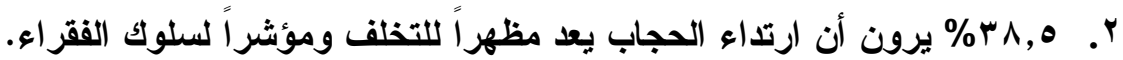

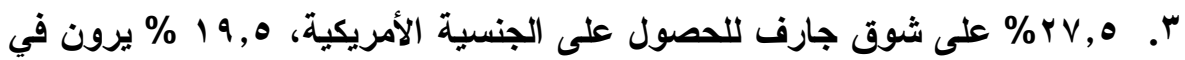

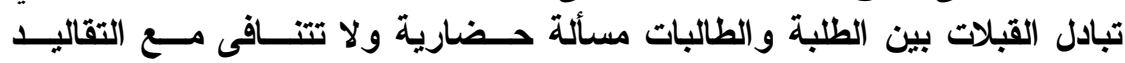
المصرية.

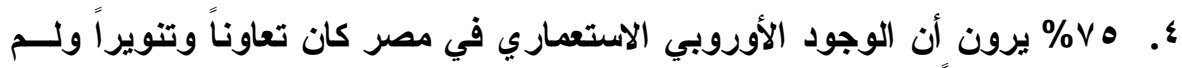

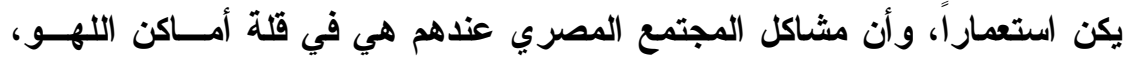

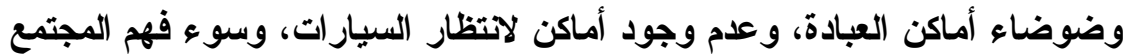

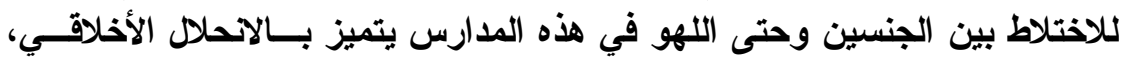

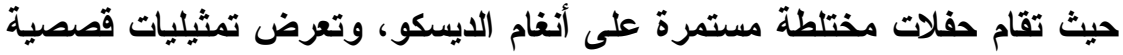

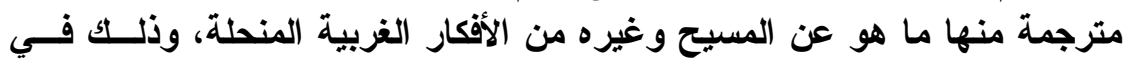

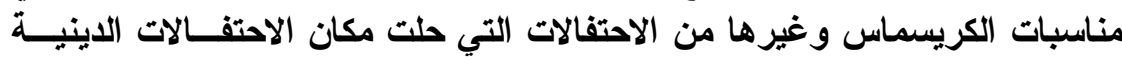
كعيد السنة الهجرية وعيد المولد النبوي. 
مجلة كلية التربية، جامعة الأزهر ، العلد: (ع 17 الجزء الأول) يوليو لسنة هـ 1 ـ rم

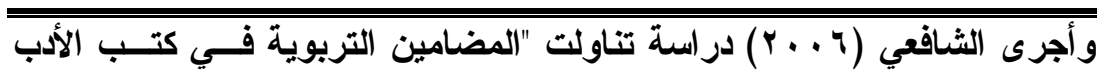

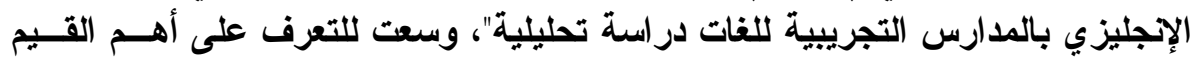

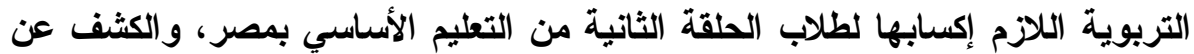

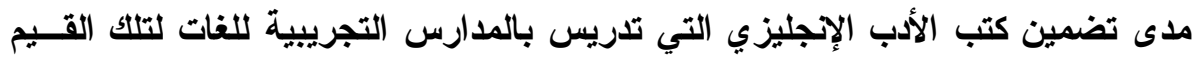

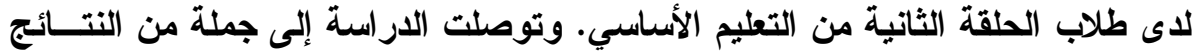

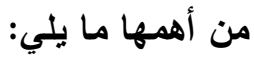

ا. أن أهداف تدريس كتب الأدب الإنجليزي بالمدارس التجريبية للغات لا تتضمن

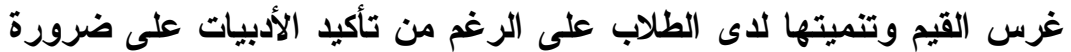
تضمين أهداف المقررات الارسية للقين الطيم التربوية.

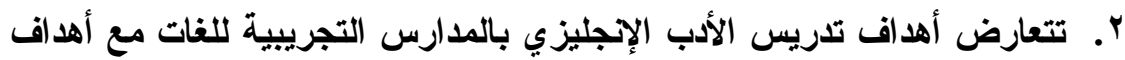

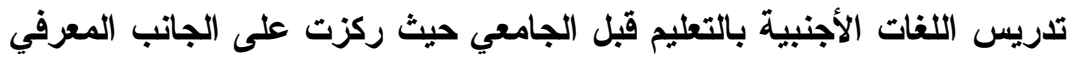

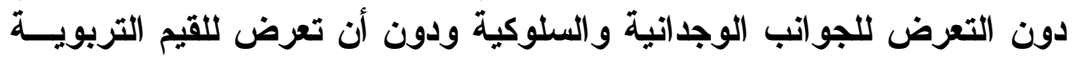
وغرسها لاى الطلاب وتربية شخصياتهم تربية شاملة.

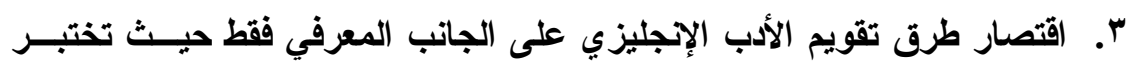
قرة الطالب على الحفظ والاستظهار.

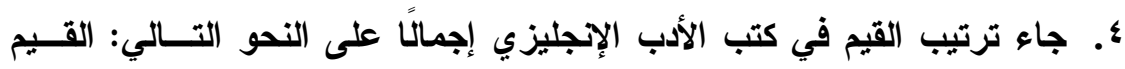
الاجتماعية - القيم الدينية - القيم الثقافية - القيب القيم السياسية.

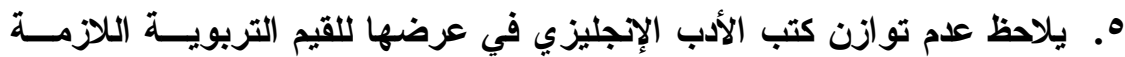
لطلاب المرحلة الإعدادية حيث أولت القيم الإينية الأيخ فئمامًا ضعيفًا.

7. تحتوي كتب الأدب الإنجليزي بالمدارس التجريبية للغات على العديد من الأماط السلوكية غير المرغوب فيها و المتعارضة مع الإبيزي القيل التربوية التي ينبغي تنميتها

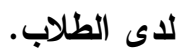
وأوصت الدراسة بضرورة إعادة النظر في أهداف تدريس كتب الأدب الإتجليزي بالمدارس التجريبية للغات بحيث تتضمن القيم التزبوية اللازمة لطلاب تلكت المرافي المرحلة.

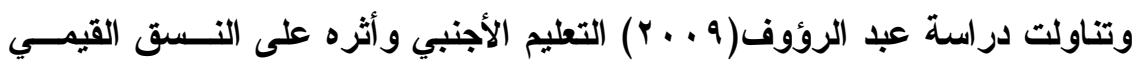
للمجتمع المصري، وأثثارت إلى أن الاختلاف بين النظام التعليمي الأمريكي والإنجليزي

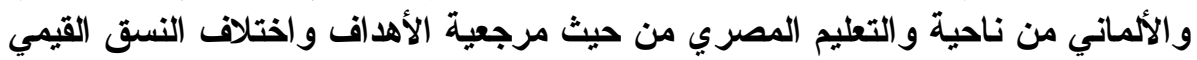

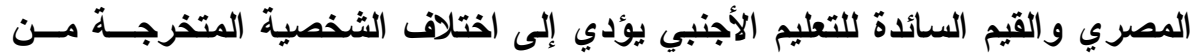

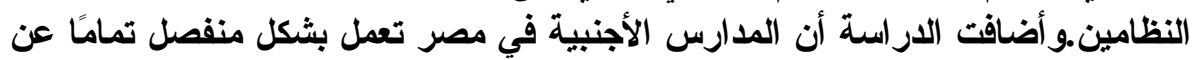
المجتمع المصري ولا تقع تحت طائلة أي قانون والإثر افت الوحيد في المرحلة الثانوية 
و هو مجرد إثراف صوري، في حين أنها تخضع لهيئات أجنبية تطبق عليها مقاييسها

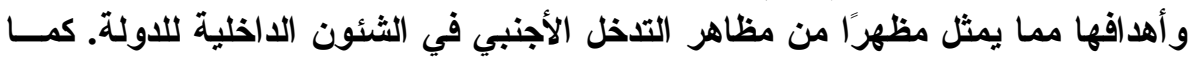

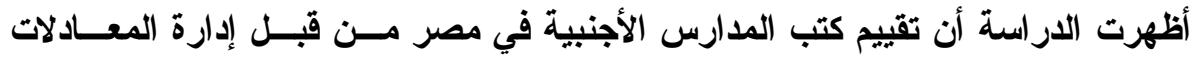

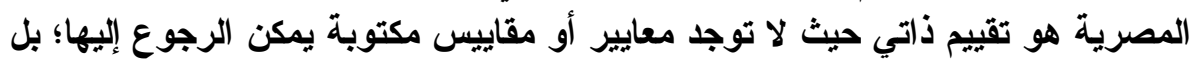

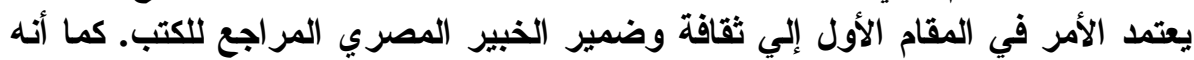

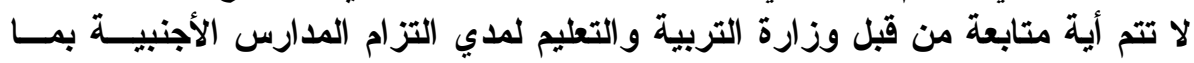

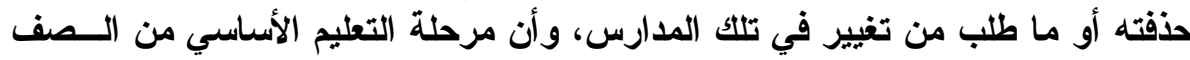

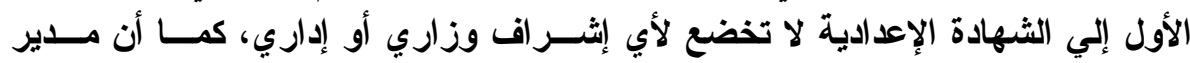

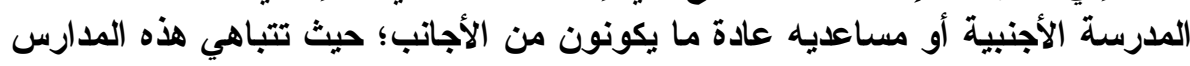

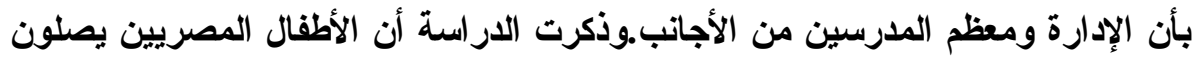

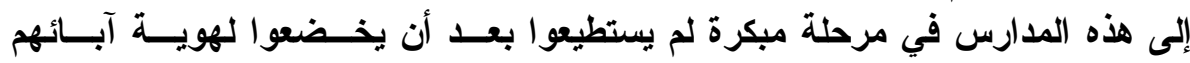

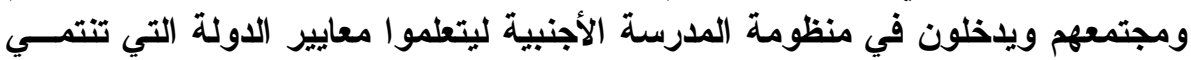

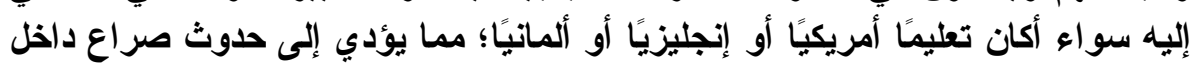

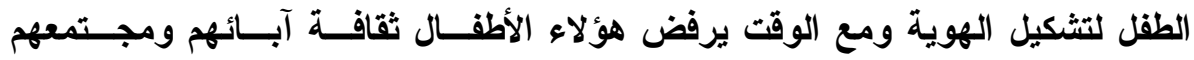

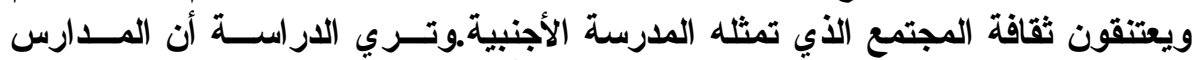

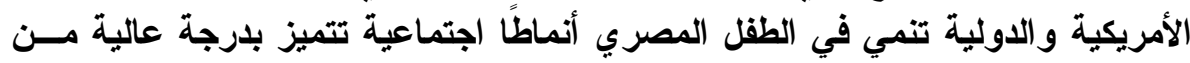

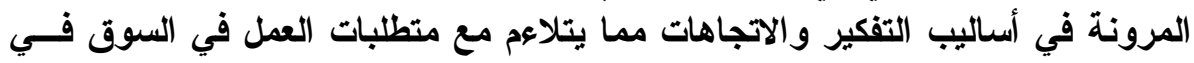

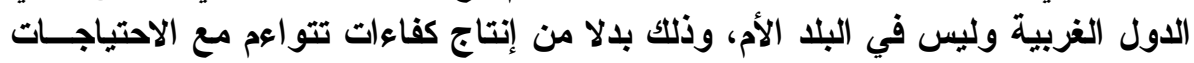

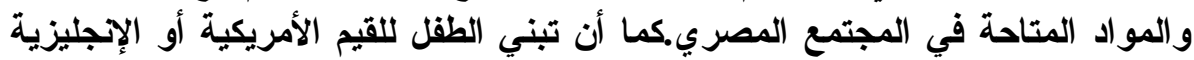

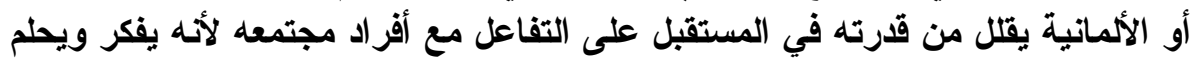

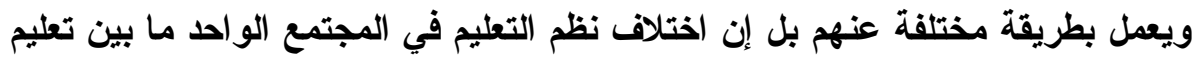

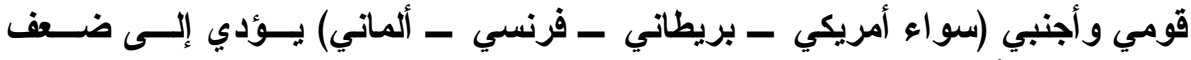

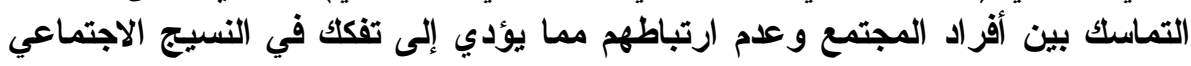

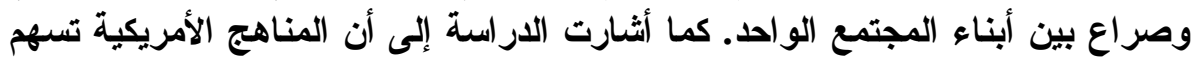

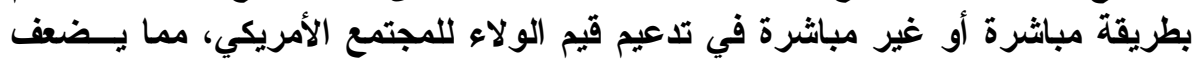

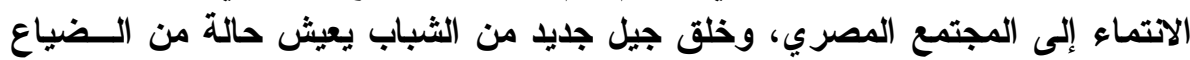

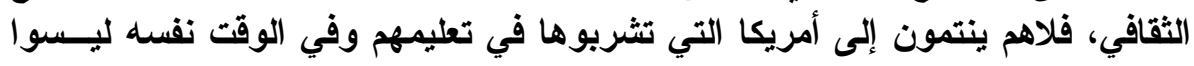

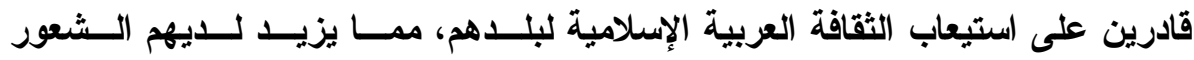

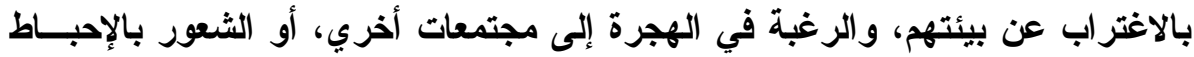

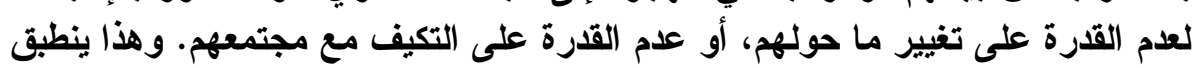

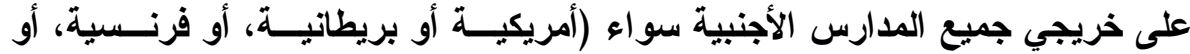




$$
\text { تعقيب على الأدبيات. }
$$

يتبين من العرض السابق للأدبيات تعدد الآثار السلبية للتعليم باللغات الأجنبية نتيجة

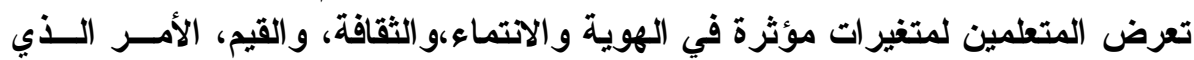

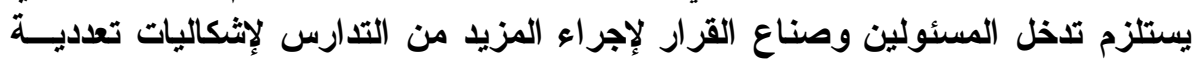

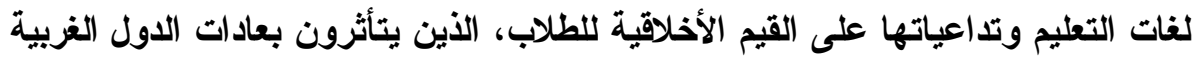

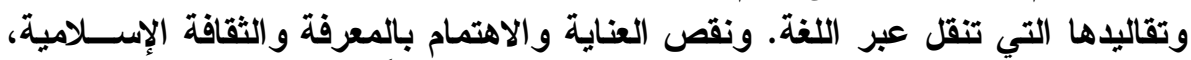

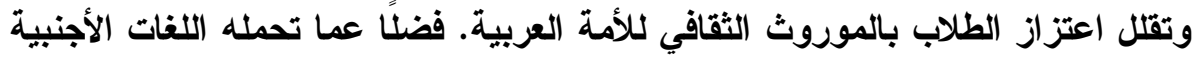

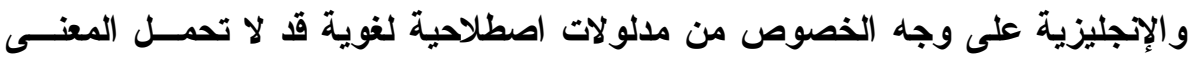

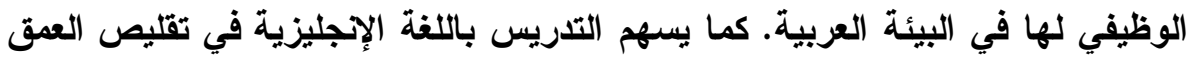

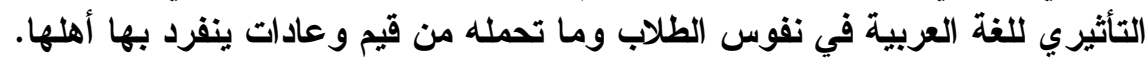

$$
\text { ثالثا: منهج البحث و إجراء) }
$$

مر البحث بالخطوات والإجراعات النظرية والميدانية التالية: أولاً: منهج البحث.

تم اتباع المنهج الوصفي التحليلي للإجابة عن أسئلة البحث. ثانيا: إجراعات إعداد أداة البحث وضبطها. مرت عملية إعداد أداة البحث وضبطها بالخطوات التالية:

(1) الستعر اض الأدبيات السابقة التي تناولت التدريس باللغات الأجنبية وأثرها في القيم

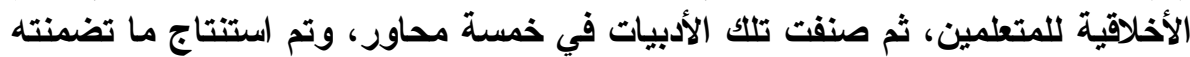

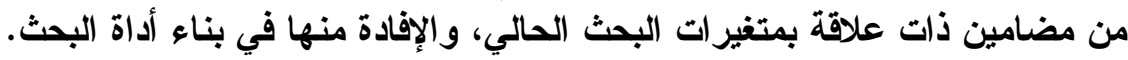

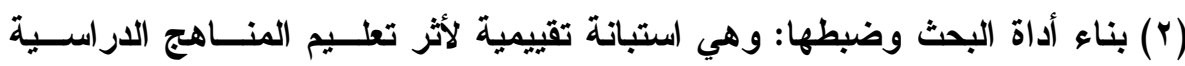

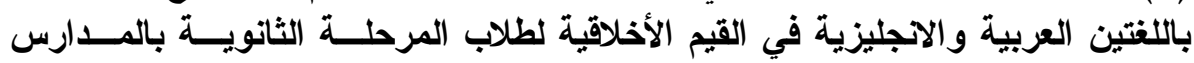

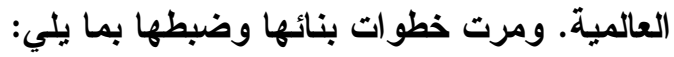

(أ) تحديد قائمة أولية شملت ثلاثة محاور معيارية للقيم الأخلاقية، يتبع كل منهــــا معايير فرعية، ومؤشرات سلوكية وذلك على النحو التالي: أولا: معايير القيم الخلقية، وتثتمل على معيارين لبعدين فرعيين، هما:

$$
\text { ا-نمو الوازع الديني الخلقي. ويتبعه (7) مؤشر ات سلوكية. }
$$

r-التحلي بالمسؤولية والالتزام الخلقي مع الــنفس والآخــرين. ويتبعـهـ (0)

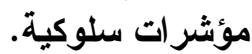


ثناتيا: معايير القيم الروحية، وتثنتمل على معيارين لبعدين فرعيين، هما:

1-ترسخ العقيدة الإيمانية بالله والأخوة في الله. ويتبعه (^) مؤثرات سلوكية.

r-إدر الك حقيقة الكون و الحياة الإسانية. ويتبعه (ع 1) مؤشرًا سلوكيًا.

ثالثا: معاير القيم السلوكية، وتثتمل ثلاثة معايير لثلاثة أبعاد فرعية، هما:

1-الاتتماء للادين و الوطن و اللغة. ويتبعه (0) مؤشرات سلوكية.

r-الالتزام بالمحددات الثقافية والفكرية. ويتبعه (r I ) مؤشرًا سلوكيًا.

r-احترام القيم والأعراف والتقاليا الاجتماعية. ويتبعه (^) مؤشرات سلوكية.

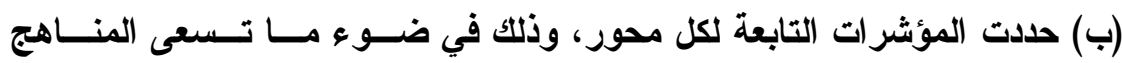
الدراسية للغة العربية والتربية الإسلامية والاجتماعيات إلى تنميته من قيم لدى لدى

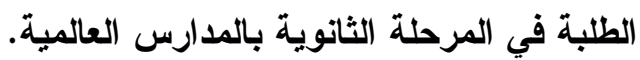

(ج) أعدت صفحة التعليمات للاستبانة، وشملت الغرض منها، وكيفية الاســتجابة عليها، و البيانات الخاصة بالمستجيب.

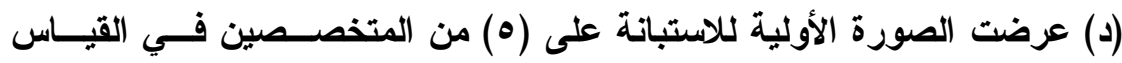

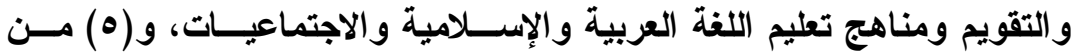

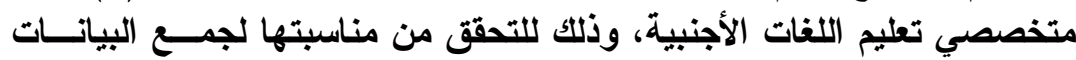
حول أثر تعليم المناهج الاراسية باللغتين العربية والإنجليزية ودئة في القيم الأخلاثية

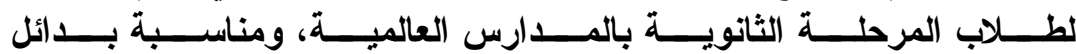
الاستجاباتوتقدير اتها، ولأهم الملاحظات التطويرية المقترحة.

(0)روعيت ملاحظات المحكمين، تم طبقت الاستبانة على عينة اســنطلاعية بـــــ

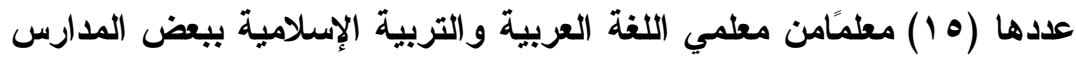

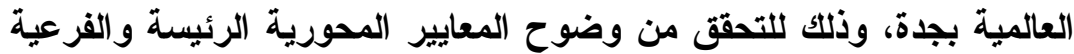
التابعة لها، والمؤشرات الدالالية السلوكية التي تقابل كل منها.

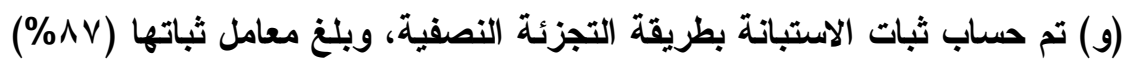
وهي نسبة مناسبة لثباتها. (shinn, 1998)

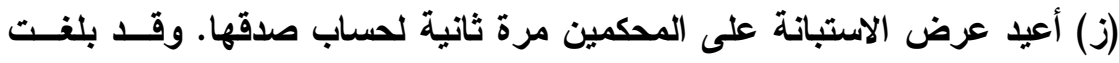

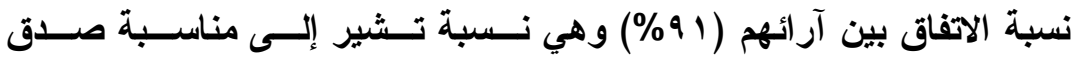
الاستباتة(shinn, 1998)، ومن ثم صلاحيتها للتطبيق على عينة البحث. وبذلك اشتملت الاستبانة في صورتها النهائية على ثثلاثة معايير قيميــة رئيسـة، 
مجلة كلية التربية، جامعة الأزهر ، العلد: (ع 17 الجزء الأول) يوليو لسنة 1 ا بام

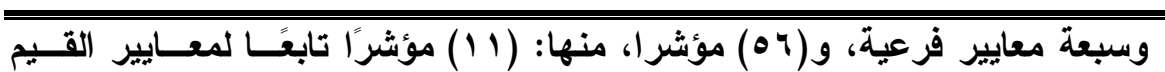

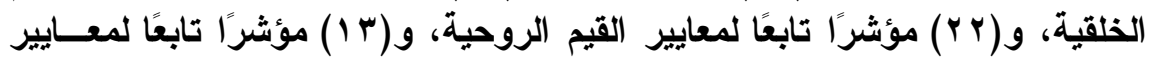

$$
\text { القيم السلوكية. (ملحق البحث) مؤثراً تابعًا }
$$

ثالثا: إجراعات التطبيق الميداني لأداة البحث.

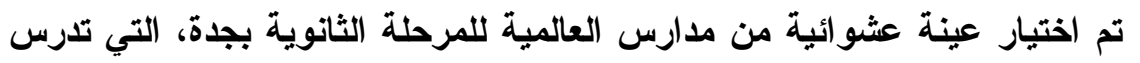

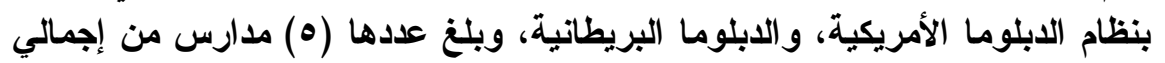

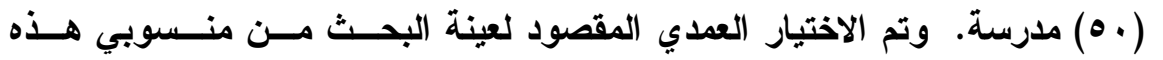

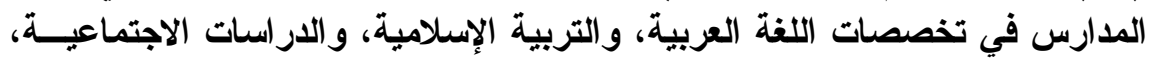

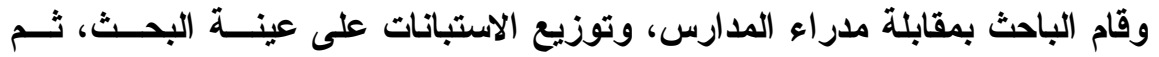

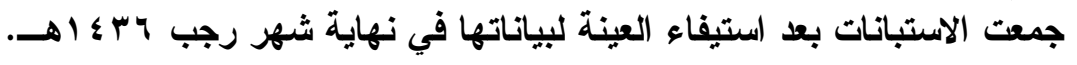

ويمكن توضيح وظائفهم، وتخصصاتهم، وأعداد أفر اد العينة في الجدول (1) الجدول (1) وظائف الأفر اد عينة البحث وتخصصاتهم وأعدادهم

\begin{tabular}{|c|c|c|c|c|c|c|}
\hline المجموع & ملير & وكيل & مرشد & مشرف & معلم & الوظائف \\
\hline 11 & $r$ & 1 & - & 1 & $1 \leqslant$ & لغة عربية \\
\hline IV & - & 1 & - & $r$ & $1 \varepsilon$ & تربية إسلامية \\
\hline 14 & $r$ & 1 & 1 & $r$ & 7 & اجتماعية \\
\hline$\leqslant \wedge$ & 0 & $\mu$ & 1 & 0 & ץ & المجموع \\
\hline$\% 1 \ldots$ & $1 \cdot 68$ & $9, Y$ & $r, 1$ & $1 \cdot, \varepsilon$ & $v \cdot, \Lambda$ & $\%$ \\
\hline
\end{tabular}

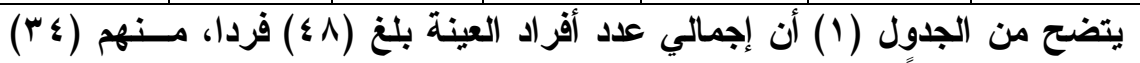

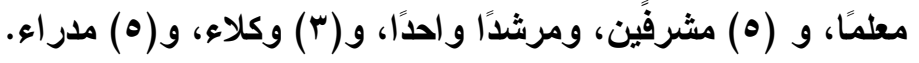
رابعاً: إجر اعات رصد النتائج ومعالجتها إحصائيًا. مرت عملية رصد النتائج وجدولتها تمهيدًا للإجابة عن أسئلة البحث؛ بـالخطوات

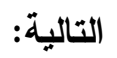
ا-رصدت تكرارات استجابات العينة، ثم قدرت درجات الاستجابات بواقع (ه) درجات

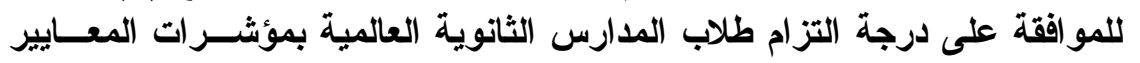




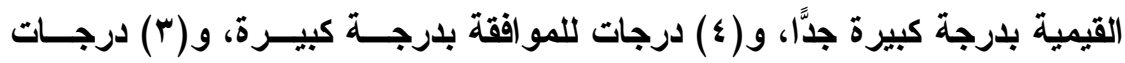

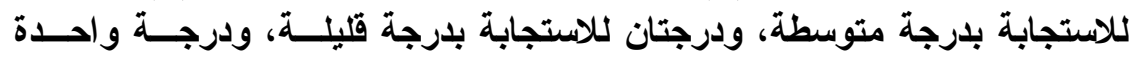
للاستجابة بدرجة بدرجة قليلة.

r-حسبت المتوسطات النسبية المئوية للاستجابات الخاصة بكل مفردة،وكذلك المتوسط بله الكلى، المحصلة لكل محور، ومحصلة الاستبانة ككل.

r-رتبت مفردات كل محور ترتيبًا تنازليًا وفق المتوسط النسبي لمحصلة الاســتجابات

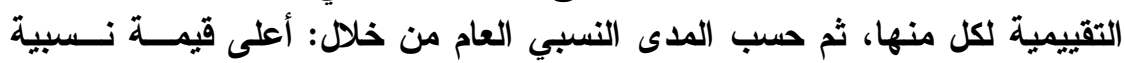

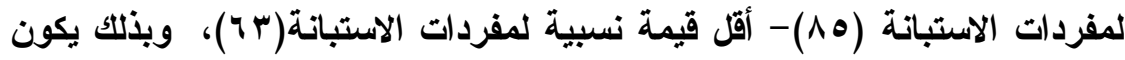
مدى التباين= r r r.

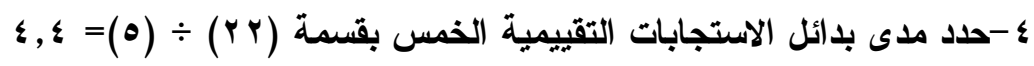

$$
\begin{aligned}
& \text { ويذلك يكون المدى التقييمي للاستجابات كما هو مبين في الجدول (r): }
\end{aligned}
$$

الجدول (r)

\begin{tabular}{|c|c|c|}
\hline المدى التقييمي النسبي & مسترمى مستوى التقييم وفقا لتوفر القـيم ومؤثـــر اتها & b \\
\hline $7 V, \varepsilon-7 T$ & بلرجة قليلة جدا (ق ج) & 1 \\
\hline$V 1, q-7 v, 0$ & بدرجة قليلة (ق) & $r$ \\
\hline$V Y, \varepsilon-V Y$ & بلدرجة متوسطة (م) & $r$ \\
\hline$\Lambda \cdot, q-v^{\prime}, 0$ & بلرجة كبيزة (ك) & $\varepsilon$ \\
\hline$\Lambda \theta-\Lambda 1$ & بلرجة كبيزة جدا (ك ج) & 0 \\
\hline
\end{tabular}


مجلة كلية التربية، جامعة الأزهر، العدد: (ع 17 الجزء الأول) يوليو لسنة 1 ــrم

$$
\text { رابعا: نتائج البحث }
$$

تمت جدولة نتائج استجابات العينة على الاستبانة، تمهيدا للإجابة عن أسئلة البحث

$$
\text { على النحو التالي: }
$$

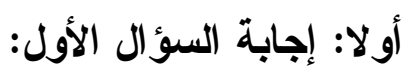

الخاص بـ: ما آراء المعلمين والمشرفين التزبويين والمدراء حول أثــر التعلـيم

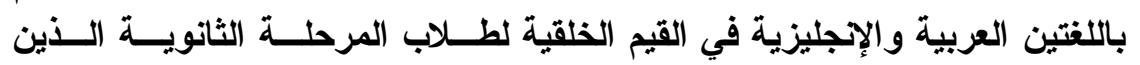

$$
\text { يدرسون في المدارس العالمية؛ }
$$

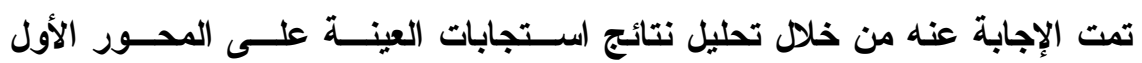
للاستبانة، الخاص بمعايير القيم الخلقية لاى طلاب المرحلة الثانوية بالمدارس العابل العالمية،

حيث رصدت النتائج في الجدول (ب):

جدول (r)

\begin{tabular}{|c|c|c|c|c|c|c|c|}
\hline \multirow{2}{*}{ 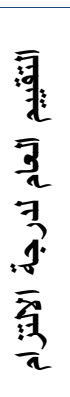 } & \multirow[b]{2}{*}{ 勇 } & \multicolumn{3}{|c|}{$\begin{array}{l}\text { النسبية\% } \\
\text { الأهمبة }\end{array}$} & \multicolumn{3}{|c|}{ المعايير القيمية الخلقية ومؤشراتها } \\
\hline & & 雪: & 里 & 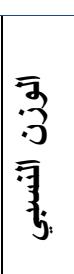 & المؤشرات & P & الخلقية القيم \\
\hline \multirow{4}{*}{$\begin{array}{l}3 \\
3 \\
3 \\
2 \\
2 \\
1 \\
\vdots \\
2 \\
2\end{array}$} & \multirow{4}{*}{ vi } & 7 & ق & 79 & 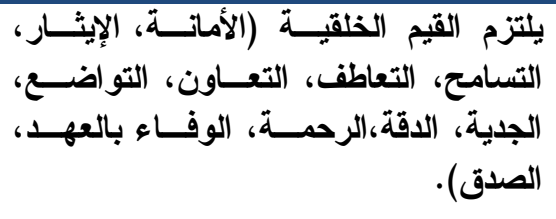 & & \multirow{4}{*}{ الخلقو الوازعي } \\
\hline & & $r$ & P & $V \varepsilon$ & 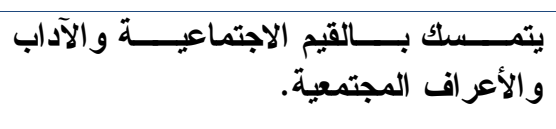 & r & \\
\hline & & 1 & S & $\mathrm{vi}$ & يظهر الو لاء والاتماء للاين و الوطن. & $r$ & \\
\hline & & $r$ & p & $V r$ & ويطبق ذلك في أقو الله و وأفعالكه السر والعلن، & ⿷ & \\
\hline
\end{tabular}

نتائج الاستجابات على محور القيم الخلقية لاى طلاب المرحلة الثانوية بالمدارس العالمية 
مجلة كلية التربية، جامعة الأزهر، العدد: (ع 1 الجزء الأول) يوليو لسنة ه 1 ـ بم

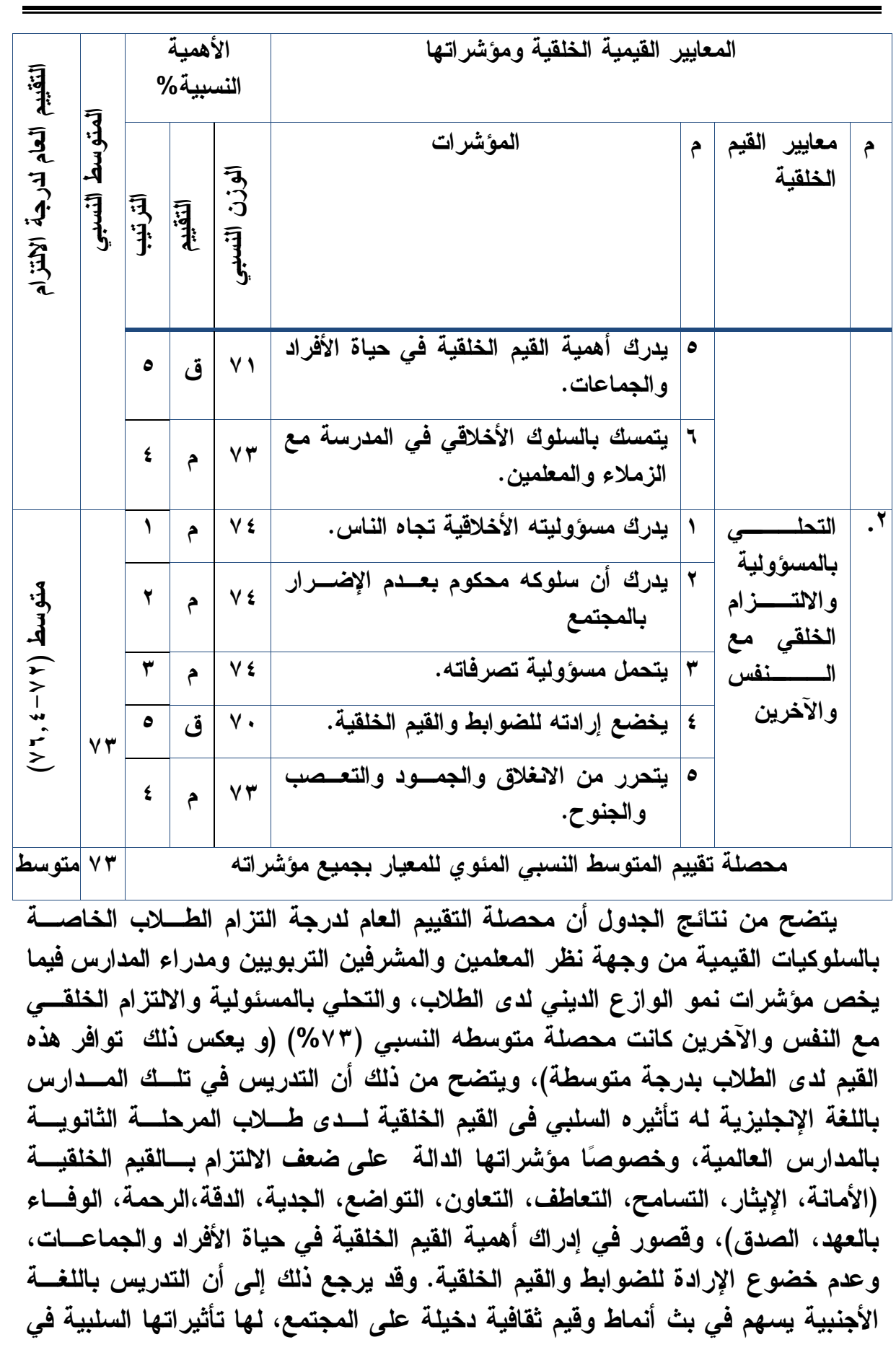

$-\varepsilon \leqslant \wedge-$ 
مجلة كلية التربية، جامعة الأزهر، العدد: (ع 1 الجزء الأول) يوليو لسنة ه 1 ـ بم

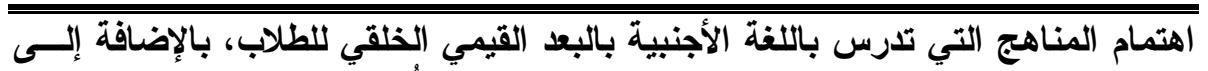

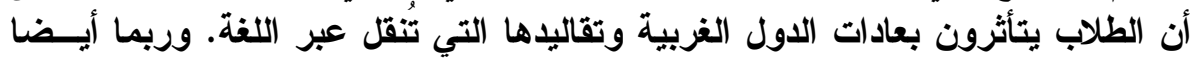

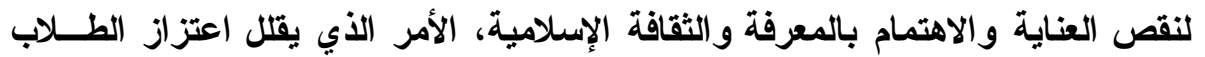
بالموروث الثقافي للأمة العربية. ثانيا: إجابة السؤال الثاني: الخاص بـ: ما آراء المعلمين والمشرفين التربويين والمدراء حول أثر التعليم باللغتين

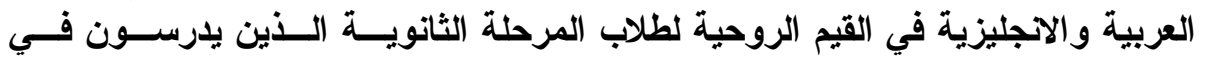
المدارس العالمية؛ تمت الإجابة عنه بتحليل نتائج استجابات العينة على المحور الثاني للاستبانة، ورصدت

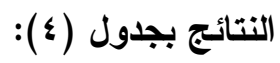

\section{جدول (๕)}

نتائج الاستجابات على محور معايير القيم الروحية

لدى طلاب المرحلة الثانوية بالمدارس العالمية

\begin{tabular}{|c|c|c|c|c|c|c|c|c|}
\hline \multirow[b]{2}{*}{ 翟年 } & \multirow[b]{2}{*}{$\begin{array}{l}\overline{7} \\
3 \\
3 \\
\overline{3} \\
\overline{3} \\
3\end{array}$} & \multicolumn{3}{|c|}{ الأهمية } & \multicolumn{4}{|l|}{ المعايير القيمية الروجية ومؤشر اتها } \\
\hline & & 浑: & 氞 & $\begin{array}{l}\overline{3} \\
: 3 \\
\overline{7} \\
3\end{array}$ & المؤشر ات & p & القــــــــــيم & b \\
\hline \multirow{8}{*}{ 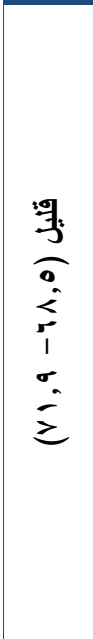 } & \multirow{8}{*}{$V_{1}, \varepsilon$} & 1 & ك & $\wedge$. & يتفهم حاجة الفرد إلى التدين الصحيح. & 1 & \multirow{8}{*}{ 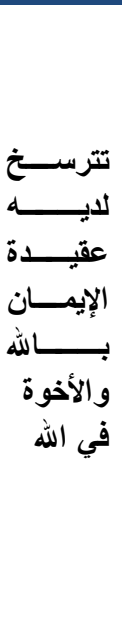 } & \multirow[t]{8}{*}{.$r$} \\
\hline & & $r$ & م & $V Y$ & يتقبل الأخر بلا تعصب أو انبهار أو ذوبان. & r & & \\
\hline & & $\varepsilon$ & ق & $v_{1}$ & يارك أهمية الحفاظ على صلته بالله تعالى. & $r$ & & \\
\hline & & r & م & $v r$ & يراعي الله تعالى في أقواله و أفعاله. & $\varepsilon$ & & \\
\hline & & 7 & ق & 79 & 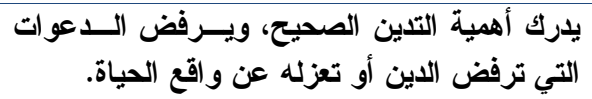 & 0 & & \\
\hline & & $v$ & ق & 79 & يحترم العقائد و الثقافات الأخرى. & 7 & & \\
\hline & & 0 & ق & V. & منه، وبمحبة صلته بالله تعالى بمحبته ورجائسـه وخـشيته & 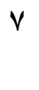 & & \\
\hline & & $\wedge$ & 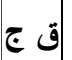 & $7 V$ & 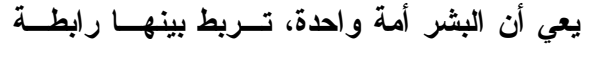 & $\wedge$ & & \\
\hline
\end{tabular}

$$
-\varepsilon \leqslant 9-
$$


مجلة كلية التربية، جامعة الأزهر، العدد: (ع 1 الجزء الأول) يوليو لسنة ه 1 ـ بم

\begin{tabular}{|c|c|c|c|c|c|c|c|c|}
\hline \multirow{3}{*}{ 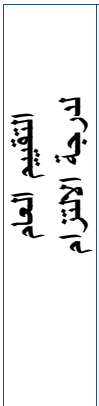 } & \multirow{3}{*}{ 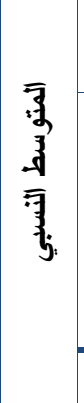 } & \multicolumn{3}{|c|}{ الأهمية } & \multicolumn{4}{|l|}{ المعايير القيمية الروجية ومؤشراتها } \\
\hline & & 牙: & 哥 & $\begin{array}{l}\overline{3} \\
3 \\
3 \\
\overline{3} \\
3\end{array}$ & المؤشر ات & b & القــــــــيمير & م \\
\hline & & & & & الإنسانية. & & \multirow{15}{*}{ 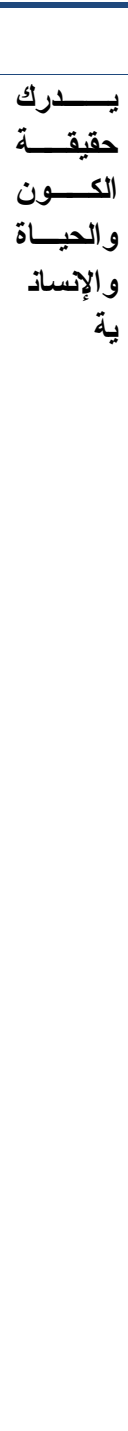 } & \\
\hline \multirow{14}{*}{$\begin{array}{l}3 \\
3 \\
3 \\
2 \\
7 \\
1 \\
\vdots \\
2 \\
2\end{array}$} & \multirow{14}{*}{$V \leqslant, r$} & 1 & ك ج & Ar & 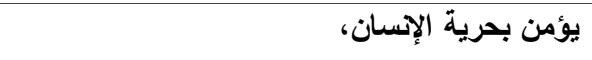 & 1 & &.$\varepsilon$ \\
\hline & & r & 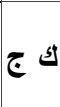 & $\wedge 1$ & الآخرين مفهوم الكرامة الإسـانية في نفـسه ومــع & r & & \\
\hline & & $r$ & ك ج & $\Lambda_{1}$ & يؤمن بان الكون مسخر لخدمة الإسسان. & $r$ & & \\
\hline & & $\varepsilon$ & ك & VV & يعي أن الحياة حادثة وصادرة عن إرادة الله تعالى. & $\varepsilon$ & & \\
\hline & & Ir & ق & 79 & يلركك أن هناك تكاملا بين الحياة الانيا والآخرة. & $\bullet$ & & \\
\hline & & 7 & p & $V \varepsilon$ & يعي أن الحياة قائمة على قاعدة الزوجية. & 9 & & \\
\hline & & 14 & 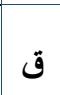 & 79 & بقالتعمير و البناء والبذل والأخاء و في العطاء و التضحية ويؤمن والحياة. & $\checkmark$ & & \\
\hline & & 11 & ق & VI & 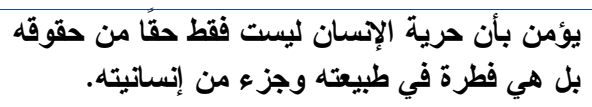 & $\wedge$ & & \\
\hline & & $1 \varepsilon$ & ق & 79 & وأنه مستخلف أن الإسـان فيه. أكرم الخلق، والكون مسخر له، & 9 & & \\
\hline & & V & r & Vr & بتظام ودقة وإنقان. & ! & & \\
\hline & & 0 & r & Vo & الكون. بارك أن مهمته في الحياة إعمار الأرض وترقيــة & 1 & & \\
\hline & & $1 \cdot$ & P & VY & 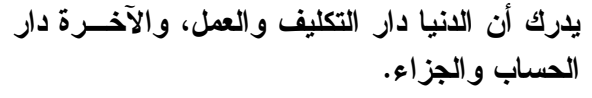 & $\begin{array}{l}1 \\
r\end{array}$ & & \\
\hline & & $\wedge$ & r & Vr & 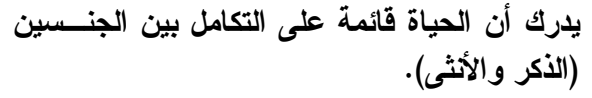 & $\begin{array}{ll}1 \\
r\end{array}$ & & \\
\hline & & 9 & r & Vr & ويتحرر من الحياة ويسعد بها ويطمئن على حياته ورزقه & $\begin{array}{l}1 \\
\varepsilon\end{array}$ & & \\
\hline \multicolumn{2}{|c|}{ V متوسط V Y, متط } & \multicolumn{7}{|c|}{ محصلة تقييم المتوسط النسبي المئوي للمعيار بجميع مؤشراته } \\
\hline
\end{tabular}




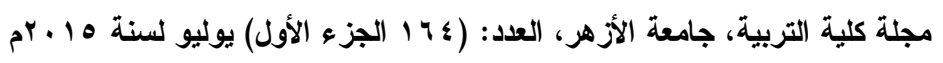

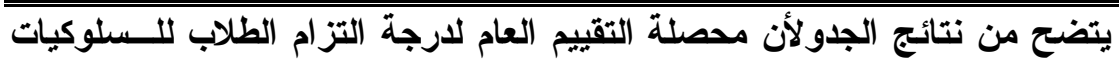

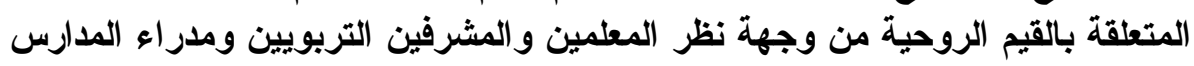

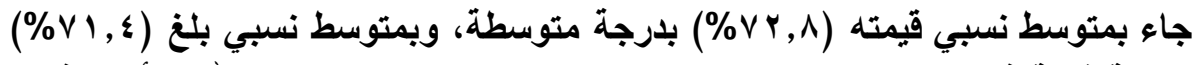

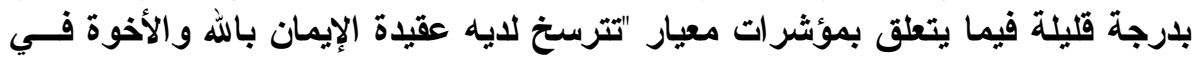

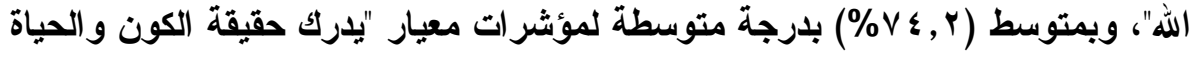

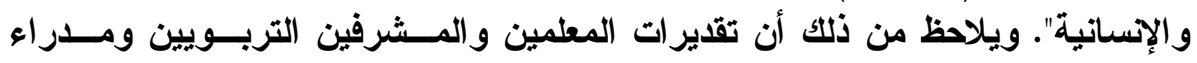

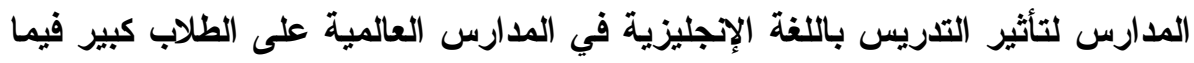

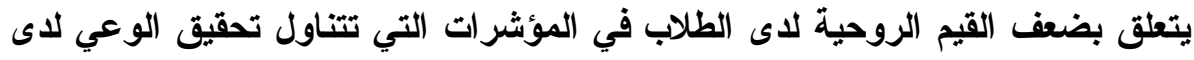

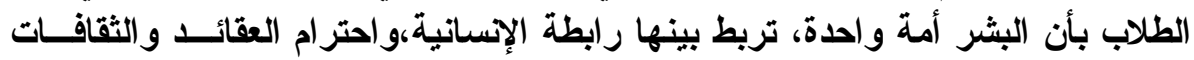

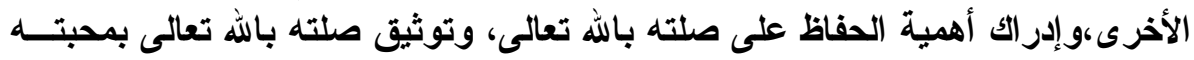

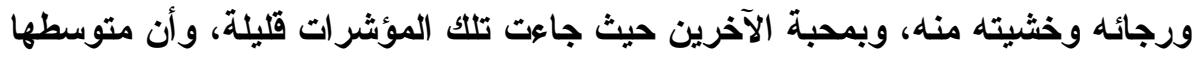

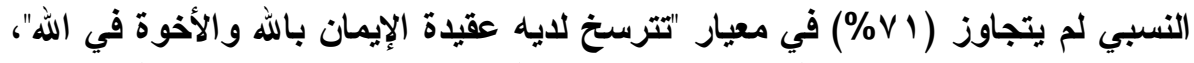

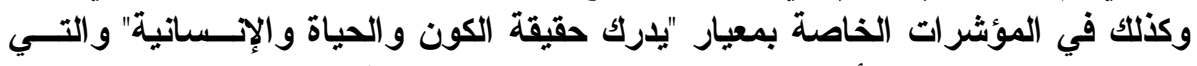

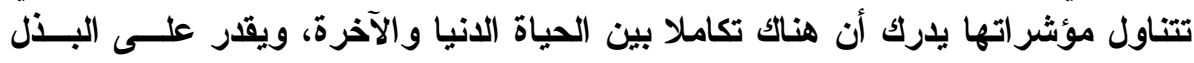

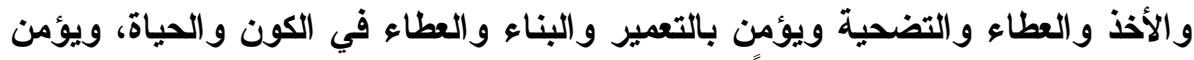

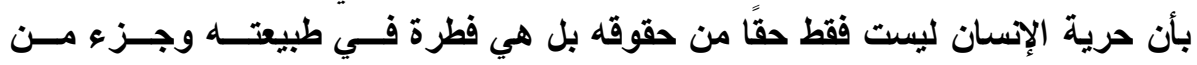

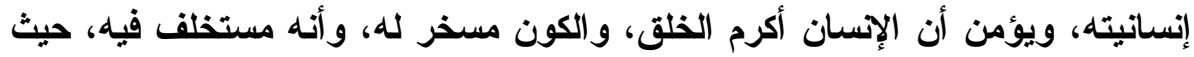

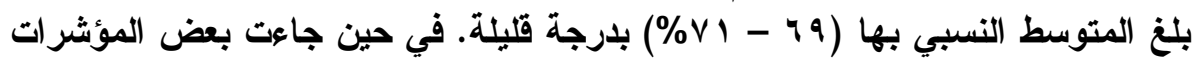

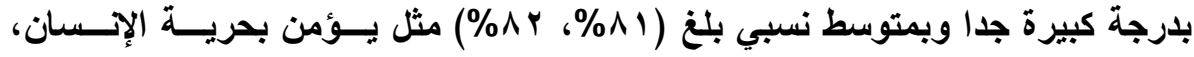

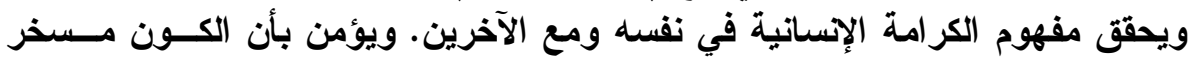
لخدمة الإنسان. 
ثالثا: إجابة السؤال الثالث.

الخاص بــ: ما آراء المعلمين والمشرفين التريويين والمدراء حـــول أثـــر التعـــــم

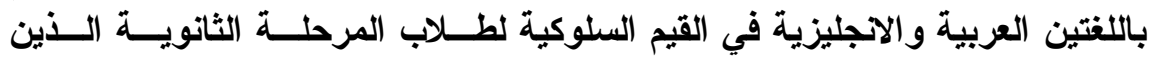

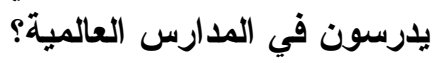
تمت الإجابة عنه بتحليل نتائج استجابات العينة على المحور الثالث للاستبانة،ورصــت

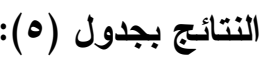
جدول (0) نتائج الاستجابات على محور معايير القيم السلوكية لدى طلاب المرحلة

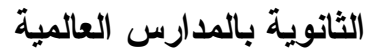

\begin{tabular}{|c|c|c|c|c|c|c|c|c|}
\hline \multirow{2}{*}{ 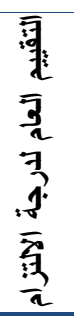 } & \multirow[b]{2}{*}{ 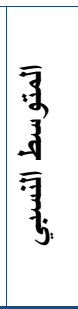 } & \multicolumn{3}{|c|}{ | الأهمية النسبية\% } & \multicolumn{4}{|l|}{ المعايير القيمية السلوكية ومؤشر اتها } \\
\hline & & 哥: & 司 & $\begin{array}{l}\overline{3} \\
.3 \\
\overline{7} \\
3\end{array}$ & المؤشرات & p & |لقــــــــــيريز & b \\
\hline \multirow{5}{*}{$\begin{array}{l}3 \\
3 \\
3 \\
2 \\
2 \\
1 \\
1 \\
\vdots \\
2 \\
2\end{array}$} & \multirow{5}{*}{$V \leqslant, \Lambda$} & r & s & $v_{4}$ & يحرص على التزامه الايني في سلوكياته. & 1 & \multirow{5}{*}{ 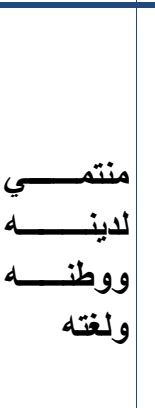 } &.$^{\circ}$ \\
\hline & & 1 & 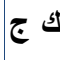 & 10 & يقر أهية الولاء لله وللوطن. & r & & \\
\hline & & $r$ & b & VI & يدرك مكانة المناسبات الاينية والاجتماعية. & $r$ & & \\
\hline & & 0 & ق ج & iv & 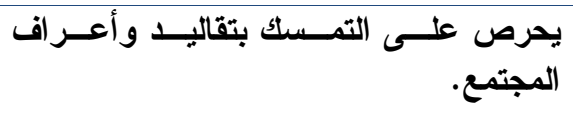 & $\varepsilon$ & & \\
\hline & & $\varepsilon$ & ق & $v \cdot$ & يقار لغته ويحرص على التواصل بها. & 0 & & \\
\hline \multirow{7}{*}{ 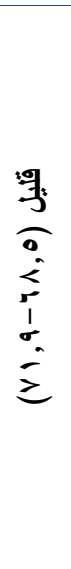 } & \multirow{7}{*}{$v_{1,1}$} & $r$ & b & $V_{4}$ & يدرك أهمية العلم وقيمته في إعمار الحياة. & 1 & \multirow{7}{*}{ | الثقافــــالقيمة } & .7 \\
\hline & & $\varepsilon$ & b & $V \leq$ & يقار قيمة العمل في ترقية القرد والمجتمع. & $r$ & & \\
\hline & & 7 & ق & $v_{1}$ & يدرك قيمة العدل في نهضة المجتمع. & $r$ & & \\
\hline & & 11 & ق & $i \wedge$ & الاحتر ام المتبادل. الآخـرين عـــى أســـس مـن & $\varepsilon$ & & \\
\hline & & Ir & 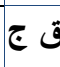 & 14 & يحرص على الاستزادة من العلم الثرعي. & 0 & & \\
\hline & & 1. & ق & 79 & يحرص على إتقان العمل. & 7 & & \\
\hline & & 1 & ك & VV & يحرص على الآتزام بالعدل وتطبيقــهـ فـــي & v & & \\
\hline
\end{tabular}


مجلة كلية التربية، جامعة الأزهر، العدد: ( 17 الجزء الأول) يوليو لسنة ه 1 ـ rم

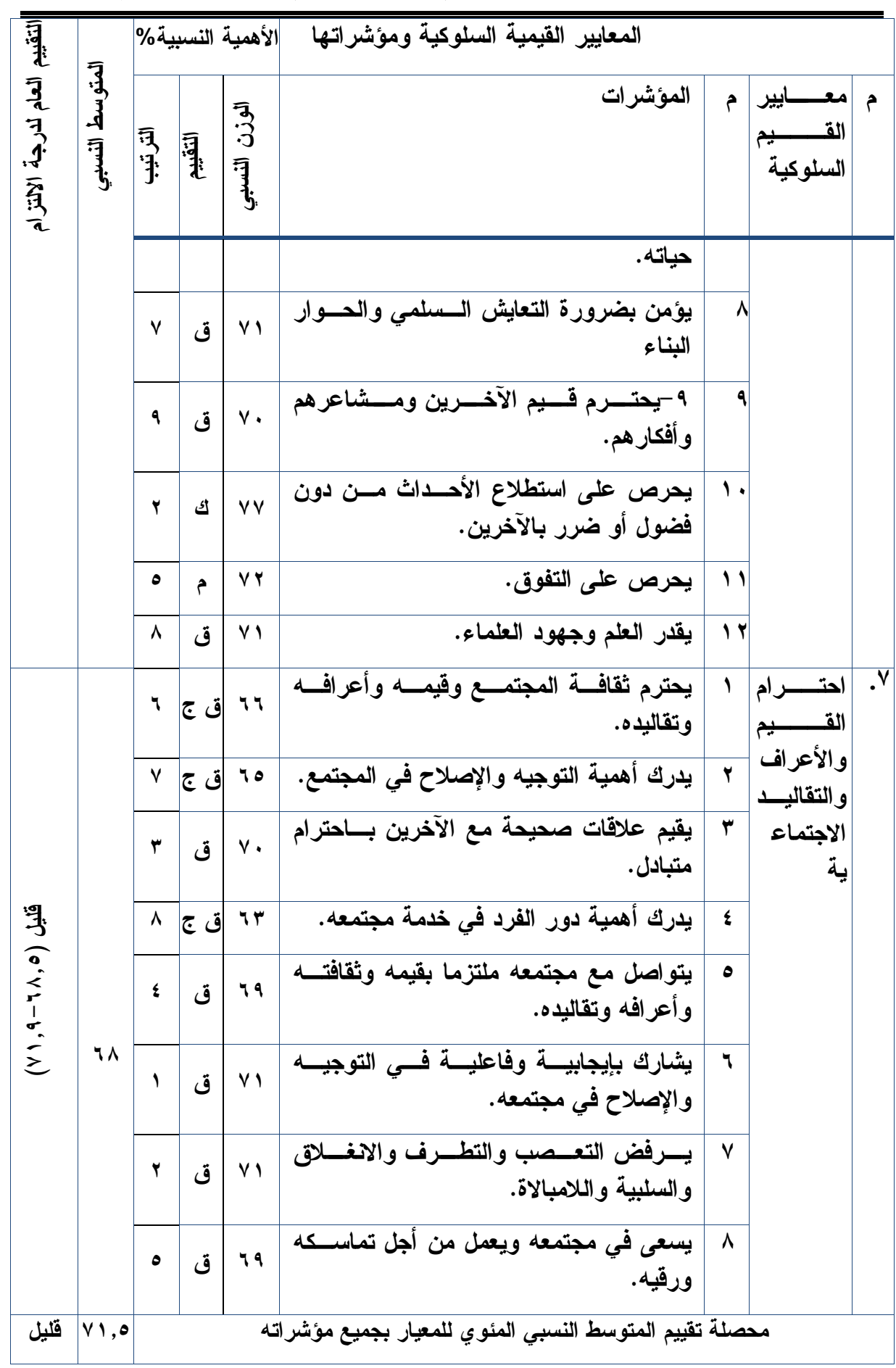

- \&OH - 
يتضح من نتائج الجدول أن محصلة التقييم العام لارجة التزام الطلاب للسلوكيات

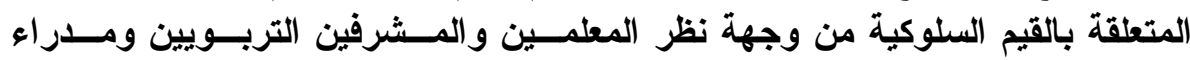

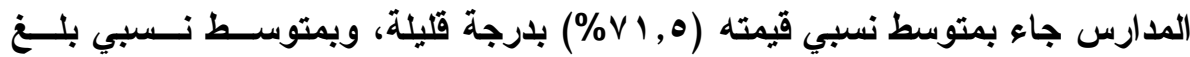
(\% ب \& , ^)

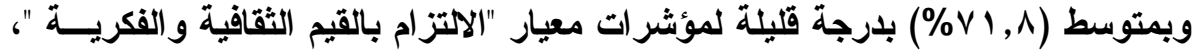

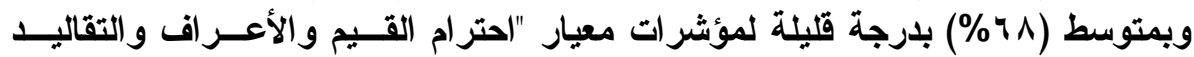

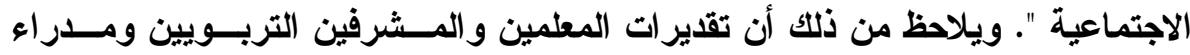

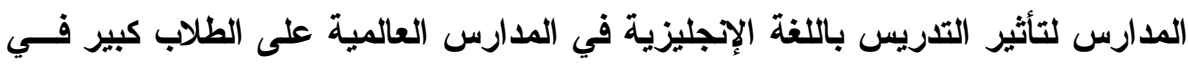
مؤشرات القيم السلوكية.

كما تم حساب المحصلة التقيمية العامة للقيم الأخلاقية بأبعادها الخلقية والروحية

و السلوكية، ورصدت النتائج في الجدول (†):

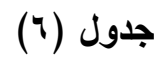

محصلة تقييم الاستجابات على استبانة تقييم القيم الأخلاقية

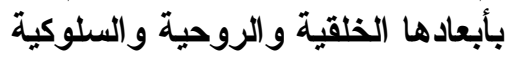

\begin{tabular}{|c|c|c|c|c|c|c|c|c|}
\hline \multirow{2}{*}{ 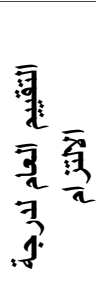 } & \multirow{2}{*}{ 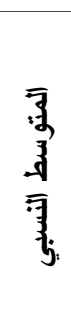 } & \multicolumn{3}{|c|}{ 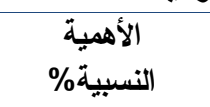 } & \multicolumn{4}{|c|}{ المعايير القيمية (الخلقية، و الروحية، و السلوكية) بأبعادها الفرعية } \\
\hline & & 霓: & 㖣 & 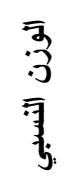 & & & & \\
\hline \multirow{7}{*}{$\begin{array}{l}3 \\
3 \\
3 \\
2 \\
2 \\
1 \\
\vdots \\
2 \\
2\end{array}$} & \multirow{7}{*}{ Vr, r } & $r$ & r & $v r$ & نمو الوازع الايني الخلقي & 1 & \multirow{2}{*}{ 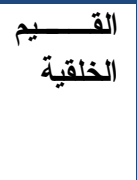 } & 1 \\
\hline & & $\varepsilon$ & م & $V \mu$ & 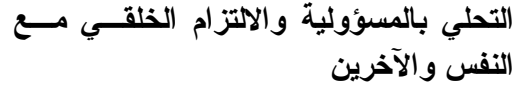 & $r$ & & \\
\hline & & 7 & ق & $v 1, \xi$ & ترسخ العقيدة الإيمانية بالله والأخوة في الله & $r$ & \multirow{2}{*}{ الروحية } & r \\
\hline & & r & r & $V \varepsilon, Y$ & إدراك حقيقة الكون والحياة الإساتية & $\varepsilon$ & & \\
\hline & & 1 & b & $V \varepsilon, \Lambda$ & الاتماء للاين و الوطن و اللغة. & 0 & \multirow{3}{*}{ البلوكية } & $r$ \\
\hline & & 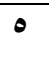 & ق & $\checkmark 1,1$ & الالتزام بالمحددات الثقافية و الفكرية. & 7 & & \\
\hline & & $\mathrm{v}$ & 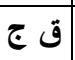 & 71 & احترام القيم والأعر افت و التقاليا الاجتماعية & $\mathrm{v}$ & & \\
\hline متوسط & $r, r$ & & & & 1) & & 1) & \\
\hline
\end{tabular}




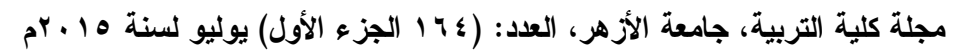

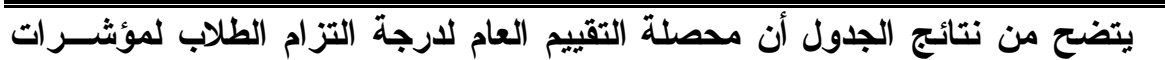

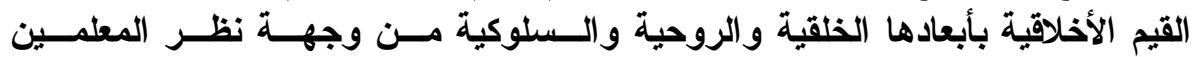

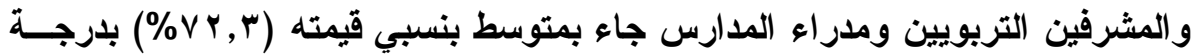

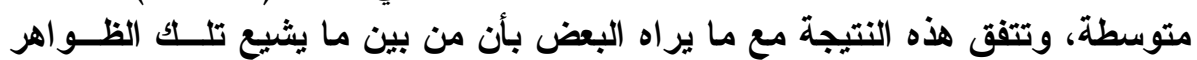

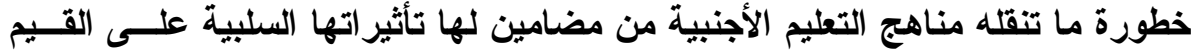

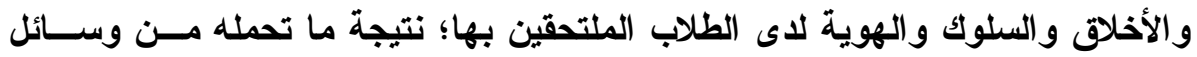

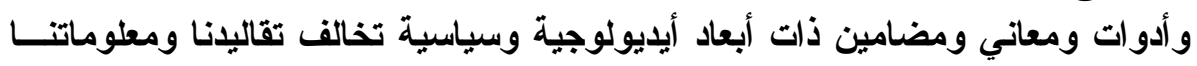

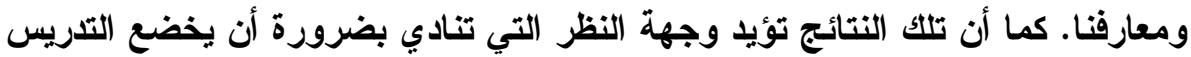

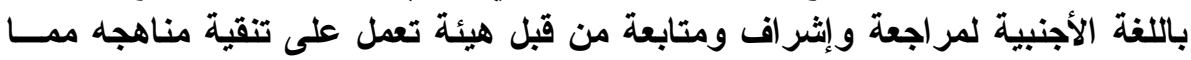

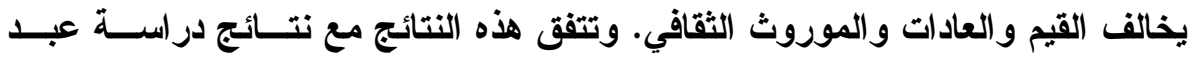

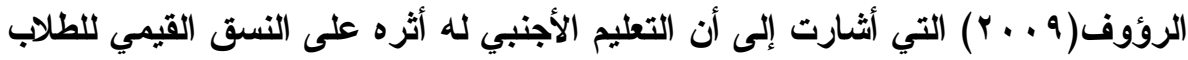

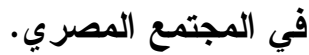
رابعا: إجابة السؤال الرابع. الخاص بـ: ما التوصيات والمقترحات للحد من ســلبيات التعلــيم بــاللغتين العربيــة والاجليزية ذات الأثر في القيم الأخلاقية لطلاب المرحلة الثانوية؟ في ضوء ما سبق عرضه من نتائج البحث، يمكن تقــديم التوصــيات والمقترحسات

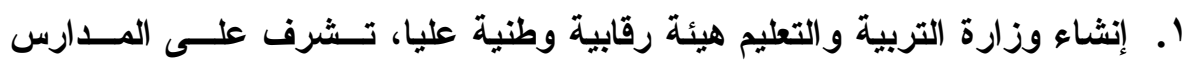

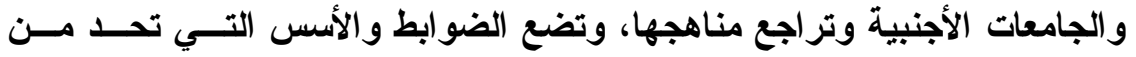

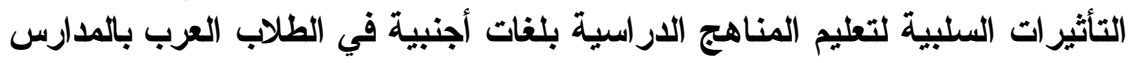

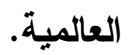

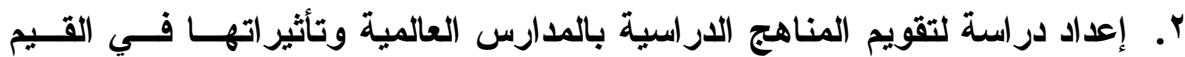

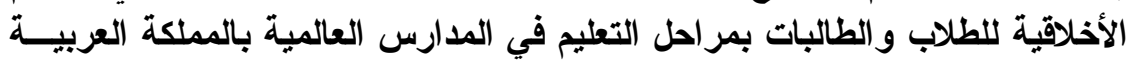

r. تأكيد أهمية تدريس المناهج الدراسية للطلاب العرب باللغة العربيـة، وممارســة

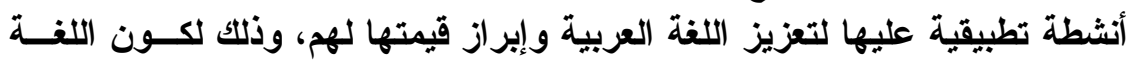

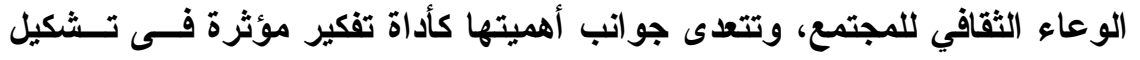

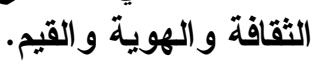

؛. ينبغي التأكيد على أن اللغة الأجنبية المستخدمة في التدريس بالمـــــارس العالميــة

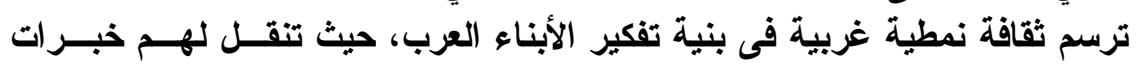


ومصطلحات اشتقت من الثقافة الإنجليزية التي تتغاير في العديد من مضامينها عن ثقافتنا العربية.

•. الاتفات إلى ما يحدثه التدريس بلغات أجنبية من تأثيرات لغوية فئوية اجتماعيـة سلبية منها نحن وهم.

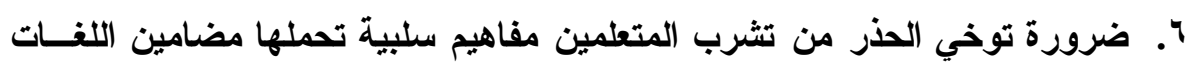
الأجنبية لهم فى طياتها، والتى تستمر تأثير ها بأذهانهم طيلة حياتهم.

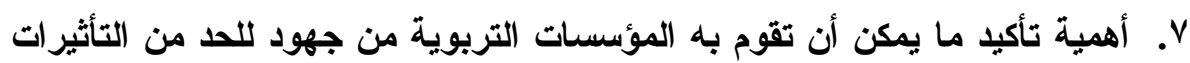

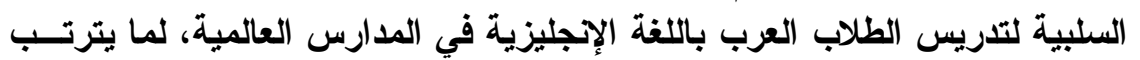

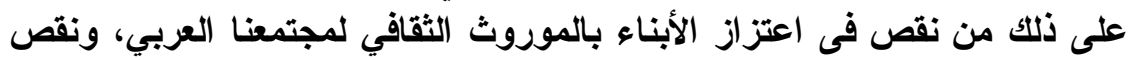

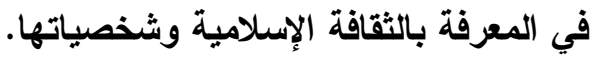
^. أهمية إجراء المزيد من الدراسات التخصصية والمشاريع البحثية على المسستوى

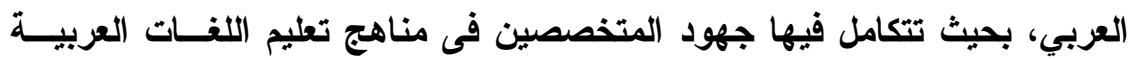

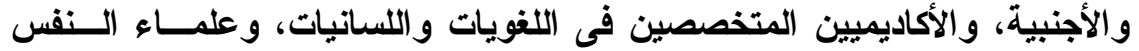

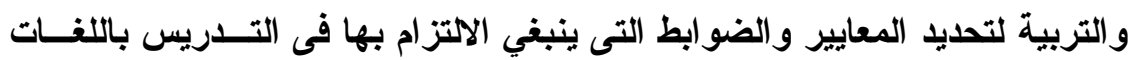

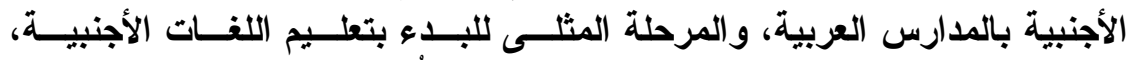

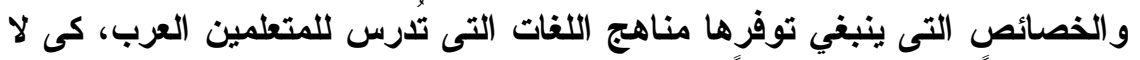

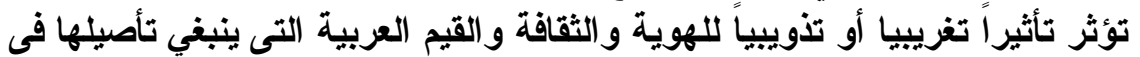
نفوس الناشئة.

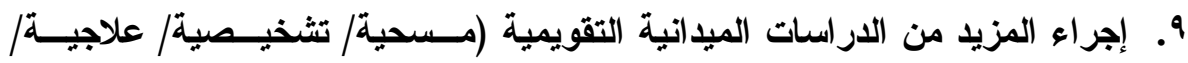

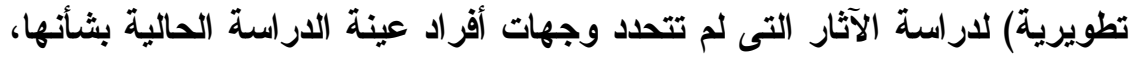

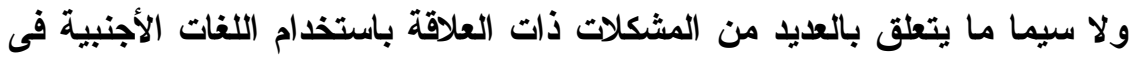

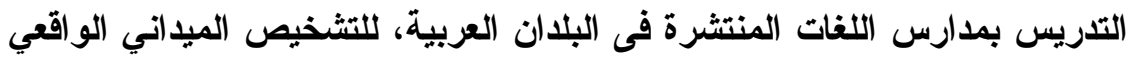
لها، ووضع الآليات المثلى لمواجهتها.

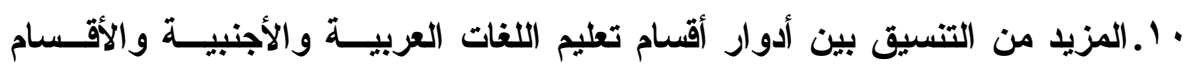

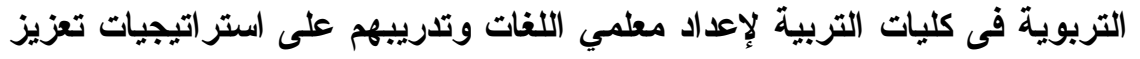

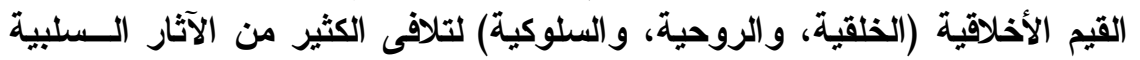
الناتجة عن التذريس باللغات الأجنبية للطلاب العرب في الرية المدارس العالمية.

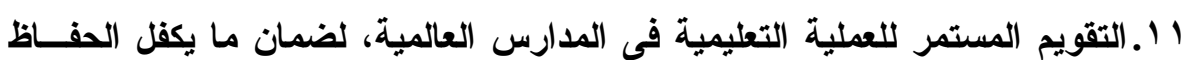

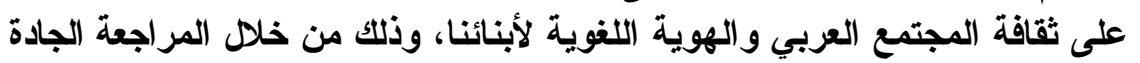

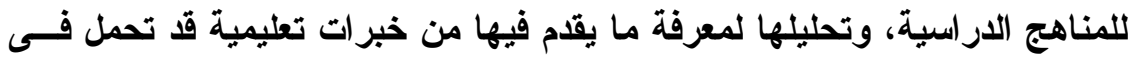




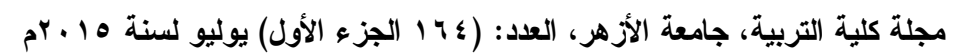

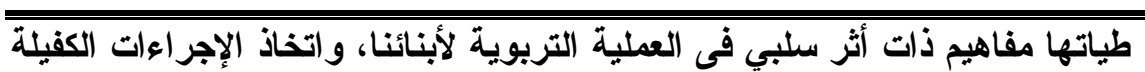

لتجنب تلك التبعات السلبية.

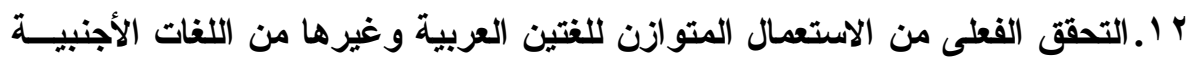

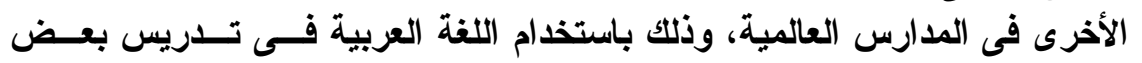

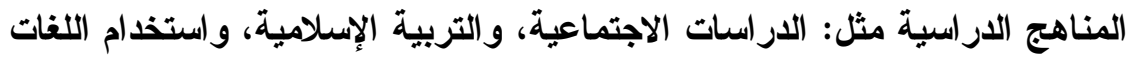
الأجنبية فى دراسة العلوم، و الرياضيات ولاتئن الحاسوب.

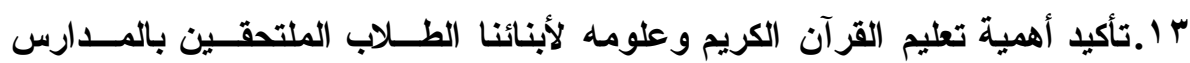

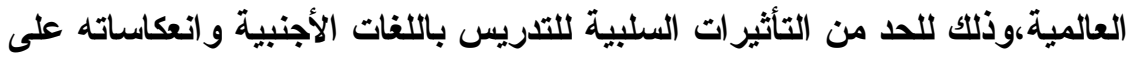

ثقافة أبنائنا ولغتهم وقيمهم الأخلاقية.

ـ ا. بذل المزيد من الجهود لتوعية أولياء الأمور بضرورة انتقاء المدارس العالميــة

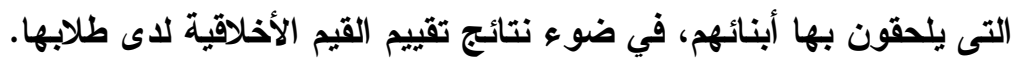

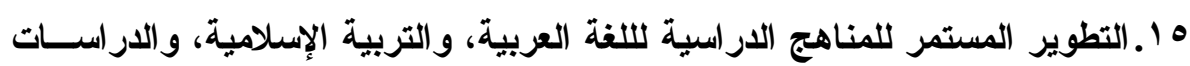

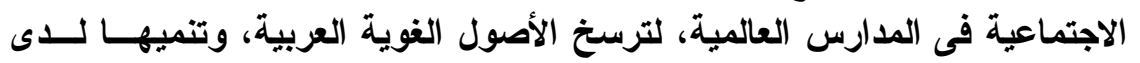

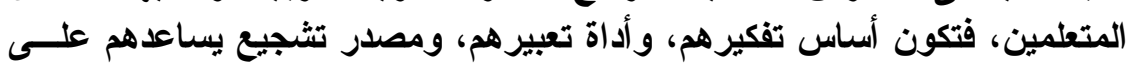
إطلاق ألسنتهم باللغة العربية في كافة نشاطاتهم اليومية.

17

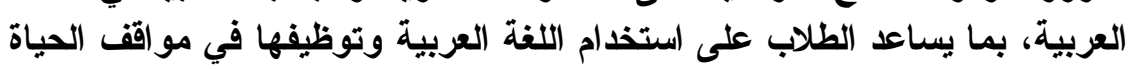

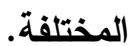

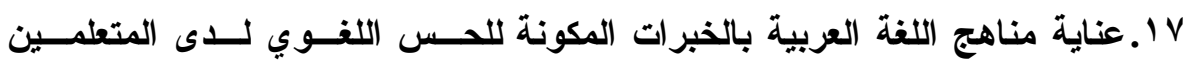
الملتحقين بالمدارس العالمية منذ بداية التحاقهم به في المدرسة الابتدائية.

1 ا.تضمين المناهج الدراسية للغة العربية والدراسات الاجتماعية مضامين تربط المتعلم

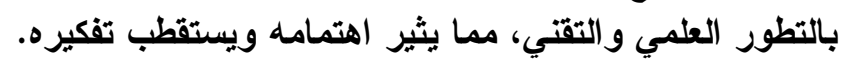

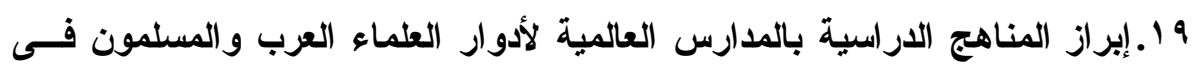
نشأة العلوم المختلفة، وكافة المعارف التى خدمت الإنسانية.

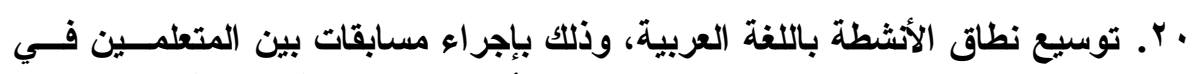

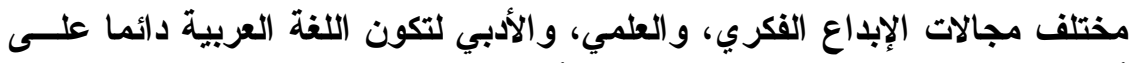
ألسنتهم، وفى عقولهم، ووجدانهم، وذات أثر فاعل في تنمية قيمهم الأخلاقية.

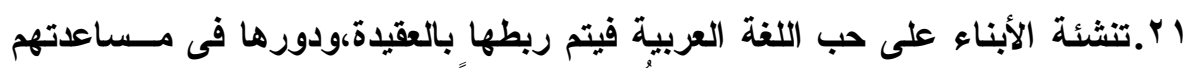

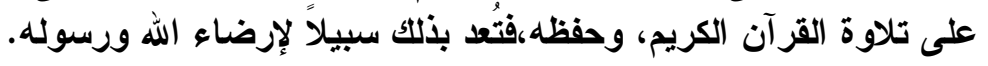




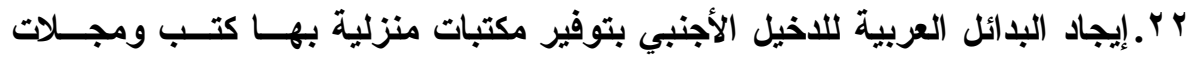

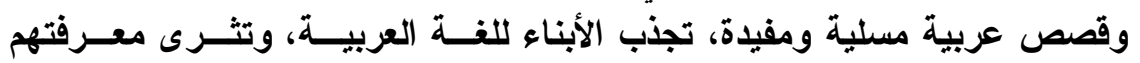

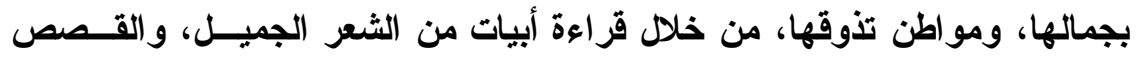

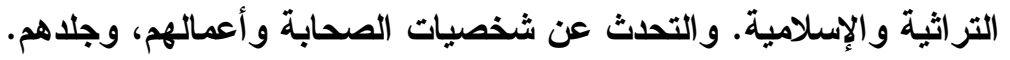

rr.تقديم ما يبث ويشجع على متابعة الجديد في مجال العلم والتقنية بصورة صــافية ومحببة للمتعلمين في الوطن العربي.

؟ ؟.تقديم بر امج بأساليب محببة للغة العربية، من خلا قصص قصيرة هادفة، وأخبار طريفة.

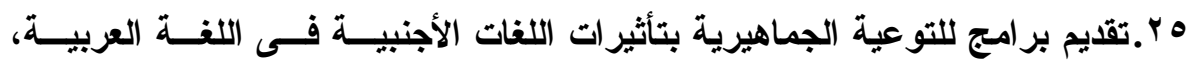

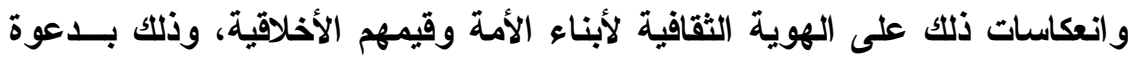

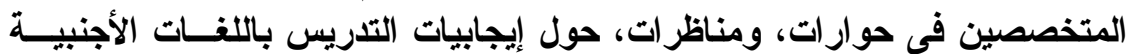

$$
\text { وسلبياتها. }
$$

؟Y.تأكيد أهمية أدوار الهيئات المشرفة على مدارس اللغات فى حمايــة أبنــاء الأمسـة

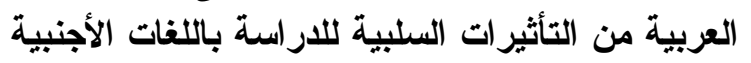

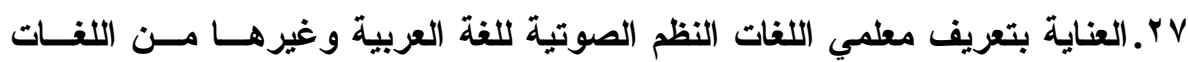

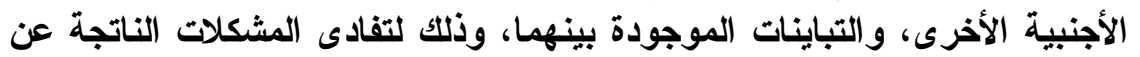

عدم الإلمام بالاختلافات بينها.

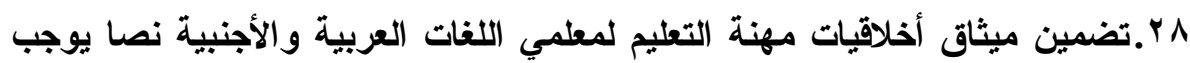
عنايتهم بتعليم اللغة العربية أثناء تأديتهم رسالتهم التعليم لمعليمية. 


\section{خامسا: خاتمة البحث}

وبعد استعرض ما تم التوصل إليه من نتائج للبحث، وما تم اقتراحه من توصيات

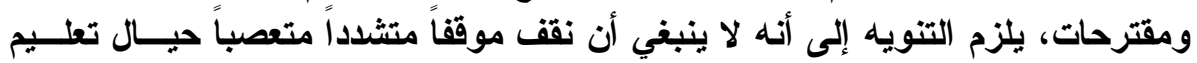

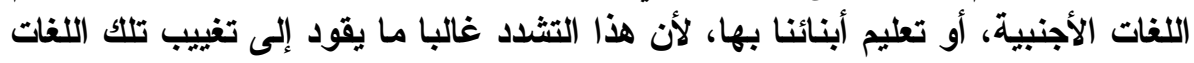

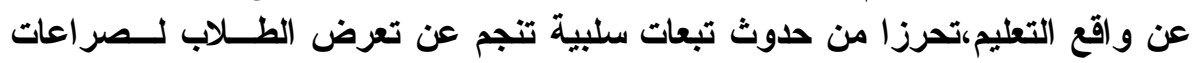

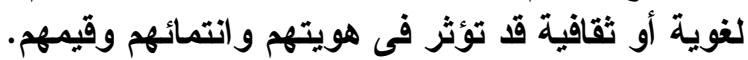

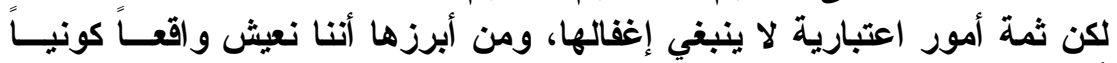

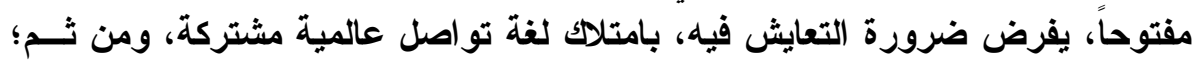

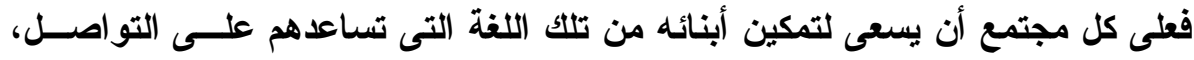

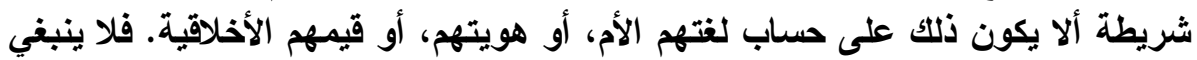

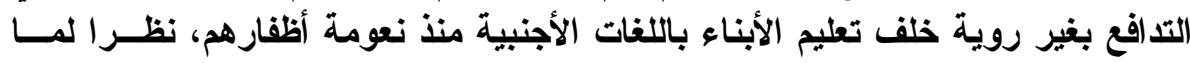

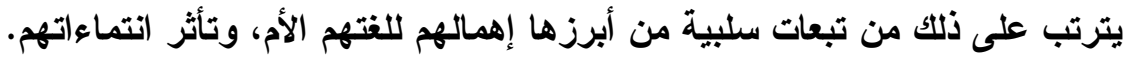

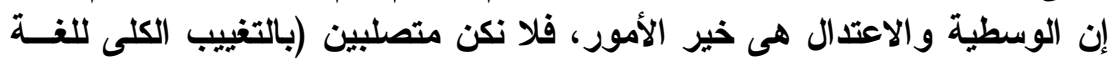

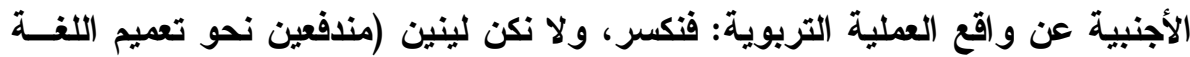

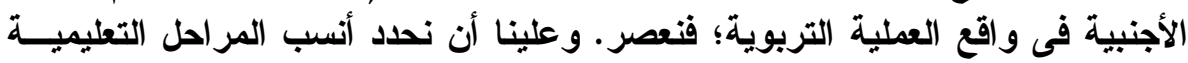

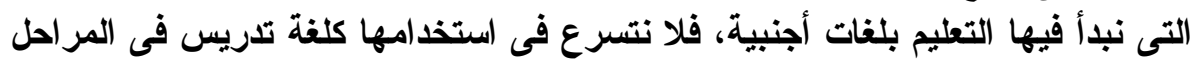

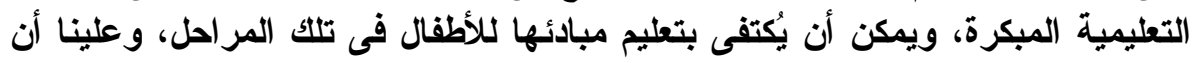

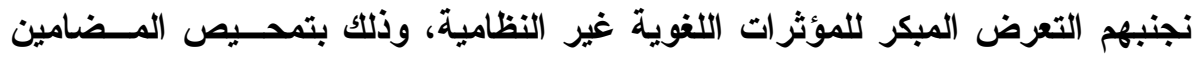

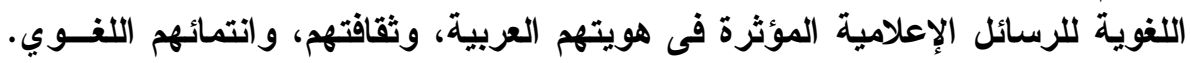
وقيمهم الأخلاقية.

وثمة ضرورة لتجنيب هؤلاء الصغار التبعات السلبية لتعاملهم مع العمالة الأجنبية

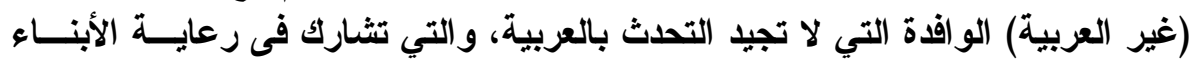

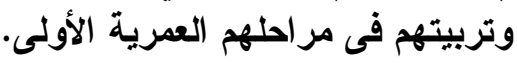

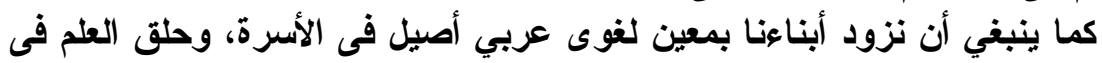

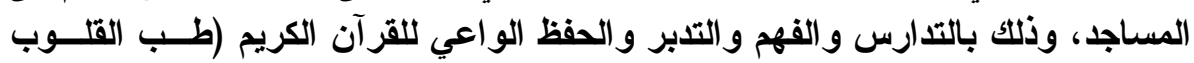
وشفاء الصدور). 
مصادر البحث ومر اجعه

$$
\text { - - - القرآن الكريم }
$$

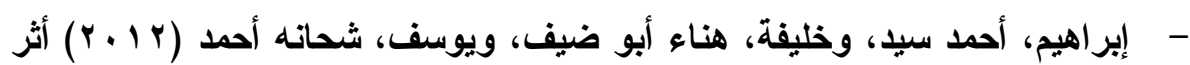

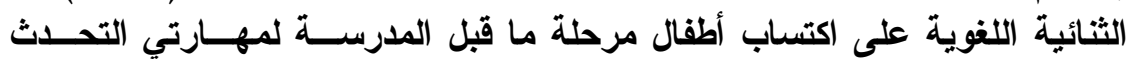

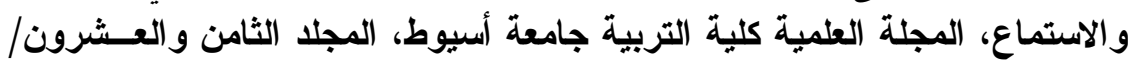

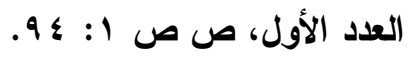

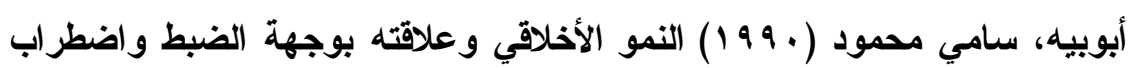

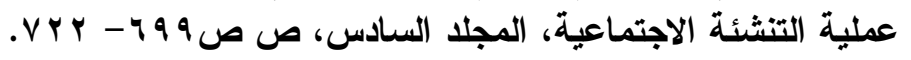

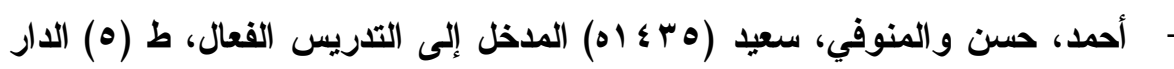
الصولتية للتربية، الرياض.

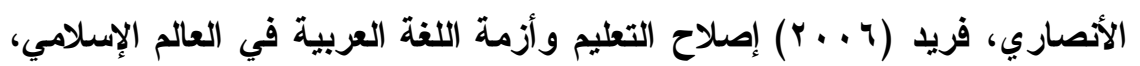

http://albayan-magazine.com/Dialogues/12.htm ندوات البيان،

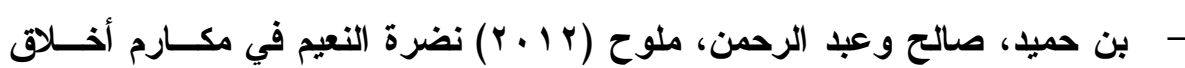

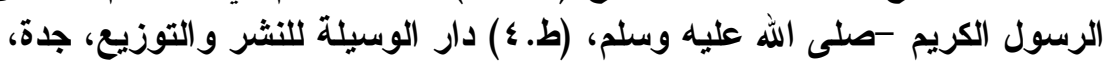

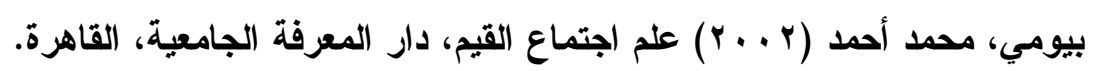

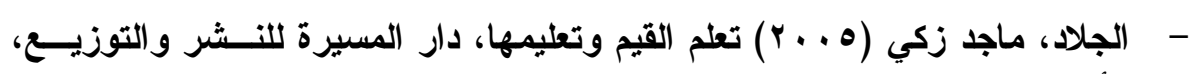

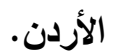

- - الجندي، أنور (9^^191) على طريق الأصالة، اللغة العربية في مواجهــة اللغــات الأجنبية، القاهرة، أنور دار الاعتصام.

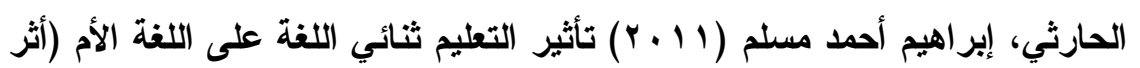

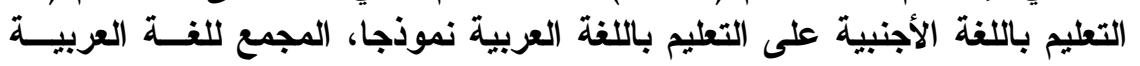

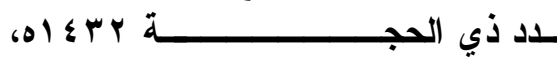
الأردنـ http://www.majma.org.jo/majma/index.php/2009-02-10-09-3528/466-2012-04-23-07-35-32.html

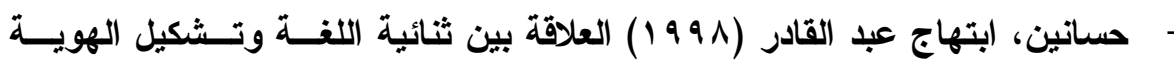

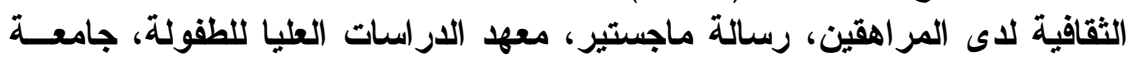
عين شمس.

حسين، مصطفى (1991) أطفالنا ومدارس اللغات الأجنبيــة، مجلــة البيــان، ع ع (r Y I )، الرياض. 


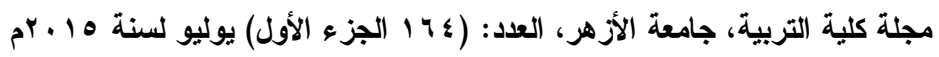

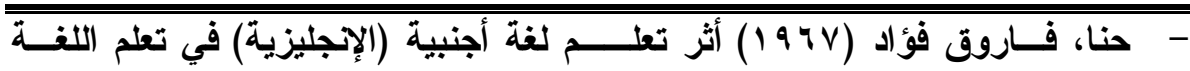

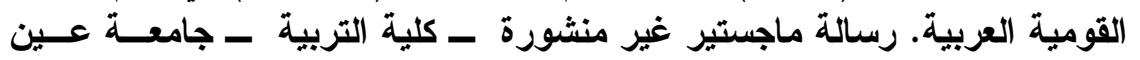

شمس.

- - الخولي، محمد (9911) الحياة مع لغتين، جامعة الملك سعود، الرياض.

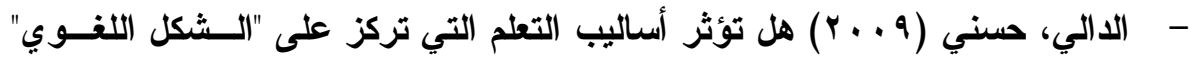

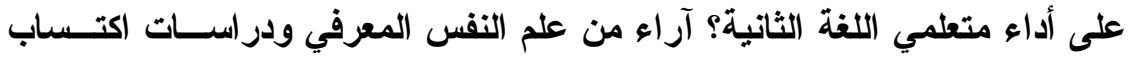

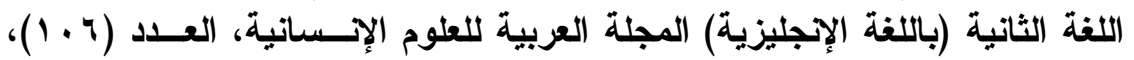

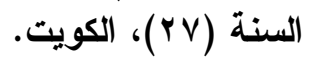

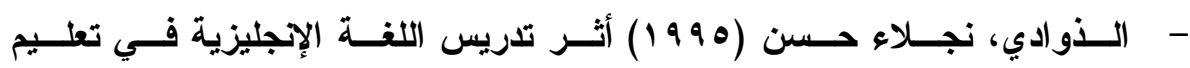

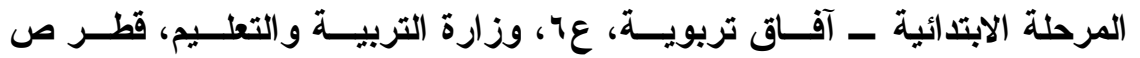

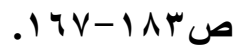

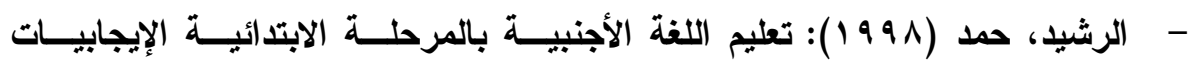

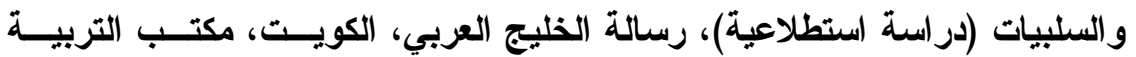

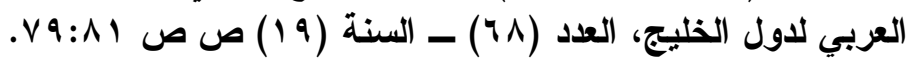

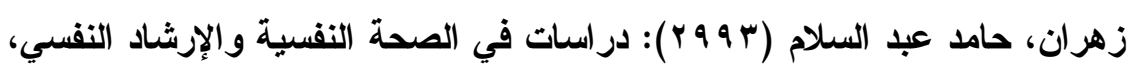

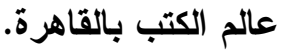

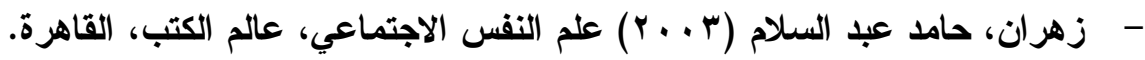

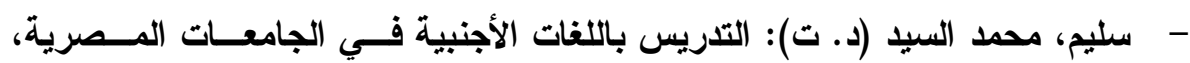
جامعة القاهرة، ملية الاقتصاد والعلوم التوريل السياسية.

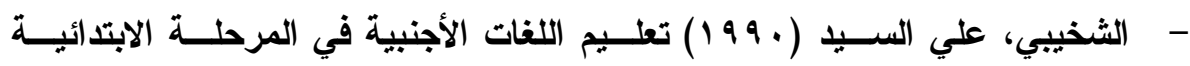
وبعض قضايا مجتمعنا المعاصر ـ كلية التربية ـ جامعة السلطان قابوس، سلطنة عمان.

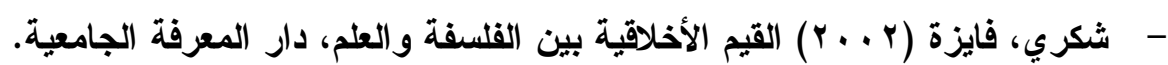

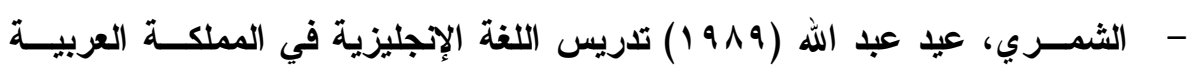

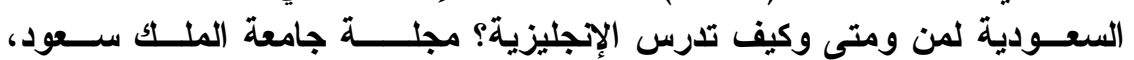

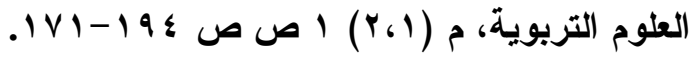
- - طعيمة، رشدي أحمد (991 (1)): الأسس العامة لمناهج تعليم اللغة العربية، إعدادها تطويرها تقويمها، القاهرة: دار الفكر العربي. 


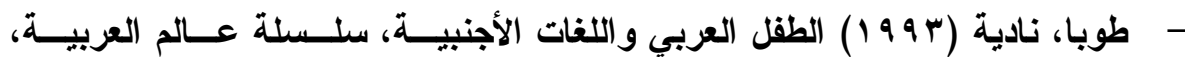

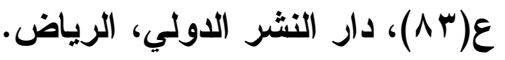

- - الظقيري، محمد دهيم (999 199 ) الثنائية اللغوية وأثرها على الثنائي، مجلة التربية،

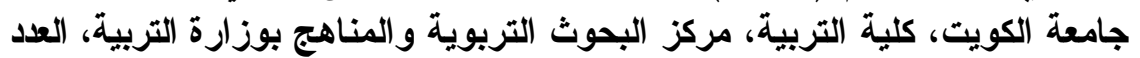

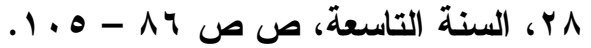

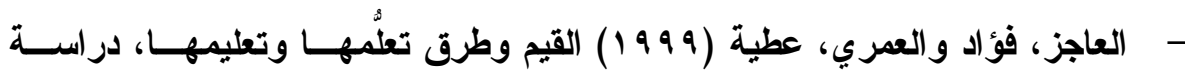

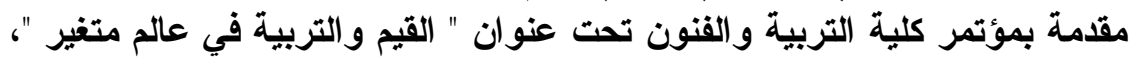

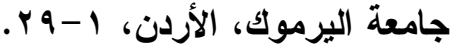

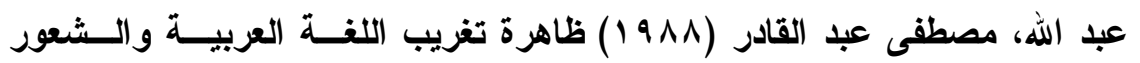

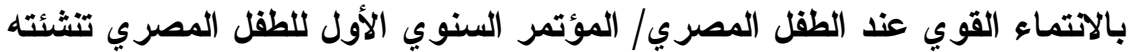

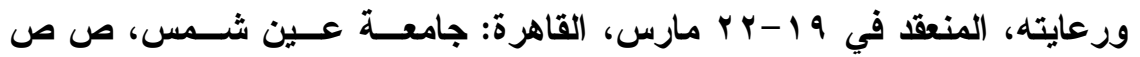
$. r q \vee-r \wedge 1$

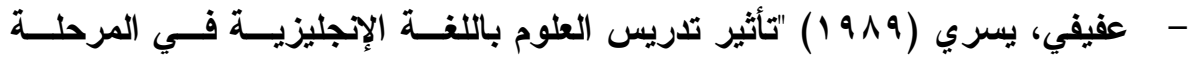

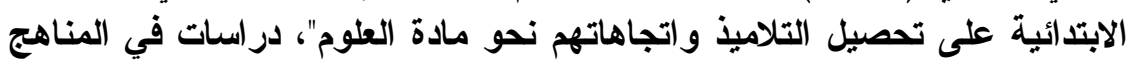
وطرق التدريس، الجمعية المصرية للمناهج وطرق التهن التدريس، القاهرة. - علي، نبيل (\$ 9 9 1) العرب وعصر المعلومات، عالم المعرفة، المجلـس الــوطني

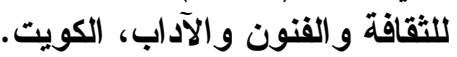

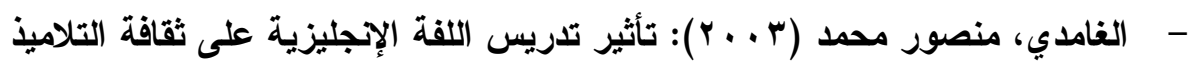
ولغتهم الأم في المرحلة الابتدائية

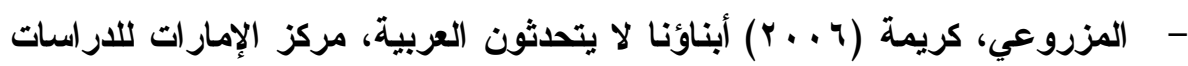
و الإعلام، دبي.

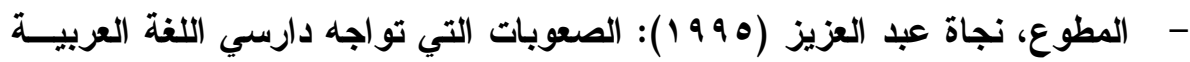

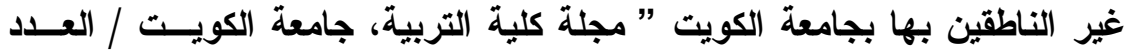

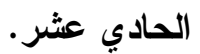

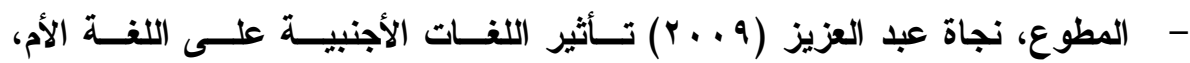
http://www.acmls.org/MedicalArabization/10thIssue/mj1064.h - - نايف خرما، وعلي حجاج(9 1911) اللغات الأجنبية: تعليمها وتعلمهــا: طا، عـالم

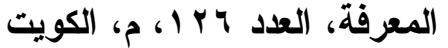


مجلة كلية التربية، جامعة الأزهر، العلد: (ع 17 الجزء الأول) يوليو لسنة 1 ا بام

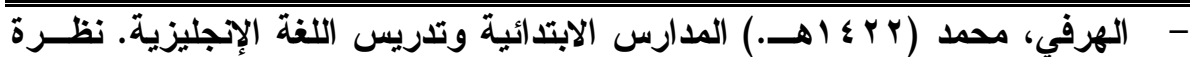

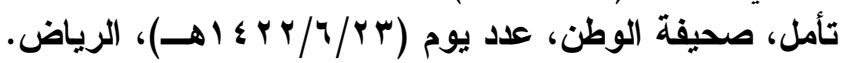

- Elazmi, MeznahSaad Khaled (2011) the Effectiveness of Bilingual School ; The State of Kuwait, Diva sat, Educational Sciences, Volume 38, Supplement 6.

- Hornby, A., Cowie, A. and Gimson, A.( 1984) Oxford Advanced Learner's Dictionary of Current English, 3 ed, Oxford University Press, p 276-337.

- Lynch, S. (2001) "Science for All ... Linguistic and Cultural Diversity", journal of Research in Science Teaching, Vol. 38. No. 5, pp. 622-627

- Reinhard, B.(1996) "How medium of Instruction Affect the Learning "School Science Review, Vol. 78. No. 238, pp. 7378

- Shinn, M. (1998) Advanced Application of Curriculum Based Measurement, The Guilford press, New York, USA.

- UNESCO (1997) Working Documents of Intergovernmental Conference on Language policies in Africa, Paris, UNESCO, p. 8. 


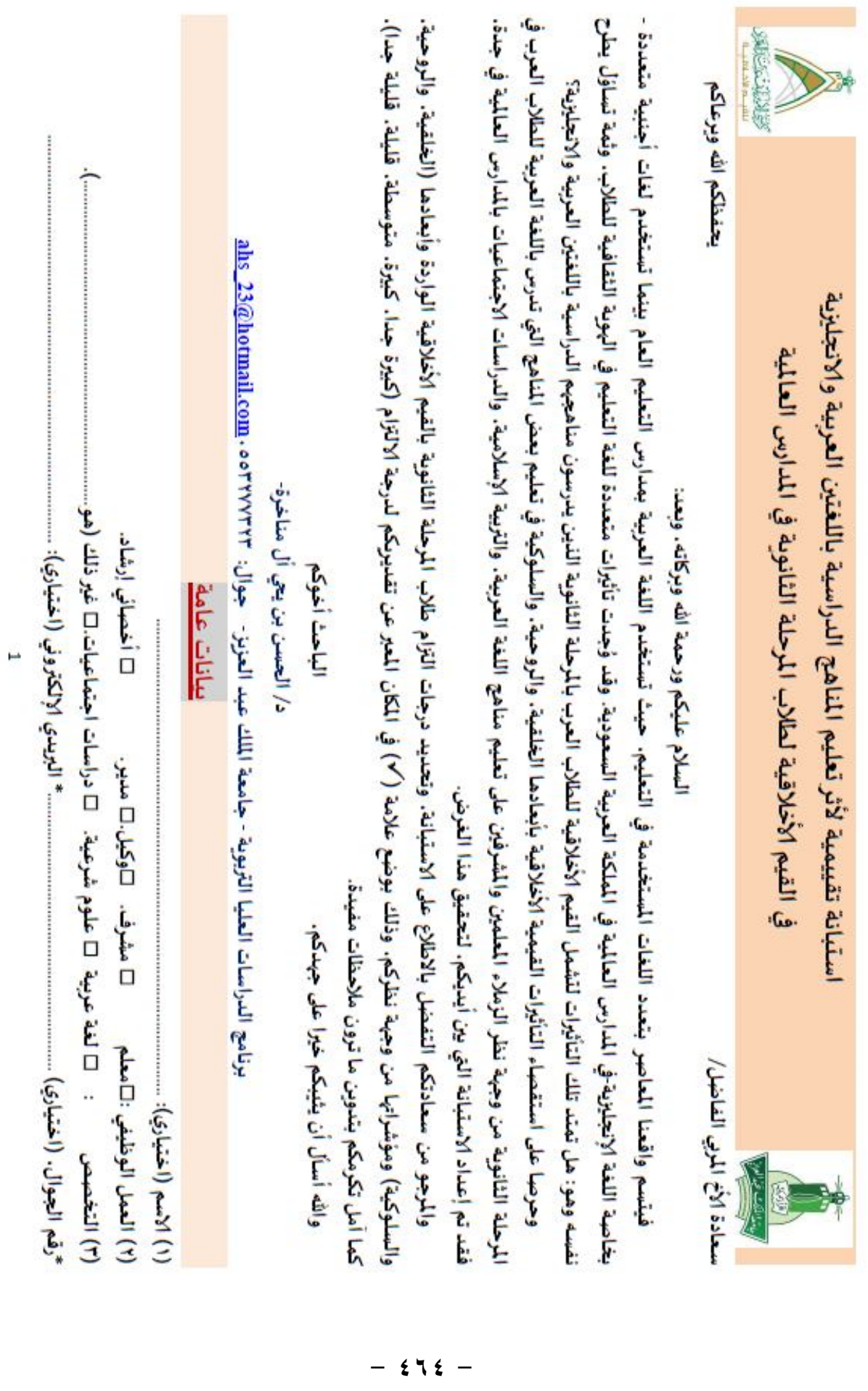




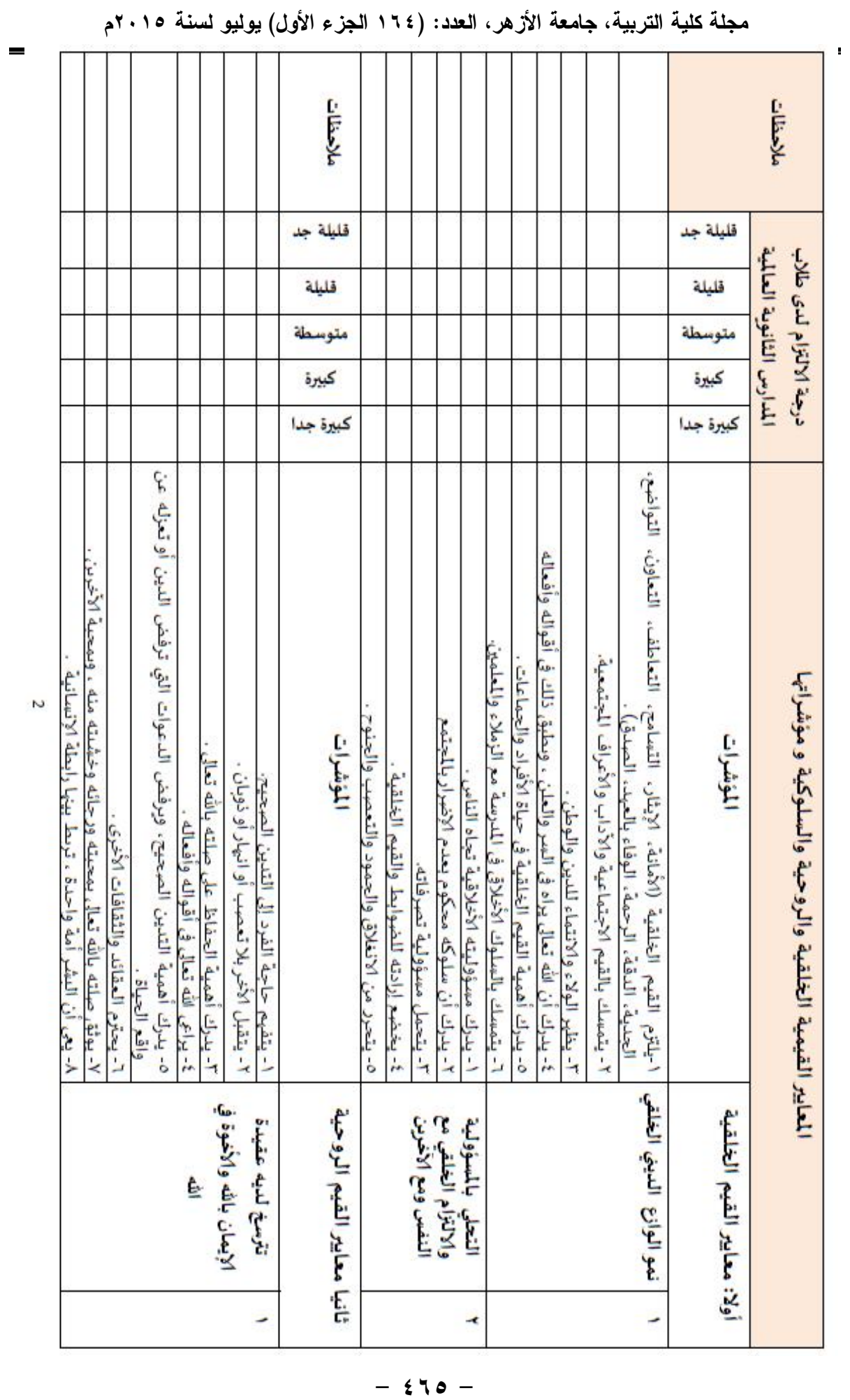


مجلة كلية التربية، جامعة الأزهر ، العلد: (ع 17 الجزء الأول) يوليو لسنة ه 1 بام

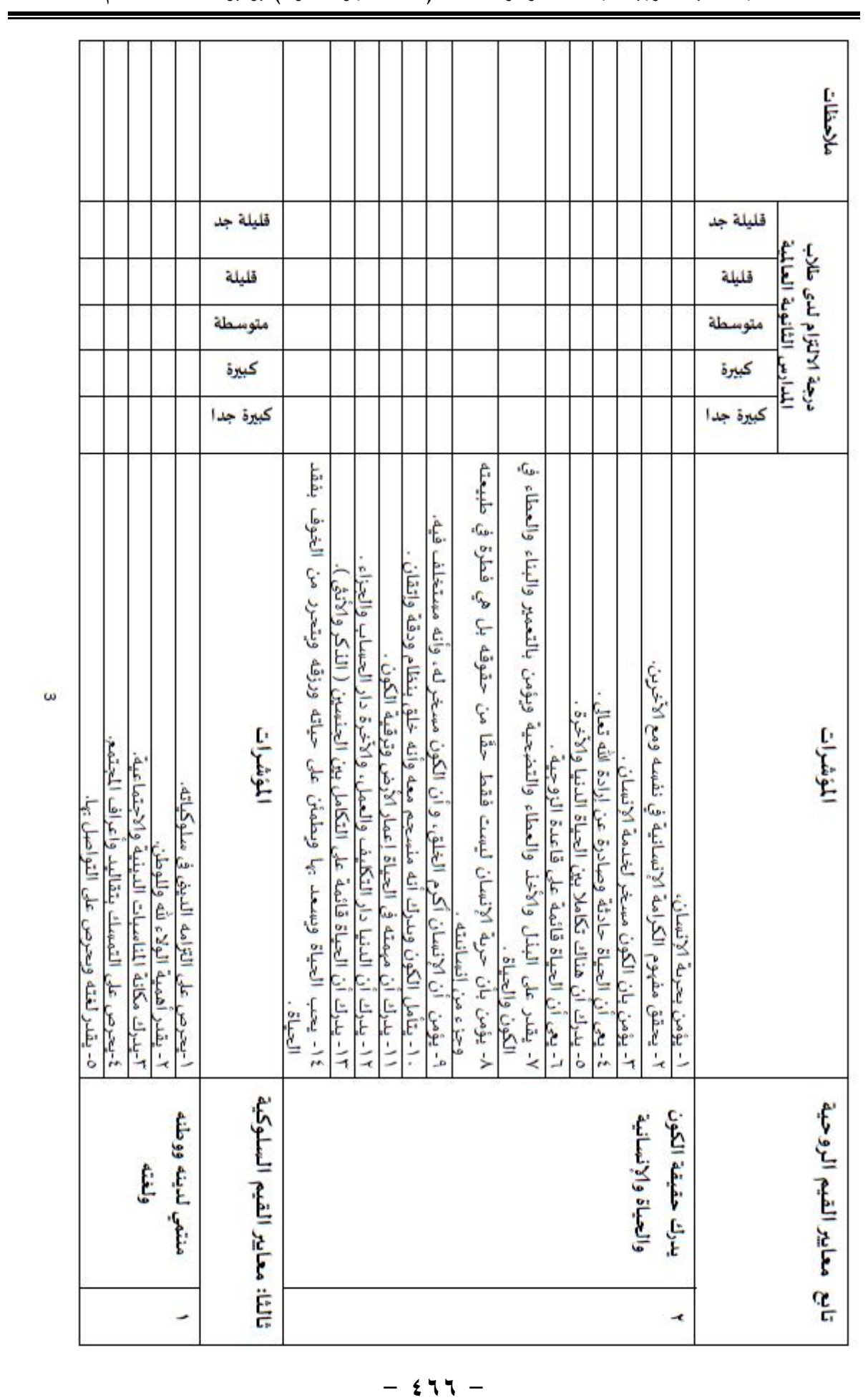




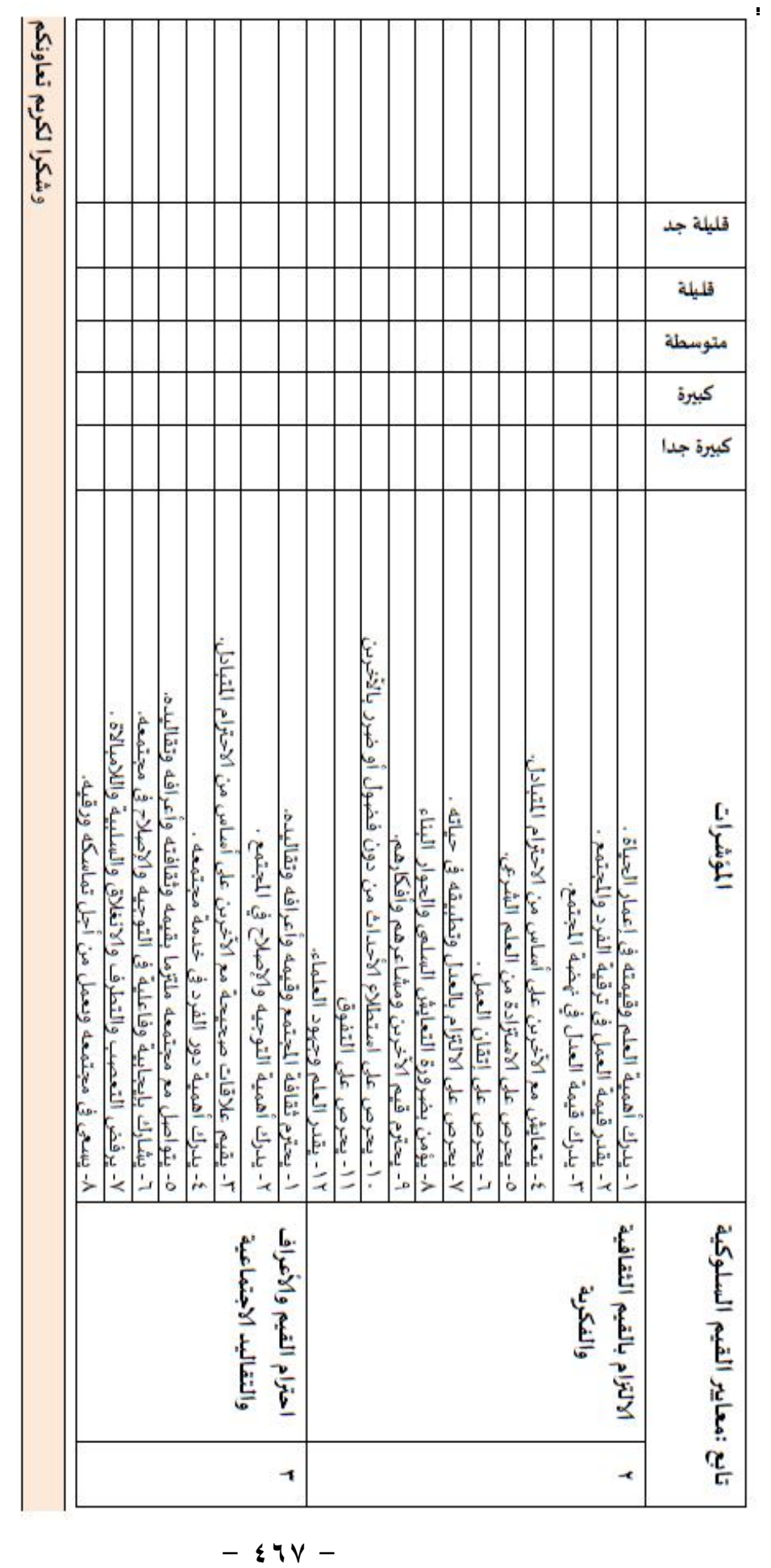

